\title{
Activins and Inhibins: Roles in Development, Physiology, and Disease
}

\author{
Maria Namwanje ${ }^{1}$ and Chester W. Brown ${ }^{1,2,3}$ \\ ${ }^{1}$ Department of Molecular and Human Genetics, Baylor College of Medicine, Houston, Texas 77030 \\ ${ }^{2}$ Department of Pediatrics, Baylor College of Medicine, Houston, Texas 77030 \\ ${ }^{3}$ Texas Children's Hospital, Houston, Texas 77030 \\ Correspondence: cbrown@bcm.edu
}

Since their original discovery as regulators of follicle-stimulating hormone (FSH) secretion and erythropoiesis, the TGF- $\beta$ family members activin and inhibin have been shown to participate in a variety of biological processes, from the earliest stages of embryonic development to highly specialized functions in terminally differentiated cells and tissues. Herein, we present the history, structures, signaling mechanisms, regulation, and biological processes in which activins and inhibins participate, including several recently discovered biological activities and functional antagonists. The potential therapeutic relevance of these advances is also discussed.

\section{INTRODUCTION, HISTORY AND NOMENCLATURE}

$T_{\mathrm{m}}^{\mathrm{h}}$ he activins and inhibins are among the 33 members of the TGF- $\beta$ family and were first described as regulators of follicle-stimulating hormone (FSH) secretion and erythropoiesis. However, activins and inhibins have since been implicated in a variety of biological processes, ranging from the early stages of embryonic development, to highly specialized functions in terminally differentiated cells and tissues ( $\mathrm{Yu}$ et al. 1987; Vassalli et al. 1994; Matzuk et al. 1995c; Aono et al. 1997; Yamaoka et al. 1998; Molloy et al. 1999; Munz et al. 1999a). Herein, we provide an overview of the history, protein structures, signaling mechanisms and their regulation, and the many biological processes in which the activins and inhibins participate, representing some of the most fascinating aspects of TGF- $\beta$ family biology. We will also incorporate new biological activities that have been recently discovered, the potential clinical relevance of these advances, and therapeutic challenges.

The activins and inhibins comprise integrally linked components of the TGF- $\beta$ family. The activins were originally recognized for their abilities to augment the gonadotropin-releasing hormone $(\mathrm{GnRH})$-mediated release of FSH, and were named "activins" because their effects were functionally opposite to those of inhibin in this context (Ling et al. 1986a; Vale et al. 1986). Activins also augment erythropoietin (EPO)-dependent hemoglobin production in K562 erythroleukemia cells and enhance the proliferation of erythrocyte precursors from

Editors: Rik Derynck and Kohei Miyazono

Additional Perspectives on The Biology of the TGF- $\beta$ Family available at www.cshperspectives.org

Copyright (C) 2016 Cold Spring Harbor Laboratory Press; all rights reserved

Advanced Online Article. Cite this article as Cold Spring Harb Perspect Biol doi: 10.1101/cshperspect.a021881 
human bone marrow cells (Eto et al. 1987; Yu et al. 1987).

Inhibins and activins share common $\beta$ subunits, with inhibins occurring as $\alpha \beta$ heterodimers, whereas activins are $\beta \beta$ homodimers. Because inhibins were discovered and isolated before activins, the $\beta$ monomers are designated inhibins $\beta \mathrm{A}$ and $\beta \mathrm{B}$, and the genes are Inhba and Inhbb, respectively. However, the $\beta$ monomers are also often referred to as activins $\beta A$ and $\beta B$, the designations that will be used herein (Fig. 1A). Activins $\beta A$ and $\beta B$ are closely related peptides, showing $63 \%$ identity and $87 \%$ similarity within their mature domains. Activins were identified in eluted fractions from porcine follicular fluid and stimulated FSH secretion in vitro from pituitary gonadotropes, which normally produce FSH and luteinizing hormone $(\mathrm{LH})$. The eluted proteins were heterodimers of activin $\beta \mathrm{A}$ and $\beta \mathrm{B}$ monomers $(\beta \mathrm{A} \beta \mathrm{B}$ ) (Ling et al. 1986b). Homodimers of the $\beta A$ or $\beta \mathrm{B}$ monomers (activins A and B, respectively) also stimulated FSH release (Ling et al. 1986a; Vale et al. 1986; Mason et al. 1989), whereas inhibin heterodimers $(\alpha \beta A$ and $\alpha \beta B$, inhibins $A$ and $B$, respectively) blocked this effect (Setchell and Jacks 1974; De Jong and Sharpe 1976).

Activin $C(\beta C \beta C)$ and activin $E(\beta E \beta E)$ were later identified with predominant expression in liver but also in several other tissues. Activin $\beta C$ and $\beta E$ monomers also have the capacity to heterodimerize among themselves $(\beta C \beta E)$ with other activin monomers and inhibin $\alpha$ (Fang et al. 1996, 1997; Schmitt et al. 1996; O'Bryan et al. 2000; Hashimoto et al. 2002; Vejda et al. 2002; Mellor et al. 2003; Gold et al. 2004; Ushiro et al. 2006). Activins $\mathrm{C}$ and $\mathrm{E}$ are unlikely to signal through activin receptors but rather antagonize activin A signaling by forming $\beta \mathrm{A} \beta \mathrm{C}$ or $\beta \mathrm{A} \beta \mathrm{E}$ heterodimers, as seen in human PC3 prostate tumor cells cotransfected with activins $\beta A$ and $\beta C$ (Mellor et al. 2003) and in transgenic mice that overexpress activin $\beta C$ on an inhibin- $\alpha$-deficient genetic background, thereby mitigating the cancer-cachexia phenotype of Inha ${ }^{-1-}$ mice (Gold et al. 2013). To our knowledge, the ability of activins $\mathrm{C}$ or $\mathrm{E}$ to inhibit activin $\mathrm{B}$ signaling has not been reported.

\section{PROCESSING, STRUCTURE AND SIGNALING}

\section{Processing of Ligands}

Activins are formed when larger pro-proteins dimerize, followed by cleavage to produce two mature $\beta$ monomers, activin $\mathrm{A}$, activin $\mathrm{B}$ or activin $\mathrm{AB}(\beta \mathrm{A} \beta \mathrm{B}$ ) (Ling et al. 1986b; Vale et al. 1986). Dimerization of the $\beta A$ or $\beta B$ peptides with $\alpha$ inhibin (encoded by the Inha gene) followed by cleavage, results in heterodimeric inhibin A and inhibin B, respectively (Fig. 1A) (Antenos et al. 2008). After the pro-proteins are synthesized, the prodomains aid in folding and assembling of their mature peptides, by holding them in a dimerization-competent conformation (Gray and Mason 1990; Walton et al. 2009, 2012). Three amino acids within the inhibin $\alpha$ prodomain (Leu30, Phe37, Leu41) form a hydrophobic interface with the mature peptide, are required for heterodimer assembly and secretion, and are likely to mediate noncovalent interactions with the mature domain (Walton et al. 2009). A similar relationship exists between the activin $\beta$ A pro- and mature domains. $\mathrm{Mu}-$ tation of these key amino acids results in greatly reduced production of activin $\mathrm{A}$ and inhibin $\mathrm{A}$, because of the failure of dimerization. Similar observations have been made for members of other branches of the TGF- $\beta$ family and suggest a possible common paradigm for the prodomains in functional assembly of TGF- $\beta$ family ligands. Also, mutations in the activin $\beta$ A prodomain greatly reduce its capacity to bind the mature domain as well as its ability to inhibit activin A functions (Walton et al. 2009).

Differences in posttranslational glycosylation of the inhibin $\alpha$ subunit substantially affect the production, secretion, and bioactivity of inhibin A and affect its affinity for betaglycan (Mason et al. 1996; Antenos et al. 2007; Makanji et al. 2007). Failure of normal glycosylation in ovarian granulosa cells results in markedly reduced secretion of inhibin $\alpha$ without impacting activin assembly and release. Therefore, reduction of inhibin $\alpha$ secretion is predicted to favor the production of activins more than inhibins, so glycosylation provides a potential mecha- 
A

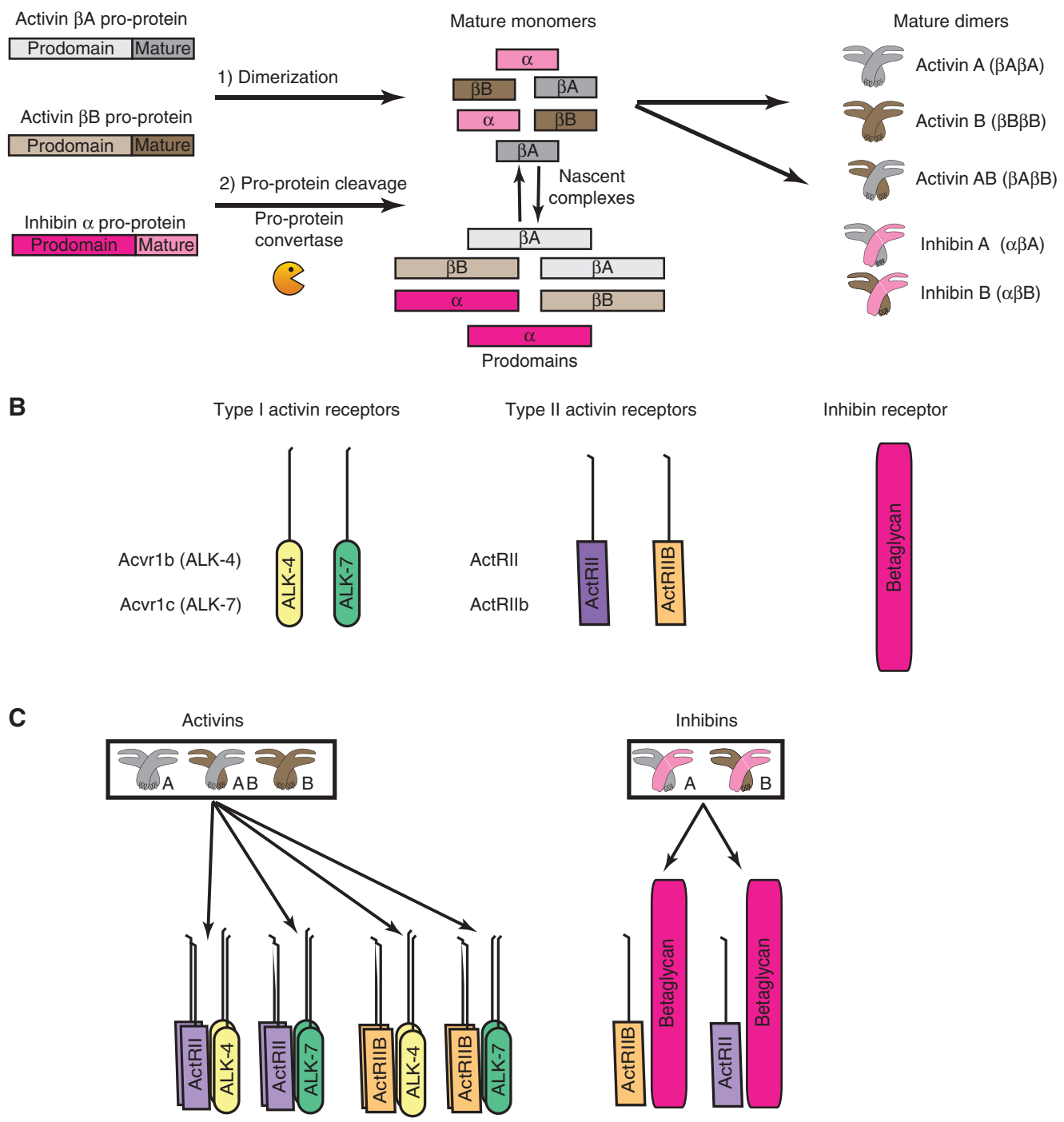

Figure 1. Activin and inhibin ligands and receptors. (A) Activin $\beta$ A, activin $\beta B$, and inhibin $\alpha$ are synthesized as pro-proteins that comprise a prodomain and mature domain. The pro-proteins associate to form homo- or heterodimers, which are ultimately processed into activins $\mathrm{A}, \mathrm{B}, \mathrm{AB}$, and inhibins $\mathrm{A}$ and $\mathrm{B}$. The junctions of the pro- and mature domains are cleaved by pro-protein convertases, resulting in dimer complexes that retain the noncovalently linked prodomains. (B) The two type I receptors for activins are ActRIB (ALK-4) and ActRIC (ALK-7). The two type II receptors are ActRII and ActRIIB. The inhibins antagonize activin signaling by using one type II receptor and one type III TGF- $\beta$ receptor, betaglycan. $(C)$ The mature activin dimers bind type I and type II receptors to form active signaling complexes. Each activin dimer can bind more than one combination of type I and type II receptors with different affinities, and each type I/type II receptor combination can bind different dimers, including other members of the TGF- $\beta$ family. The active signaling complex is comprised of one activin dimer, two type I, and two type II receptors. Inhibins competitively antagonize activin signaling by binding one type II receptor and betaglycan, thereby sequestering type II receptors in an inactive complex. 
M. Namwanje and C.W. Brown

nism to control the relative levels of activins and inhibins in cells in which they are coexpressed.

After the cleavage by convertases, the proand mature domains remain associated through noncovalent interactions (Antenos et al. 2008, 2011). Activins and inhibins are secreted from the cell in this fashion, protecting the nascent mature dimers from extracellular degradation (Fig. 2A-C) (Gray and Mason 1990). The prodomains interact extracellularly with specific components of the extracellular matrix, perlecan and agrin, by binding to their heparan sulfate side chains (Fig. 2D) (Li et al. 2010), thereby protecting the activins and inhibins from proteolysis, and perhaps presenting them at higher concentrations to their receptors. Binding of the mature dimers to their receptors displaces the prodomains (Fig. 2E) (Walton et al. 2009).

\section{Structure of Ligands}

The structures of activin A alone and in combination with activin receptor type IIB (ActRIIB) are represented in Figure 3 (Thompson et al. 2003; Greenwald et al. 2004). Key elements include the "open hand" or "butterfly-like" configuration of the activin dimer, the "finger-like" and "wrist" domains, comprised of a pair of anti-parallel $\beta$-sheets and an $\alpha$-helix, respectively, and a cystine knot-core (Fig. 3A). The "finger" and "wrist" domains interact with type II and type I receptors, respectively. The amino acids required for these interactions have been determined (Fig. 3B).

The interactions with the type I receptors are inferred from prototypic structural data and site-directed mutagenesis. The activin dimer interacts with the ActRIIB dimer through the convex surfaces of the ligand finger regions and concave surfaces of each of the type II receptors. The interactions are mediated by specific ionic/polar and hydrophobic amino acids (Greenwald et al. 1999; Gray et al. 2000). Activin binding to the type II receptors stabilizes the receptors within the cell membrane. The flexibility of the bound ligand allows it to interact with two type I receptors that bind hydrophobic pockets formed by the activin dimer. The type I receptors are subsequently phosphorylated at their glycine-serine-rich (GS) domains. The phosphorylation activates the type I receptor kinase, resulting in the phosphorylation of downstream signaling components (Harrison et al. 2003; Greenwald et al. 2004; Tsuchida et al. 2004). Differences in specific amino acids of activins $\beta \mathrm{A}$ and $\beta \mathrm{B}$ that affect binding to type II receptors likely explain why activin A binds with higher affinity and has greater biopotency in most contexts (Mathews and Vale 1991; Del Re et al. 2004). The cases in which the bioactivity of activin B is greater (e.g., in pancreatic islet cells) are likely because of the use of the other type I activin receptor, ALK-7 (Tsuchida et al. 2004; Bertolino et al. 2008).

The crystal structure of inhibin has not been determined; however, some aspects can be inferred because the structure of the $\beta$ subunit and critical regions for the prototypical ligand/receptor interactions are known. Mammalian inhibin $\alpha$ has several additional amino acids at its amino terminus that are not present in other TGF- $\beta$ family members, and lacks the $\alpha$-helical configuration in the "wrist" domain. Instead, the "wrist" region contains a prolinerich sequence that not only disrupts the helix, but also facilitates the interaction with betaglycan (Makanji et al. 2008; Zhu et al. 2010).

\section{Signaling in Response to Ligands}

Several extra- and intracellular events influence activin signaling (Fig. 4). Strict control is necessary because dysregulated signaling has adverse effects in vivo and at the cellular level (Matzuk et al. 1992; Schwall et al. 1993; Tanimoto et al. 1999; Chen et al. 2000).

\section{Activin Receptors}

Like other members of the TGF- $\beta$ family, signaling of dimeric activins occurs through two type I and two type II serine-threonine kinase receptors (Fig. 1B,C) (Mathews and Vale 1991; Mathews et al. 1992; Cárcamo et al. 1994; Attisano et al. 1996). Each of the seven type I receptors has an additional activin receptor-like kinase (ALK) designation. The type I receptors for the activins are ActRIB and ActRIC (ALK-4 


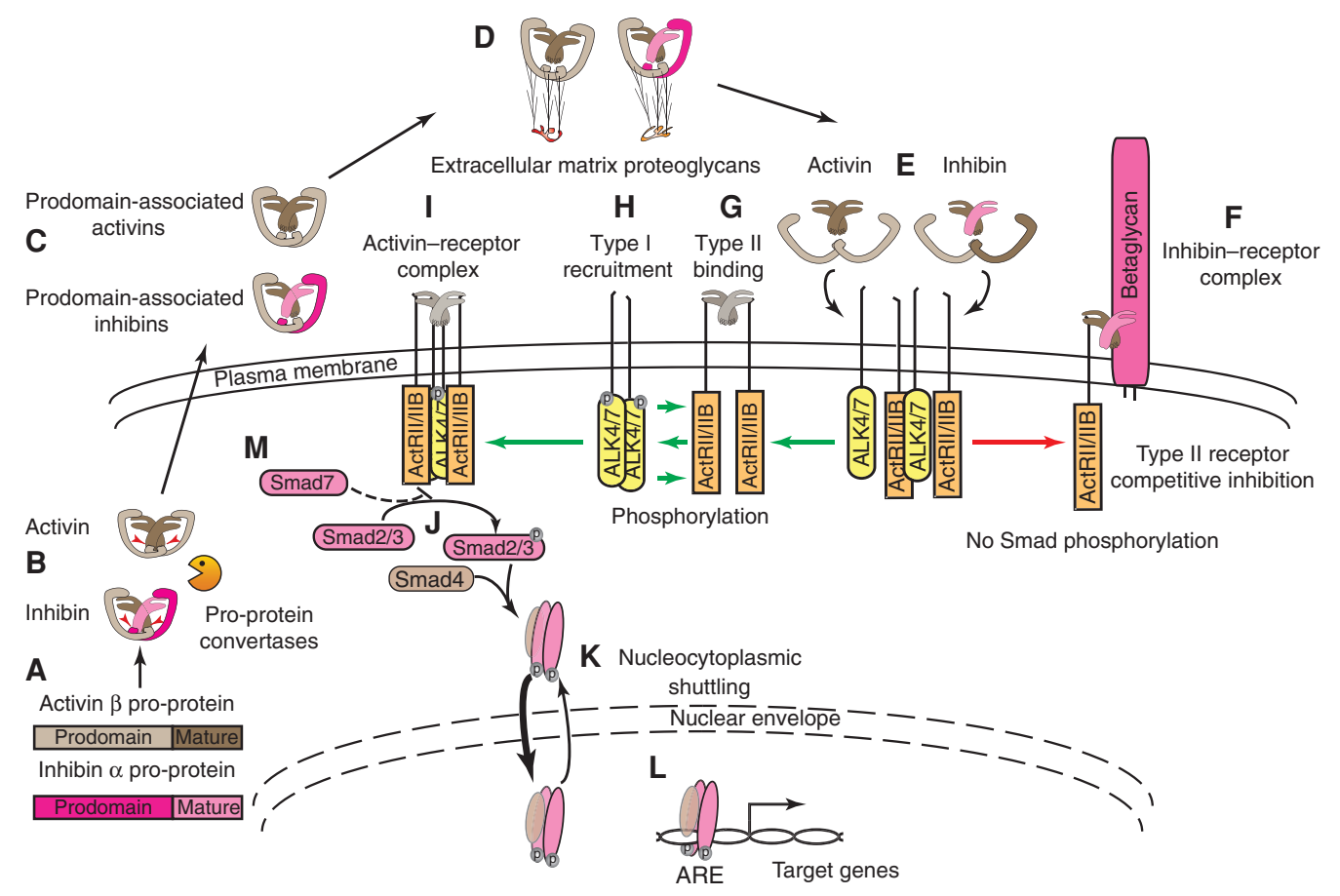

Figure 2. Activin and inhibin processing and signaling. (A) Activin and inhibin monomers are synthesized as pro-proteins. $(B)$ The pro-proteins associate as homodimers or heterodimers with their intact prodomains. Within the cell, the junctions of the pro- and mature domains (red arrowheads) are cleaved by pro-protein convertases, leaving the noncovalent interactions among the domains intact. $(C$ ) Prodomain-associated activins and inhibins are released from the cell. $(D)$ The intact prodomains enable interactions with glycosaminoglycans on proteins within the extracellular matrix. (E) Activins and inhibins compete for type I and II activin receptor binding, and, on receptor binding, release their associated prodomains. $(F)$ Inhibin antagonizes activin signaling through association of its single inhibin $\beta$ subunit with a single type II activin receptor and the association of its single inhibin $\alpha$ subunit with the membrane proteoglycan, betaglycan, thereby forming an inactive inhibinreceptor complex. This complex is incapable of signal transduction and thus inhibits activin signaling by sequestering type II activin receptors (red arrow). $(G)$ The activation of activin receptors requires several steps (green arrows). The activin dimer binds two type II activin receptors, and activates type II receptor serinethreonine kinase activity. $(H)$ Type II receptor binding results in recruitment and association with two type I activin receptors, ActRIB (ALK-4) or ActRIC (ALK-7), that are subsequently phosphorylated. $(I, J)$ The fully assembled, hexameric ligand-receptor complex then initiates Smad-mediated signaling by phosphorylating regulatory Smad2 and/or Smad3 (Smad2 and Smad3) near their carboxyl termini, followed by association of two phosphorylated Smads with a common Smad4. (K) Smad complexes are in equilibrium between the cytoplasm and nucleus. Receptor signaling results in a shift in equilibrium toward the nucleus. $(L)$ Binding of the Smad complex and transcription coactivators to activin-responsive elements (AREs) results in the transcription of hundreds of genes, a process that is tightly regulated by a variety of proteins that impact nucleocytoplasmic shuttling, Smad phosphorylation status, Smad degradation, and transcriptional activity. ( $M$ ) Inhibitory Smad7 competes with Smad2 and Smad3 for activated type I receptor binding, thereby preventing Smad2 and Smad3 phosphorylation and facilitating proteasomal degradation or dephosphorylation of activin-receptor complexes.

and ALK-7, respectively) (Tsuchida et al. 2004; Bernard et al. 2006). The ability of activin $\mathrm{B}$ homodimers and activin $\mathrm{AB}$ heterodimers to signal through ALK-7 has been shown in MIN6 pancreatic $\beta$ cells, whereas activin A uses ALK-4, binding ALK-7 with low affinity (Harrison et al. 2003). ALK-4 is also the type I receptor for growth differentiation factors (GDFs) 1, 3, 811 and nodal, and ALK-7 for GDF-1, GDF-3 and nodal (Reissmann et al. 2001; Andersson 
M. Namwanje and C.W. Brown

A

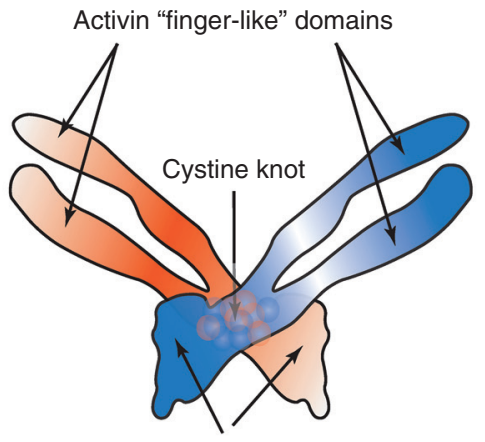

Activin "wrist" domains

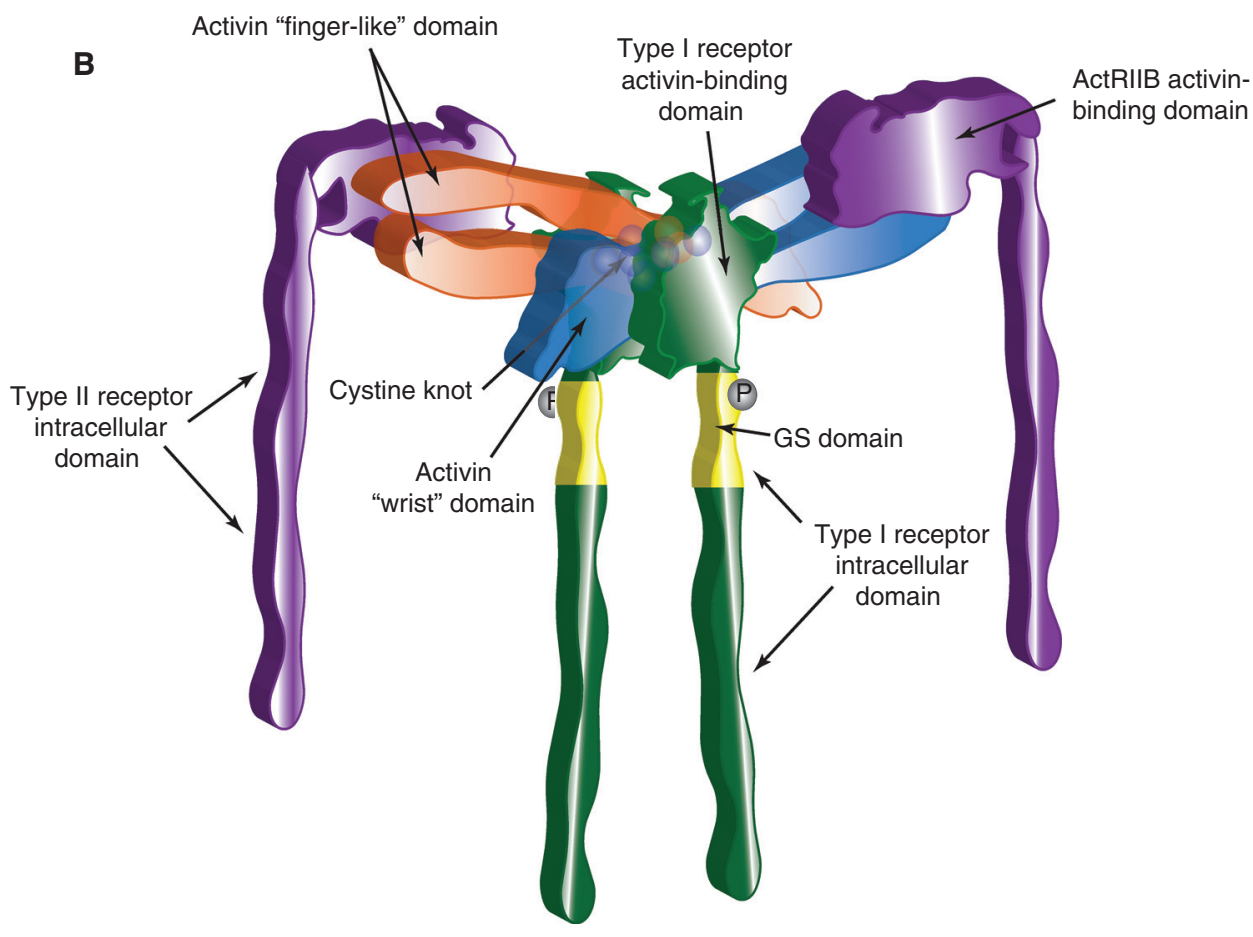

Figure 3. Structures of the activin dimer and activin-receptor complex. (A) Two-dimensional representation of an activin dimer. Two activin monomers associate through interactions between the convex surface of the $\alpha$ helical "wrist" domain of one monomer and the concave surface of the "finger-like" domain, comprised of antiparallel $\beta$-sheets, of the second monomer, giving the appearance of an "open hand" or "butterfly." Covalent dimerization occurs through one of the seven conserved cysteines that define TGF- $\beta$ family ligands. The cysteines are organized into a "cystine knot" (spheres) within the core of the activin dimer. $(B)$ Three-dimensional rendition of the activin-receptor complex. The activin dimer and cystine knot are represented as shades of orange and blue. The assembly of the activin dimer with two activin type II receptors occurs through interactions among the convex surfaces of the ligand finger regions with concave surfaces of each of the type II receptors (shown in purple). The binding of the type II receptors by activin stabilizes the receptors within the cell membrane, yet the flexibility of the bound ligand, shown here as a "spreading" of the activin monomers, allows it to further interact with two type I receptors (shown in green). The type I receptors are subsequently phosphorylated (dark gray spheres) at their glycine-serine rich (GS) domains, shown in yellow, thereby activating the type I receptor kinase. 


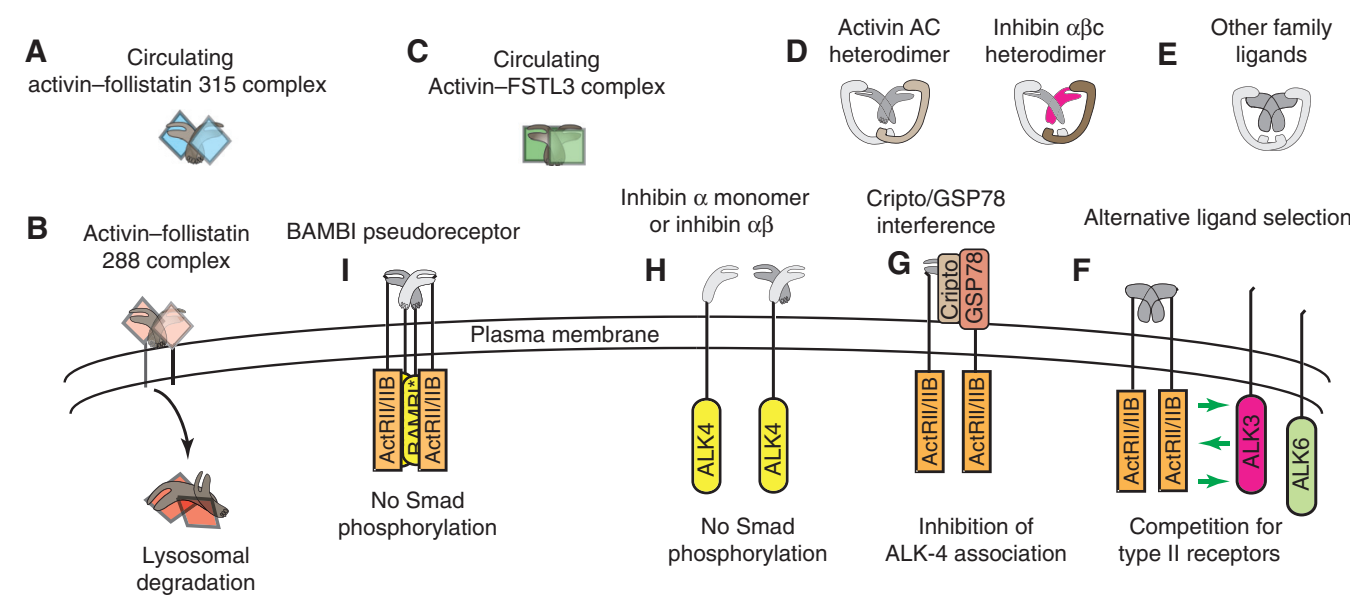

Figure 4. Regulation of activin signaling. $(A, B)$ Follistatin occurs in circulating (follistatin 315$)$ and membranebound (follistatin 288) forms. Activins bind irreversibly to follistatin and the activin-follistatin complex is internalized and degraded in lysosomes $(B)$. (C) FSTL3 is a structurally similar, follistatin-like protein that also binds circulating activins with high affinity and functions as an activin inhibitor. $(D)$ Activin $\beta C$ can heterodimerize with activins $\beta A$ and $\beta B$ as well as inhibin $\alpha$. Some data suggest that "atypical" activins $C$ and E might antagonize activin A or B signaling by forming nonfunctional heterodimers. $(E, F)$ Other TGF- $\beta$ family ligands can bind type II activin receptors, so the potential exists for competition in tissues where ligands and receptors coexpress. $(G)$ Although the EGF-CFC coligand/coreceptor Cripto enhances signaling for some TGF- $\beta$ family ligands, it inhibits functional activin-receptor complexes by binding type II receptor-associated activins, thus preventing the recruitment and phosphorylation of type I receptors. Glucose-regulated protein 78 (GRP78) is also an essential component of this inhibitory complex. $(H)$ In addition to associations with betaglycan, inhibin $\alpha$ monomers and $\alpha \beta$ dimers also bind directly to ALK-4 and inhibit activin signaling in vitro. $(I)$ $\mathrm{BMP}$ and activin membrane-bound inhibitor (BAMBI) is a type I pseudoreceptor that cannot phosphorylate Smads. However, it competes with functional type I receptors for inclusion in activin-receptor complexes, thereby inhibiting activin signaling.

et al. 2008; Wakefield and Hill 2013). The Acvr1b gene encoding ALK-4 produces three alternatively spliced and polyadenylated transcripts, whereas ALK-7, encoded by Acvr1c, is produced from four alternatively spliced transcripts. Two of the proteins lack a transmembrane domain, producing soluble receptors whose functional significance is unknown (ten Dijke et al. 1993; Roberts et al. 2003).

The type II activin receptors are ActRII (also known as ActRIIA) and ActRIIB, encoded by $A c v r 2$ and Acvr2b, respectively. Acvr2b produces four alternatively spliced transcripts that affect activin affinity (Attisano et al. 1992). Other TGF- $\beta$ family ligands, bone morphogenetic proteins (BMPs) $-2,-4,-6$, and -7 can also bind type II activin receptors. However, the repertoire of type I BMP receptors is different, so the potential exists for a competition for type
II activin receptors (Greenwald et al. 2003; Samad et al. 2005; Allendorph et al. 2006, 2007; Koncarevic et al. 2012; Zhang et al. 2013). Binding to the type II receptor results in recruitment and phosphorylation of the type I receptors at several sites within their GS domain, causing activation of type I receptor kinase activity and subsequent phosphorylation of downstream Smad and non-Smad signal transduction proteins. The Smads are the most thoroughly characterized.

\section{Smad-Mediated Signaling}

Smads are intracellular mediators of TGF- $\beta$ family signaling. The first family member, Mothers against decapentaplegic (Mad), was discovered using genetic screens in Drosophila melanogaster (Sekelsky et al. 1995). Mutations 
in three Caenorhabditis elegans orthologs, sma-2, sma-3, and sma-4, all produce developmentally arrested larvae with small body sizes (Savage et al. 1996). Smads were later identified based on their sequence homologies. Vertebrate orthologs of sma and Mad are called Smads (Derynck et al. 1996).

Members of the Smad family play complementary roles in TGF- $\beta$ family signaling. The receptor-regulated (R-) Smads 1, 2, 3, 5, and 8 are phosphorylated by type I receptors after ligand-induced assembly and activation of type I and type II receptor complexes (Fig. 2J) (Heldin et al. 1997; Massagué 1998; Massagué and Chen 2000). Phosphorylation of R-Smads triggers the association with Smad4, which is common to all R-Smad complexes, followed by a shift in homeostasis toward the nucleus to activate or inhibit the transcription of downstream target genes (Fig. 2J-L) (Hill 2009).

Functionally, TGF- $\beta$ family ligands are divided into two main branches based on the receptors with which they interact and the $\mathrm{R}$-Smads that mediate their signals. In general, TGF- $\beta$, activin, and nodal signaling occur through activation of Smads 2 and 3, whereas the BMPs activate Smads 1, 5, and 8. A noteworthy exception to activin-induced Smad2 and 3 phosphorylation has been reported in the context of liver inflammation: the ability of activin B to induce a BMP-like cascade, including a (combined) pSmad1, 5, 8 western blot signal in human hepatoma cells and primary mouse hepatocytes, and consequential expression of the iron regulatory protein, hepcidin (Besson-Fournier et al. 2012).

Accumulation of the Smad complexes within the nucleus is regulated by nuclear transporters and nuclear phosphatases, followed by dissociation of the heteromeric complexes, allowing the Smads to be recycled to the cytoplasm (Lin et al. 2006; Varelas et al. 2008). Inhibitory Smads (I-Smads, i.e., Smad6 and Smad7) block the association of R-Smads with Smad4 and target ligand/receptor complexes for degradation, thereby antagonizing downstream signaling (Ishisaki et al. 1998, 1999). Smad7 is the predominant inhibitory Smad for activin signaling.

\section{Non-Smad Signaling}

In addition to the Smad-mediated signaling pathway, many TGF- $\beta$ family members, including activins, activate other signaling pathways in a variety of cell types, independent of Smad phosphorylation (Cocolakis et al. 2001; Ogihara et al. 2003; Zhang et al. 2005; de Guise et al. 2006; Huang et al. 2006). Other signaling pathways can also alter the stability of Smads by phosphorylating within the Smad linker, resulting in a variety of outcomes that enhance or reduce activity of the Smad complex (reviewed in Massagué 1998). Activin dramatically inhibits the growth of human breast cancer T47D cells, and this requires an intact p38 mitogenactivated protein kinase ( $338 \mathrm{MAPK}$ ) pathway, shown by complete reversal of growth inhibition with selective p38 MAPK inhibitors (Cocolakis et al. 2001).

Neurogenin 3 is an essential transcription factor for pancreatic islet cell differentiation. Relaxation of neurogenin 3 transcriptional repression and the consequential differentiation of AR42J-B13 pancreatic progenitor cells is strongly enhanced by activin A and hepatocyte growth factor (HGF) in combination, whereas HGF alone has a modest effect and activin A alone has no effect. The positive effect on differentiation is attenuated by a dominant negative MAPKK3, or by treatment with a p38 MAPK inhibitor. In contrast, overexpression of inhibitory Smad7 has no effect on activin-/ HGF-induced differentiation implicating activin-/HGF-induced non-Smad signaling as a contributor to pancreatic islet cell differentiation (Ogihara et al. 2003).

Non-Smad-mediated activin signaling has also been shown in keratinocytes, in which activin-induced MEKK1 activation leads to c-Jun amino-terminal kinase (JNK), c-Jun and p38 MAPK phosphorylation, culminating in stress fiber formation and cell migration. The activininduced effects are observed in keratinocytes of wild-type mice, but not in those of MEKK1deficient mice (Zhang et al. 2005). In pituitary prolactin-producing cells an intact p38 MAPK pathway is required for activin inhibition of transcription from the Pit-1 promoter 
(de Guise et al. 2006). Finally, erythropoietic gene expression and cytokine-mediated colony formation of K562 erythroleukemia cells are both affected by activin-induced p38 MAPK activation (Huang et al. 2006). Therefore, nonSmad-mediated activin signaling contributes to processes that impact cell migration and differentiation.

\section{Inhibins and Betaglycan}

Inhibins antagonize activin functions, and their activities as gonad-derived inhibitors of FSH secretion were well recognized for decades before the peptides and cDNAs were identified (McCullagh 1932; Ling et al. 1985; Vale et al. 1994; Aono et al. 1997). We call attention to a recent, extensive review of the inhibins, which includes their historical, biological, and clinical importance (Makanji et al. 2014).

Bioactive inhibins have been isolated from ovarian follicular fluid and plasma of several species (De Jong and Sharpe 1976; Ling et al. 1985; Miyamoto et al. 1985; Rivier et al. 1985; Robertson et al. 1985). Heterodimers of both full-length and fully processed forms of the $\alpha$ and $\beta$ subunits are active in pituitary bioassays (Mason et al. 1996). Exogenously administered inhibin is rapidly cleared from circulation with a half-life ranging from 3 to 6 minutes, which is somewhat shorter than activin. Inhibin targets are more widespread than activins, and activins and inhibins are cosynthesized in a variety of contexts (Woodruff et al. 1993a,c; Makanji et al. 2009).

Betaglycan was originally characterized as a membrane-associated proteoglycan and a type III TGF- $\beta$ receptor that binds TGF- $\beta$ with high affinity and enhances TGF- $\beta$ signaling. Betaglycan can also be released as a soluble proteoglycan after cleavage at the membrane attachment site (Lopez-Casillas et al. 1991). Within the context of activin and inhibin biology, however, its most important function is to regulate activin signaling through direct association with inhibin.

Betaglycan is a coreceptor that enhances inhibin's antagonism of activin signaling (Figs. 1C, 2F). The inhibin $\beta$ subunit binds to one type II activin receptor, competing directly with activin binding. However, the inhibin $\alpha$ subunit cannot bind a second type II receptor. Instead, inhibin $\alpha$ binds betaglycan with high affinity and enhances inhibin's ability to compete with activins for activin type II receptors (Wiater et al. 2009). Betaglycan can also enhance inhibin sensitivity in cells that normally respond poorly to inhibin (Lewis et al. 2000). Silencing betaglycan expression or neutralizing betaglycan antibody in cultured primary anterior pituitary cells blocks the interaction of inhibin $\mathrm{A}$ and betaglycan, and reverses inhibin effects without affecting the cellular responses to activin. Repressing betaglycan expression also reduces inhibin antagonism of activin-induced FSH secretion, with a $>1000$-fold reduction in the response to inhibin A in cells treated with neutralizing antibody (Wiater et al. 2009). In addition to its associations with betaglycan, inhibin $\alpha$ monomers and $\alpha \beta$ dimers can associate directly with ALK-4, and an amino-terminal inhibin $\alpha$ peptide is sufficient to inhibit activin signaling and activin-induced FSH production in cultured pituitary gonadotropes (Zhu et al. 2012).

\section{Cripto and GRP78}

Cripto is a glycosylphosphatidylinositol-anchored, cell surface coreceptor in the epidermal growth factor-Cripto-1/FRL-1/Cryptic family that participates in embryonic development and cell growth regulation through effects on many TGF- $\beta$ family ligands, either enhancing (Vg1, nodal, GDF-1, GDF-3) or diminishing (activin A, activin B, TGF- $\beta 1$ ) their bioactivities (Cheng et al. 2003; Gray et al. 2003, 2006; Chen et al. 2006; Kelber et al. 2007; Shen 2007). Cripto effects occur through a complex on the cell surface that includes glucose-regulated protein 78 (GRP78) (Shani et al. 2008; Kelber et al. 2009) (Fig. 4G). Cripto forms a complex with activin A or B and either ActRII or ActRIIB, but is incapable of binding activins directly. On association with activin and type II receptors, Cripto blocks the interaction with ALK-4 and inhibits activin signaling in HepG2 and 293T cells (Gray et al. 2003). Disrupting the Cripto-GRP78 interaction by silencing GRP78 
expression or using GRP78 neutralizing antibody blocks the modulatory effects of Cripto on activin A and B signaling, confirming an essential role for GRP78 in Cripto-mediated antagonism of activin-receptor complexes (Kelber et al. 2009).

\section{$B M P$ and Activin Membrane-Bound Inhibitor (BAMBI)}

BAMBI is structurally related to type I receptors but lacks the kinase domain. Orthologs have been identified in several species (Degen et al. 1996; Tsang et al. 2000; Grotewold et al. 2001; Loveland et al. 2003). BAMBI is coexpressed with BMP-4 during Xenopus embryogenesis and its expression requires BMP signaling. The protein stably associates with several TGF- $\beta$ family receptors, including ALK-4, and inhibits activin, BMP, and TGF- $\beta$ signaling. BAMBI inhibits ligand signaling through its intracellular domain, which contains a type I receptor homodimerization interface, thereby preventing the assembly of activated receptor complexes (Fig. 4I). To our knowledge, no effects on ligand binding have been reported. Thus, BAMBI is a pseudoreceptor that can inhibit activin signaling (Onichtchouk et al. 1999).

\section{Follistatin and Follistatin-Like 3}

Activins are antagonized by follistatin, an activin-binding protein that affects the accessibility of activins to their receptors thereby attenuating activin-mediated FSH release, a function from which its name is derived (Esch et al. 1987; Ueno et al. 1987; Nakamura et al. 1990; Sidis et al. 2006). There are three alternatively spliced products of the single follistatin gene, designated Fst288, Fst303, and Fst315. The carboxyl termini of these isoforms differ. Fst315 is the predominant form in circulation, whereas Fst288 is membrane-bound through its interaction with cell surface heparan sulfate proteoglycans (Fig 4A,B). Fst303 is also membranebound but has a lower affinity than Fst288. The membrane association provides the mechanism by which bound activins are internalized and degraded (Fig. 4B), and in part explains the different bioactivities for the follistatin isoforms (Sugino et al. 1993; Hashimoto et al. 1997). Follistatin was originally isolated from ovarian follicular fluid, the site of production for all isoforms except Fst315, suggesting an alternative source of production for the circulating form, and possibly specialized functions for each isoform (Schneyer et al. 2004). Follistatins have up to three follistatin domains, bind both activin A and activin B, but have a 10-fold higher affinity for activin A (Schneyer et al. 2003). Follistatin also binds GDF-8 (myostatin), GDF-11, BMP-2, BMP-4, BMP-6, and BMP-7 with progressively lower affinities (Glister et al. 2004; Sidis et al. 2006; Schneyer et al. 2008). Structural and mutagenesis data have shown that two follistatin molecules block the sites of interaction between dimeric activin and type I and type II activin receptors (Thompson et al. 2005; Harrington et al. 2006; Harrison et al. 2006). Follistatin-like 3 (FSTL-3) interacts with activin in a similar fashion, but the points of contact differ (Stamler et al. 2008).

FSTL-3, also known as follistatin-related gene (FLRG) (Hayette et al. 1998; Tsuchida et al. 2000) and FST-related protein (FSRP) (Schneyer et al. 2001) (herein, FSTL-3), lacks the third follistatin domain and the heparanbinding motif, thereby restricting it to the circulation (Fig. 4C) (Sidis et al. 2005). Follistatin and FSTL-3 are differentially expressed. Follistatin is generally coexpressed with activins and most highly expressed in the ovary and pituitary (Besecke et al. 1997; Arai et al. 2002; Bilezikjian et al. 2004), but also detected in several other tissues (Ogawa et al. 1993; Inoue et al. 1994; Petraglia et al. 1994; Michel et al. 2000; Sonoyama et al. 2000; Bloise et al. 2009; Lima et al. 2010). FSTL-3 has a different, but overlapping distribution, and is also expressed at high levels in several tissues (Wankell et al. 2001a; Ciarmela et al. 2003; Florio et al. 2004; Xia et al. 2004; Takehara-Kasamatsu et al. 2007; Allen et al. 2008; Bloise et al. 2009). Like follistatin, FSTL-3 has the capacity to bind and regulate other TGF- $\beta$ family ligands, including myostatin and several BMPs (Tsuchida et al. 2000; Lee and McPherron 2001; Otsuka et al. 2001; Hill et al. 2002; Maguer-Satta et al. 2003). 


\section{ROLES OF ACTIVINS AND INHIBINS IN DEVELOPMENT}

The expression of activins, inhibins, their receptors and regulatory proteins is dynamic and widespread. Therefore, it is not surprising that activin signaling participates in a variety of biological processes that impact embryonic development, growth, as well as functions of fully differentiated cell types (Table 1).

\section{Spatiotemporal Expression}

Although recombinant activin A and activin B have similar biological activities in vitro (Mason et al. 1989; Mathews and Vale 1991), the spatiotemporal expression of activins, their receptors, and regulatory proteins differs greatly during embryonic and fetal development. The mRNAs encoding activin $\beta \mathrm{A}$ and activin $\beta \mathrm{B}$ are present at early stages of embryonic development and in embryonic stem cells (Albano and Smith 1994). Activin signaling contributes to the maintenance of the pluripotent state of human embryonic stem cells (Wu et al. 2008; Xu et al. 2008) and to developmental cell fate decisions (Hay et al. 2008; Pearson et al. 2008; Sumi et al. 2008). Several developing organs and tissues express activins or activin receptors, including the roof of the oral cavity, mesenchyme underlying the tooth primordia and other regions of head mesenchyme, esophagus, developing whiskers, vasculature, vertebral bodies, heart, external genitalia, and the developing limb (Feijen et al. 1994; Roberts and Barth 1994; Merino et al. 1999). In contrast, activin $\beta B$ mRNA localizes primarily to the gonad, forebrain, hindbrain, spinal cord, stomach, and esophagus in mouse and rat embryos. Type II activin receptors generally colocalize with sites of activin production, and inhibin $\alpha$ localizes to the developing gonad (Feijen et al. 1994; Roberts and Barth 1994). In adult female rats, radiolabled activin A protein binds to the pituitary and ovary, whereas inhibin A localizes to the spleen, adrenal, pituitary, specific stages of ovarian follicles in adult rats and in the bone marrow (Woodruff et al. 1993a,b).

The developing gonad and esophagus are the only tissues, in which activin $\beta \mathrm{A}$ and $\beta \mathrm{B}$ are coexpressed in the mouse embryo, although an overlapping pattern of expression has been observed in the developing chick limb (Merino et al. 1999). In general, activin $\beta A$ mRNA is more widespread than activin $\beta B$ in both mouse and rat embryos, and the timing of expression differs.

\section{Mouse Models}

Several genetically engineered mouse models have been produced to assess the biological functions of the activins and inhibins. These experiments are summarized in Table 2.

\section{Activins $A$ and $B$}

Genetic studies in mice have shown that activin $\beta$ A homozygous null mutant mice (Inhba ${ }^{-/-}$) are born without whiskers, incisors, and mandibular molars. Approximately 30\% also have cleft palate. The pups do not suckle and die within 24 h (Matzuk et al. 1995c). In contrast, Inhb $b^{-/-}$mice are viable and fertile but have eyelid closure defects, prolongation of the gestational period, and are unable to nurse their young (Schrewe et al. 1994; Vassalli et al. 1994). Inhba ${ }^{-/-}$; Inhbb ${ }^{-/-}$double mutant mice have phenotypes that are additive of each of the individual null mutants, with no additional abnormalities (Matzuk et al. 1995c).

Mice, in which the mature domain of activin $\beta A$ is replaced with that of activin $\beta B$ $\left(\operatorname{Inh} b a^{\mathrm{BK}}\right)$, display a dosage-sensitive complete or partial rescue of all the phenotypes of Inhba $a^{-/-}$mice (Brown et al. 2000), suggesting that activin $\beta B$ is functionally hypomorphic relative to the wild-type activin $\beta$ A protein in some developmental contexts.

\section{Follistatin}

A homozygous null mutation of the Fst gene causes early neonatal lethality as a result of respiratory failure. The mice have taut, shiny skin, hypoplastic respiratory musculature, and craniofacial abnormalities affecting the palate, whiskers, and teeth bearing some similarities to Inhba ${ }^{-/-}$mice (Matzuk et al. 1995d).

Transgenic mice that selectively express either the Fst 288 or Fst315 isoform driven by 
M. Namwanje and C.W. Brown

Table 1. Biological functions of activins and inhibins

\begin{tabular}{|c|c|c|c|}
\hline Proteins & Tissue/cell types & Biological functions & References \\
\hline \multicolumn{4}{|c|}{ Development } \\
\hline Activin & $\begin{array}{l}\text { Human embryonic stem } \\
\text { cells }\end{array}$ & Maintenance of pluripotency & $\begin{array}{l}\text { Wu et al. 2008; Xu et al. } \\
2008\end{array}$ \\
\hline Activin A & Craniofacial (mouse) & Whisker, palate, and tooth development & $\begin{array}{l}\text { Matzuk et al. 1995d; } \\
\text { Brown et al. } 2000\end{array}$ \\
\hline Activin A & Mouse tissues & $\begin{array}{l}\text { Supports total body weight gain and } \\
\text { the growth of gonads, fat, and liver }\end{array}$ & $\begin{array}{l}\text { Brown et al. 2000; Li } \\
\text { et al. } 2009\end{array}$ \\
\hline Activin B & Mammary gland & $\begin{array}{l}\text { Stroma-supported ductal elongation, } \\
\text { alveolar morphogenesis, and luminal } \\
\text { expansion }\end{array}$ & $\begin{array}{l}\text { Vassalli et al. 1994; } \\
\text { Robinson and } \\
\text { Hennighausen } 1997\end{array}$ \\
\hline Activin B & Craniofacial (mouse) & Prenatal eyelid fusion & $\begin{array}{l}\text { Schrewe et al. 1994; } \\
\text { Vassalli et al. } 1994\end{array}$ \\
\hline Activin D & All stages, Xenopus embryos & Mesoderm induction & Oda et al. 1995 \\
\hline
\end{tabular}

\section{Nervous system}

Activin A E18 rat retinal progenitors Induces differentiation into rod Davis et al. 2000
photoreceptors

Activin A Cultured P19 teratoma cells, Increased survival beyond life spa rat B50 nerve cells and under normal culture conditions

Schubert et al. 1990 chick neural retinal cells

Activin A Rat mesencephalon dopaminergic cells

Activin A Hippocampus and

Protects against $N$-methyl-4phenylpiridinium ion toxicity

Protection against neuronal death dorsolateral striatum

Activin A Striatal cholinergic interneurons

Activin B + Oligodendrocytes TGF- $\beta 1$
Activin Drosophila embryos orthologs induced by hypoxic-ischemic brain injury

Protects against chemically induced neurodegeneration

Together enhance proliferation, viability, Dutta et al. 2014 maturation, and myelination during embryonic development

Promote neuron growth and photoreceptor axon targeting

Krieglstein et al. 1995

Wu et al. 1999

Hughes et al. 1999

Reproduction

Activin Pituitary gonadotropes

Augments GnRH-induced FSH release

Ling et al. 1986a; Vale et al. 1986

Activin A Cultured ovarian granulosa

Increases DNA synthesis, augmented by Kipp et al. 2007 cells $\mathrm{FSH}$; increases expression of estrogen receptor; enhances proliferation of cells from human pre-ovulatory follicles

Activin A Cultured ovarian theca cells

Blocks LH-induced androgen production

Activin A Cultured ovarian luteal cells

Blocks LH-induced progesterone

Hillier et al. 1991b production

Activin B Developing gonad

Coelomic vessel formation in developing male gonads

Zhu et al. 2008

Activin A Fetal Sertoli cells

Activin A from fetal Leydig cells supports Archambeault and Sertoli cell proliferation and testis Yao 2010 cord elongation 
Table 1. Continued

\begin{tabular}{|c|c|c|c|}
\hline Proteins & Tissue/cell types & Biological functions & References \\
\hline Activin A & Cultured Sertoli cells & $\begin{array}{l}\text { Enhances proliferation alone or in } \\
\text { combination with FSH; induces } \\
\text { production of inhibin and follistatin; } \\
\text { causes reversion to an immature, } \\
\text { proliferative state }\end{array}$ & $\begin{array}{l}\text { Buzzard et al. 2003; } \\
\text { Nicholls et al. } 2012\end{array}$ \\
\hline Activin A & Cultured Leydig cells & $\begin{array}{l}\text { Blocks LH-induced androgen } \\
\text { production }\end{array}$ & Mauduit et al. 1991 \\
\hline Activin A & Germ/Sertoli cell coculture & Increases germ cell/Sertoli cell ratio & Meehan et al. 2000 \\
\hline Inhibin & Ovarian granulosa cells & $\begin{array}{l}\text { Antagonizes proliferation of granulosa } \\
\text { cells at the single-layer follicle stage; } \\
\text { ovarian tumor suppression }\end{array}$ & $\begin{array}{l}\text { Matzuk et al. 1992; Wu } \\
\text { et al. } 2004\end{array}$ \\
\hline Inhibin & Ovarian theca cells & Promotes steroidogenesis & Wu et al. 2004 \\
\hline Inhibin B & Testis & $\begin{array}{l}\text { Possible paracrine role in } \\
\text { spermatogenesis by supporting germ, } \\
\text { Sertoli, and Leydig cell interactions }\end{array}$ & $\begin{array}{l}\text { Clifton et al. 2002; } \\
\text { Kumanov et al. } 2006\end{array}$ \\
\hline Inhibin & Pituitary gonadotropes & $\begin{array}{l}\text { Negative regulator of FSH production } \\
\text { and release }\end{array}$ & $\begin{array}{l}\text { Setchell and Jacks 1974; } \\
\text { De Jong and Sharpe } \\
1976\end{array}$ \\
\hline Inhibin & Ovarian granulosa cells & $\begin{array}{l}\text { Antagonizes proliferation of granulosa } \\
\text { cells at the single-layer follicle stage }\end{array}$ & Wu et al. 2004 \\
\hline Inhibin & Ovarian theca cells & Promotes steroidogenesis & Wu et al. 2004 \\
\hline Inhibin & Placenta & $\begin{array}{l}\text { Blocks activin-mediated steroidogenesis } \\
\text { and HCG production }\end{array}$ & $\begin{array}{l}\text { Petraglia et al. 1989; } \\
\text { Jones et al. } 2006\end{array}$ \\
\hline \multicolumn{4}{|c|}{ Body composition and energy metabolism } \\
\hline Activin A & Liver & Induces hepatocyte apoptosis & Schwall et al. 1993 \\
\hline Activin A & $\begin{array}{l}\text { Human preadipocytes, } \\
\text { mouse } 3 \mathrm{~T} 3-\mathrm{L} 1 \\
\text { preadipocytes }\end{array}$ & $\begin{array}{l}\text { Increases proliferation while inhibiting } \\
\text { differentiation }\end{array}$ & Zaragosi et al. 2010 \\
\hline Activin B & 3T3-L1 mature adipocytes & $\begin{array}{l}\text { Reduces lipolysis and lipase gene } \\
\text { expression }\end{array}$ & Magnusson et al. 2010 \\
\hline $\begin{array}{l}\text { Activin A + } \\
\text { HGF }\end{array}$ & $\begin{array}{l}\text { AR42J-B13 pancreatic } \\
\text { progenitor cells }\end{array}$ & $\begin{array}{l}\text { Relaxation of neurogenin-3 } \\
\text { transcriptional repression, enhancing } \\
\text { differentiation }\end{array}$ & Ogihara et al. 2003 \\
\hline $\begin{array}{l}\text { ActRIIB } \\
\text { signaling }\end{array}$ & Adipose and muscle & $\begin{array}{l}\text { Influences lean/fat body mass ratio, } \\
\text { "britening" of white adipose, } \\
\text { peripheral glucose uptake and hepatic } \\
\text { glucose production }\end{array}$ & $\begin{array}{l}\text { Akpan et al. 2009; } \\
\text { Fournier et al. 2012; } \\
\text { Koncarevic et al. } \\
\text { 2012; Zhang et al. } \\
2012\end{array}$ \\
\hline $\begin{array}{l}\text { Activins A } \\
\text { and B }\end{array}$ & Pancreatic islets & $\begin{array}{l}\text { Affect islet cell differentiation, growth, } \\
\text { calcium signaling, } \alpha-/ \beta \text {-cell ratio, } \\
\text { and insulin release }\end{array}$ & $\begin{array}{l}\text { Yamaoka et al. 1998; } \\
\text { Bertolino et al. 2008; } \\
\text { Bonomi et al. } 2012\end{array}$ \\
\hline $\begin{array}{l}\text { Activin } \\
\text { ortholog } \\
\text { (dawdle) }\end{array}$ & Drosophila embryos & $\begin{array}{l}\text { Regulates triglyceride, glycogen, and } \\
\text { glucose metabolism and } \\
\text { corresponding Krebs cycle, oxphos, } \\
\text { and fatty acid oxidation enzymes }\end{array}$ & $\begin{array}{l}\text { Ghosh and O'Connor } \\
2014\end{array}$ \\
\hline Activin C & Liver & $\begin{array}{l}\text { Possible effects on hepatocellular } \\
\text { proliferation }\end{array}$ & $\begin{array}{l}\text { Chabicovsky et al. 2003; } \\
\text { Takamura et al. 2005; } \\
\text { Wada et al. } 2005\end{array}$ \\
\hline
\end{tabular}

Continued 
M. Namwanje and C.W. Brown

Table 1. Continued

\begin{tabular}{|c|c|c|c|}
\hline Proteins & Tissue/cell types & Biological functions & References \\
\hline \multicolumn{4}{|l|}{ Inflammation } \\
\hline Activin A & $\begin{array}{l}\text { Mouse macrophage } \\
\text { RAW264.7 }\end{array}$ & $\begin{array}{l}\text { Increases IL-1 } \beta \text {, IL- } 6, \mathrm{CD} 80 \text {, } \\
\text { macrophage activation, and } \\
\text { phagocytosis }\end{array}$ & Ge et al. 2009 \\
\hline Activin A & $\begin{array}{l}\text { Human peripheral blood } \\
\text { monocytes }\end{array}$ & $\begin{array}{l}\text { Supports the proinflammatory } \mathrm{M} 2 \\
\text { macrophage phenotype }\end{array}$ & $\begin{array}{l}\text { Sierra-Filardi et al. } \\
2011\end{array}$ \\
\hline Activin B & $\begin{array}{l}\text { Human hepatoma and } \\
\text { mouse primary } \\
\text { hepatocytes }\end{array}$ & $\begin{array}{l}\text { Increases expression of hepcidin } \\
\text { during inflammation, mediated } \\
\text { by Smad } 1 / 5 / 8 \text { phosphorylation }\end{array}$ & $\begin{array}{l}\text { Besson-Fournier et al. } \\
\quad 2012\end{array}$ \\
\hline \multicolumn{4}{|c|}{ Erythropoiesis } \\
\hline Activin A & K562 erythroleukemia cells & $\begin{array}{l}\text { Augments EPO-dependent hemoglobin } \\
\text { production }\end{array}$ & Yu et al. 1987 \\
\hline Inhibin & $\begin{array}{l}\text { K562 human leukemia and } \\
\text { primary human bone } \\
\text { marrow cells }\end{array}$ & $\begin{array}{l}\text { Suppresses activin-induced } \\
\text { differentiation and EPO-induced } \\
\text { CFU formation }\end{array}$ & Yu et al. 1987 \\
\hline Activin & $\begin{array}{l}\text { Human bone marrow- } \\
\text { derived erythrocyte } \\
\text { precursors }\end{array}$ & Enhanced proliferation & Yu et al. 1987 \\
\hline \multicolumn{4}{|c|}{ Miscellaneous } \\
\hline $\begin{array}{l}\text { Activins } \mathrm{A} \text {, } \\
\mathrm{B} \text {, and } \mathrm{AB}\end{array}$ & Myoblasts & Inhibits myotube differentiation & Souza et al. 2008 \\
\hline Activin A & Muscle & Negatively regulates muscle mass & Chen et al. 2015 \\
\hline Activin & $\begin{array}{l}\text { Human breast cancer T47D } \\
\text { cells }\end{array}$ & p38 MAPK-mediated growth inhibition & Cocolakis et al. 2001 \\
\hline $\begin{array}{l}\text { Activins A } \\
\text { and B }\end{array}$ & $\begin{array}{l}\text { Human neuroblastoma and } \\
\text { rat pheochromocytoma }\end{array}$ & $\begin{array}{l}\text { Protect against serum withdrawal- } \\
\text { induced apoptosis }\end{array}$ & Kupershmidt et al. 2007 \\
\hline Inhibin & Bone & Positive effects on bone mineral density & $\begin{array}{l}\text { Vural et al. 2005; } \\
\text { Perrien et al. 2006; } \\
\text { Perrien et al. } 2007\end{array}$ \\
\hline Activin & Keratinocytes & $\begin{array}{l}\text { Stress fiber formation and enhanced } \\
\text { cell migration through non-Smad- } \\
\text { mediated signaling }\end{array}$ & Zhang et al. 2005 \\
\hline Inhibin & Adrenal cortex & Tumor suppression & $\begin{array}{l}\text { Matzuk et al. 1992; } \\
\text { Looyenga and } \\
\text { Hammer } 2006\end{array}$ \\
\hline
\end{tabular}

endogenous regulatory sequences were generated to determine whether either could rescue the defects of follistatin null mice (Lin et al. 2008). Mice expressing the Fst315 circulating isoform on a $\mathrm{Fst}^{-/}$- background survive to adulthood, but are small with poor vascular perfusion of the distal tail, and have reproductive abnormalities. However, the survival of mice with the Fst288 membrane-bound isoform is only marginally improved relative to $\mathrm{Fst}^{-/}$mice. In contrast, an Fst targeted insertion allele that results in the production of Fst288 only, is sufficient for sur- vival. The reason for the difference among these models is unclear, perhaps reflecting the welldescribed, dosage-sensitive effects of activinreceptor signaling. Nevertheless, both observations support unique roles for follistatin isoforms in development and reproduction.

\section{Activin $C$ and Activin E}

Data concerning the functional roles of activin $\mathrm{C}$ in the liver are conflicting. Transient reduction of activin $\mathrm{C}$ expression occurs after partial 
Activins and Inhibins

Table 2. Mouse models of activin- and inhibin-related loss- and gain-of-function

\begin{tabular}{|c|c|c|}
\hline Genotypes & Phenotypes & References \\
\hline \multicolumn{3}{|c|}{ Loss-of-function/hypomorphic } \\
\hline \multicolumn{3}{|c|}{ Single-activin/inhibin mutants } \\
\hline Inhba & $\begin{array}{l}\text { Failure to develop whiskers, incisors, mandibular molars; } \\
\text { cleft palate }(\sim 30 \%) \text {, neonatal lethality }\end{array}$ & Matzuk et al. 1995d \\
\hline $\operatorname{Inh} b a^{-/-}$ & $\begin{array}{l}\text { Aberrant (absent) whisker development leads to secondary } \\
\text { defects in whisker-associated trigeminal sensory function }\end{array}$ & Jhaveri et al. 1998 \\
\hline $\operatorname{Inh} b a^{-/-}$ & $\begin{array}{l}\text { Specific decrease in the number of retinal rod } \\
\text { photoreceptors }\end{array}$ & Davis et al. 2000 \\
\hline $\operatorname{Inh} b b^{-1-}$ & $\begin{array}{l}\text { Eyelid closure defect, prolonged gestation, impaired } \\
\text { lactation, normal growth, gonadal differentiation, } \\
\text { fertility, and survival; normal whisker and tooth } \\
\text { development; no cleft palate }\end{array}$ & $\begin{array}{l}\text { Schrewe et al. 1994; } \\
\text { Vassalli et al. } 199\end{array}$ \\
\hline $\operatorname{Inh} b a^{\mathrm{BK} / \mathrm{BK}}$ & $\begin{array}{l}\text { Normal whisker and tooth development; no cleft palate; } \\
\text { symmetrical growth deficiency (moderate), enlargement } \\
\text { of external genitalia, hypogonadism (moderate), sunken } \\
\text { eyes, short hair, delayed hair growth (mild), diminished } \\
\text { female fertility, decreased life expectancy (mild/ } \\
\text { moderate), decreased white adipose (moderate), } \\
\text { increased metabolic rate, mitochondrial dysfunction }\end{array}$ & $\begin{array}{l}\text { Brown et al. } 2000 \text {; } \\
\quad \text { Li et al. } 2009\end{array}$ \\
\hline $\operatorname{Inhb} a^{\mathrm{BK} /-}$ & $\begin{array}{l}\text { Short whiskers, normal tooth development; no cleft palate; } \\
\text { symmetrical growth deficiency with reduced adiposity } \\
\text { (severe), enlargement of external genitalia, } \\
\text { hypogonadism (severe), delayed hair growth (moderate); } \\
\text { decreased life expectancy (severe) }\end{array}$ & $\begin{array}{l}\text { Brown et al. } 2000 \text {; } \\
\quad \text { Li et al. } 2009\end{array}$ \\
\hline $\operatorname{Inh} b c^{-1-}$ & $\begin{array}{l}\text { No effects on development, liver cytoarchitecture, function, } \\
\text { or regenerative capacity }\end{array}$ & Lau et al. 2000 \\
\hline Inhbe $e^{-/-}$ & $\begin{array}{l}\text { No effects on development, liver cytoarchitecture, function, } \\
\text { or regenerative capacity }\end{array}$ & Lau et al. 2000 \\
\hline Inha $a^{-1-}$ & $\begin{array}{l}\text { Gonadal sex cord stromal and adrenal tumors, cachexia, } \\
\text { absent parietal cells in the glandular stomach, and } \\
\text { hepatocellular necrosis }\end{array}$ & Matzuk et al. 1992 \\
\hline
\end{tabular}

\section{Activin receptor mutants}

\begin{tabular}{|c|c|}
\hline Acvr2 $2^{-1-}$ & $\begin{array}{l}\text { 25\% die perinatally from cleft palate/Pierre Robin } \\
\text { sequence; males have delayed fertility; females are } \\
\text { infertile }\end{array}$ \\
\hline Acvr $2 b^{-/-}$ & $\begin{array}{l}\text { Perinatal lethal in a subset; left-right asymmetry and } \\
\text { anteroposterior axis defects }\end{array}$ \\
\hline Acvr1b $b^{-/-}(A l k 4)$ & Embryonic lethal; disrupted primitive streak \\
\hline $\begin{array}{l}\text { dnAcvrlb (driven by } \\
\text { CaMKII- } \alpha)\end{array}$ & $\begin{array}{l}\text { Dominant negative ActRIB expression in developing } \\
\text { forebrain makes hippocampal neurons more susceptible } \\
\text { to excitotoxic injury; reduced glutamatergic } \\
\text { neurotransmission and impaired long-term potentiation }\end{array}$ \\
\hline $\mathrm{Bambi}^{-/-}$ & $\begin{array}{l}\text { Regulation of mechanisms involved in acute and chronic } \\
\text { pain sensitivity; no apparent developmental defects }\end{array}$ \\
\hline Acvr $1 c^{-/-}(A l k 7)$ & $\begin{array}{l}\text { Progressive hyperinsulinemia, reduced insulin sensitivity, } \\
\text { fatty liver, impaired glucose tolerance, pancreatic islet } \\
\text { enlargement, reduced fat accumulation, and partial } \\
\text { resistance to diet-induced obesity }\end{array}$ \\
\hline
\end{tabular}

Matzuk et al. 1995b

Oh and Li 1997

Gu et al. 1998

Muller et al. 2006

Chen et al. 2007;

Tramullas et al. 2010

Andersson et al. 2008;

Bertolino et al. 2008

Continued 
M. Namwanje and C.W. Brown

Table 2. Continued

\begin{tabular}{|c|c|c|}
\hline Genotypes & Phenotypes & References \\
\hline $\mathrm{Fst}^{-/-}$ & $\begin{array}{l}\text { Neonatal lethality because of respiratory failure, hypoplasia } \\
\text { of respiratory musculature, abnormal skin, and } \\
\text { craniofacial malformations }\end{array}$ & Matzuk et al. 1995d \\
\hline $\mathrm{Fst}^{-/-}$ & $\begin{array}{l}\text { Aberrant (short, curled) whisker development leads to } \\
\text { secondary defects in whisker-associated trigeminal } \\
\text { sensory function }\end{array}$ & Jhaveri et al. 1998 \\
\hline $\mathrm{Fst}^{-/-}$ & $\begin{array}{l}\text { Ectopic coelomic vessel formation in developing female } \\
\text { gonads }\end{array}$ & Yao et al. 2004 \\
\hline$F_{s t l 3}{ }^{-/-}$ & $\begin{array}{l}\text { Increased pancreatic islet number and size, with } \beta \text {-cell } \\
\text { hyperplasia, diminished white fat, and beneficial effects } \\
\text { on glucose metabolism }\end{array}$ & Mukherjee et al. 2007 \\
\hline$T g f b r 3^{-1-}$ & $\begin{array}{l}\text { Tgfbr3 (betaglycan) knockout causes lethal proliferative } \\
\text { defects in heart and apoptosis in liver, occurring at E13.5 }\end{array}$ & Stenvers et al. 2003 \\
\hline \multicolumn{3}{|c|}{ Double and triple mutants } \\
\hline $\begin{array}{l}\text { Inhba } \\
\quad \operatorname{Inh} b b^{-/-}\end{array}$ & $\begin{array}{l}\text { Combined features of the single mutations with no } \\
\text { additional defects }\end{array}$ & Matzuk et al. 1995d \\
\hline $\begin{array}{l}\operatorname{Inh} b a^{\mathrm{BK} / \mathrm{BK}} \\
\operatorname{Inh} b b^{-/-}\end{array}$ & $\begin{array}{l}\text { Symmetrical growth deficiency (severe), eyelid closure } \\
\text { defect, prominence of external genitalia, hypogonadism } \\
\text { (severe), delayed hair growth (moderate), decreased life } \\
\text { expectancy (severe), decreased adipose (severe) }\end{array}$ & Brown et al. 2003 \\
\hline $\begin{array}{l}\text { Inhbb }{ }^{-/-} \\
\quad F_{s t}{ }^{-/-}\end{array}$ & $\begin{array}{l}\text { Rescue of Inhbb-mediated ectopic coelomic vessel } \\
\text { formation in developing female gonads }\end{array}$ & Yao et al. 2006 \\
\hline $\begin{array}{l}\text { Inhbb } \\
\text { Wnt4 } \\
-1-\end{array}$ & $\begin{array}{l}\text { Rescue of Inhbb-mediated ectopic coelomic vessel } \\
\text { formation in developing female gonads }\end{array}$ & Yao et al. 2006 \\
\hline $\begin{array}{l}\text { Inhbc } c^{-/-} ; \\
\quad \text { Inhbe }\end{array}$ & $\begin{array}{l}\text { No effects on development, liver cytoarchitecture, function, } \\
\text { or regenerative capacity }\end{array}$ & Lau et al. 2000 \\
\hline $\begin{array}{l}\text { Acvr2 } 2^{+/-} ; \\
\quad \operatorname{Acvr} 2 b^{+/-}\end{array}$ & $\begin{array}{l}\text { Abnormal development of stomach, spleen, and endocrine } \\
\text { pancreas }\end{array}$ & Kim et al. 2000 \\
\hline $\begin{array}{l}\text { Acvr2 } 2^{-1-} \\
\quad \operatorname{Acvr} 2 b^{+/-}\end{array}$ & $\begin{array}{l}\text { Embryos fail to form an elongated primitive streak, causing } \\
\text { disruption of the mesoderm formation }\end{array}$ & Song et al. 1999 \\
\hline $\begin{array}{l}\text { Acvr2 } 2^{+/-} \\
\quad \text { Acvr } 2 b^{-/-}\end{array}$ & $\begin{array}{l}\text { Late gestational or early neonatal lethality; modest effect on } \\
\text { rostral development }\end{array}$ & Song et al. 1999 \\
\hline $\begin{array}{l}\text { Acvr2 } 2^{-1-} ; \\
\quad \text { Acvr } 2 b^{-/-}\end{array}$ & $\begin{array}{l}\text { Arrested at the egg cylinder stage and do not form } \\
\text { mesoderm }\end{array}$ & Song et al. 1999 \\
\hline $\begin{array}{l}\text { Inha } \\
\qquad \text { Acvr } 2^{-/-}\end{array}$ & $\begin{array}{l}\text { Gonadal tumor development but rescue of } \\
\text { Inha }{ }^{-/-} \text {cachexia and hepatocellular necrosis }\end{array}$ & Coerver et al. 1996 \\
\hline $\begin{array}{l}\text { Inha }{ }^{-/-} \\
\quad F s h^{-/-}\end{array}$ & $\begin{array}{l}\text { Increased survival and milder tumor/cachexia phenotypes } \\
\text { relative to Inha } a^{-/-} \text {mice }\end{array}$ & Kumar et al. 1999 \\
\hline $\begin{array}{l}\text { Inha } \\
\qquad r^{-/-}\end{array}$ & $\begin{array}{l}\text { Inhibin/androgen receptor double mutants have increased } \\
\text { survival and milder tumor/cachexia phenotypes relative } \\
\text { to Inha }{ }^{-/-} \text {mice }\end{array}$ & Shou et al. 1997 \\
\hline $\begin{array}{l}\text { Inha }{ }^{-/-} \\
\quad \text { Esr } 1^{-1-} \\
\quad \text { Esr } 2^{-/-}\end{array}$ & $\begin{array}{l}\text { Protection from early gonadal tumorigenesis in males only. } \\
\text { Single estrogen receptor }(E s r) \text { knockouts are not } \\
\text { sufficient to confer a protective effect }\end{array}$ & Burns et al. 2003a \\
\hline $\begin{array}{l}\text { Inha } a^{-1-} \\
\qquad \operatorname{Lh} b^{-/-}\end{array}$ & $\begin{array}{l}\text { Increased survival and milder tumor/cachexia phenotypes } \\
\text { relative to Inha } a^{-/-} \text {mice }\end{array}$ & Nagaraja et al. 2008 \\
\hline $\begin{array}{l}\text { Inha }{ }^{-/-} \text {; } \\
\qquad \operatorname{Inhbc} c^{\mathrm{TG}-\mathrm{CMV}}\end{array}$ & Mitigates gonadal tumor progression and prevents cachexia & Gold et al. 2013 \\
\hline
\end{tabular}


Activins and Inhibins

Table 2. Continued

\begin{tabular}{|c|c|c|c|c|}
\hline \multicolumn{2}{|c|}{ Genotypes } & \multicolumn{2}{|r|}{ Phenotypes } & References \\
\hline \multicolumn{2}{|c|}{$\begin{array}{l}\text { Inha }{ }^{-/-} \\
\qquad h p g / h p g\end{array}$} & \multicolumn{2}{|c|}{$\begin{array}{l}\text { Disrupted ovarian folliculogenesis with arrest at the } \\
\text { primary antral stage; male and female hypogonadism and } \\
\text { sterility; suppression of gonadal/adrenal tumors and } \\
\text { cachexia; immature seminiferous tubule-like structures in } \\
\text { testes and ovaries }\end{array}$} & Kumar et al. 1996 \\
\hline \multicolumn{2}{|c|}{$\begin{array}{l}\text { Inha }{ }^{-/-} \\
\qquad \text { Gdf } 9^{-/-}\end{array}$} & \multicolumn{2}{|c|}{$\begin{array}{l}\text { Follicles progress to the multilaminar stage with } \\
\text { nonsteroidogenic theca layer }\end{array}$} & $\begin{array}{l}\text { Wu et al. 2004; } \\
\text { Myers et al. } 2013\end{array}$ \\
\hline \multicolumn{2}{|c|}{ Genotypes } & Site of inactivation & Phenotypes & References \\
\hline \multicolumn{5}{|c|}{ Conditional knockouts } \\
\hline \multirow{2}{*}{\multicolumn{2}{|c|}{$\begin{array}{l}\text { Amhr2-Cre; } \\
\quad \text { Inhba } a^{\text {flox } /-} \\
\text { Amhr2-Cre; } \\
\quad \text { Inhba flox/- }\end{array}$}} & $\begin{array}{l}\text { Ovarian granulosa } \\
\text { cells }\end{array}$ & $\begin{array}{l}\text { Disruption results in } 35 \% \text { reduction in female } \\
\text { fertility }\end{array}$ & Pangas et al. 2007 \\
\hline & & Fetal Leydig cells & $\begin{array}{l}\text { Failure of fetal testis cord elongation and } \\
\text { expansion, decreased Sertoli cell } \\
\text { proliferation, smaller adult testes, regional } \\
\text { testicular dysgenesis, and reduced sperm } \\
\text { production }\end{array}$ & $\begin{array}{l}\text { Archambeault and } \\
\text { Yao } 2010\end{array}$ \\
\hline \multicolumn{2}{|c|}{$\begin{array}{l}\text { Amhr2-Cre; } \\
\qquad \begin{array}{l}\text { Inhba } a^{\text {flox/-- }} \\
\text { Inhbb }\end{array}\end{array}$} & $\begin{array}{l}\text { Ovarian granulosa } \\
\text { cells }\end{array}$ & $\begin{array}{l}\text { Female infertility; increased functional } \\
\text { corpora lutea }\end{array}$ & Pangas et al. 2007 \\
\hline \multicolumn{2}{|c|}{$\begin{array}{l}\text { Krt14-Cre; } \\
\quad \text { Acvr1bflox/flox }\end{array}$} & Skin epithelium & $\begin{array}{l}\text { Variable hairlessness as a result of defects in } \\
\text { hair cycling and hair-follicle development }\end{array}$ & Qiu et al. 2011 \\
\hline Genes & Expression & Promoters & Phenotypes & References \\
\hline \multicolumn{5}{|c|}{ Gain-of-function } \\
\hline \multicolumn{5}{|c|}{ Activins and inhibins } \\
\hline Inhba & Testis & Metallothionein & Testicular degeneration & $\begin{array}{l}\text { Tanimoto et al. } \\
1999\end{array}$ \\
\hline Inhba & Epidermis & Keratin 14 & $\begin{array}{l}\text { Small body size, small ears and short tail, } \\
\text { severe epidermal thickening, loss of } \\
\text { subcutaneous adipose }\end{array}$ & Munz et al. 1999b \\
\hline Inhba & Epidermis & Keratin 14 & $\begin{array}{l}\text { Enhanced skin tumorigenesis and } \\
\text { malignancy, differential effects on T-cell } \\
\text { proliferation }\end{array}$ & $\begin{array}{l}\text { Antsiferova et al. } \\
2011\end{array}$ \\
\hline Inhba & Forebrain & $\alpha \mathrm{CaMKII}$ & Reduced anxiety-related behavior & Ageta et al. 2008 \\
\hline Inhba & Forebrain & Tet-off inducible & $\begin{array}{l}\text { Effects on long-term potentiation and } \\
\text { maintenance of long-term memory }\end{array}$ & Ageta et al. 2010 \\
\hline $\operatorname{Inhbc}$ & Widespread & CMV promoter & $\begin{array}{l}\text { Male infertility, large inflamed liver, } \\
\text { prostatic hypertrophy with epithelial } \\
\text { hyperplasia }\end{array}$ & Gold et al. 2009 \\
\hline $\operatorname{Inhbc}$ & Liver & Plasmid transfer & $\begin{array}{l}\text { Inhibits regenerative DNA synthesis in } \\
\text { mouse liver after volume overload injury }\end{array}$ & $\begin{array}{l}\text { Chabicovsky et al. } \\
2003\end{array}$ \\
\hline $\operatorname{Inhbc}$ & Liver & $\begin{array}{l}\text { Adenovirus } \\
\text { transfer }\end{array}$ & $\begin{array}{l}\text { Accelerates liver regeneration after partial } \\
\text { hepatectomy in rats }\end{array}$ & Wada et al. 2005 \\
\hline Inhbe & Widespread & CMV- $\beta$ actin & $\begin{array}{l}\text { Reduced pancreatic weight, adipose } \\
\text { replacement of pancreatic acini with } \\
\text { islets preserved }\end{array}$ & $\begin{array}{l}\text { Hashimoto et al. } \\
2006\end{array}$ \\
\hline Inhbe & Liver & Plasmid transfer & $\begin{array}{l}\text { Inhibits regenerative DNA synthesis in } \\
\text { mouse liver after volume overload injury }\end{array}$ & $\begin{array}{l}\text { Chabicovsky et al. } \\
2003\end{array}$ \\
\hline
\end{tabular}


M. Namwanje and C.W. Brown

Table 2. Continued

\begin{tabular}{|c|c|c|c|c|}
\hline Genes & Expression & Promoters & Phenotypes & References \\
\hline Inha & Widespread & Metallothionein & $\begin{array}{l}\text { Female subfertility because of reduced FSH } \\
\text { levels; ovarian cysts, abnormal } \\
\text { steroidogenesis, reduced testicular size }\end{array}$ & $\begin{array}{l}\text { Cho et al. 2001; } \\
\text { McMullen et al. } \\
2001\end{array}$ \\
\hline Inha & $\begin{array}{l}\text { Several tissues } \\
\text { including } \\
\text { gonads }\end{array}$ & Metallothionein & $\begin{array}{l}\text { FSH reduced, LH increased; females } 52 \% \\
\text { reduction in litter size; reduced } \\
\text { ovulation; } 50 \% \text { reduction in sperm } \\
\text { count but normal fertility }\end{array}$ & Cho et al. 2001 \\
\hline Inha & Liver & Inducible & $\begin{array}{l}\text { Reduced testis size and block in ovarian } \\
\text { folliculogenesis at early antral stage; } \\
\text { reduced FSH levels; rescue of the } \\
\text { Inha }{ }^{-/-} \text {phenotype }\end{array}$ & Pierson et al. 2000 \\
\hline \multicolumn{5}{|c|}{ Activin/inhibin receptors, binding, and regulatory proteins } \\
\hline Acvrlb & Epidermis & Keratin 14 & Delayed wound re-epithelialization & $\begin{array}{l}\text { Bamberger et al. } \\
2005\end{array}$ \\
\hline Fst & Liver, testis & Metallothionein & $\begin{array}{l}\text { Leydig cell hyperplasia, infertility in males } \\
\text { and females, thin uteri, small testes and } \\
\text { ovaries, disheveled fur }\end{array}$ & Guo et al. 1998 \\
\hline Fst288 & $\begin{array}{l}\text { Normal Fst } \\
\text { expression } \\
\text { pattern }\end{array}$ & Targeted insertion & $\begin{array}{l}\text { Fst knockin allele is sufficient for survival } \\
\text { but results in female subfertility and } \\
\text { premature ovarian follicle depletion }\end{array}$ & Kimura et al. 2010 \\
\hline Fst288 & $\begin{array}{l}\text { Normal Fst } \\
\text { expression } \\
\text { pattern }\end{array}$ & $\begin{array}{l}\text { Fst regulatory } \\
\text { sequences }\end{array}$ & $\begin{array}{l}\text { Fst } 288 \text { expression does not rescue the } \\
\text { neonatal lethality of } F s t^{-/-} \text {mice }\end{array}$ & Lin et al. 2008 \\
\hline Fst315 & $\begin{array}{l}\text { Normal Fst } \\
\text { expression } \\
\text { pattern }\end{array}$ & $\begin{array}{l}\text { Fst regulatory } \\
\text { sequences }\end{array}$ & $\begin{array}{l}\text { Rescue of } F s t^{-/-} \text {phenotype; female } \\
\text { infertility, cystic ovaries, aberrant } \\
\text { corpora lutea, uterine hypoplasia/ } \\
\text { inflammation, and distal vascular } \\
\text { abnormalities }\end{array}$ & Lin et al. 2008 \\
\hline
\end{tabular}

hepatectomy, suggesting a possible role in the inhibition of hepatocyte proliferation (Esquela et al. 1997; Zhang et al. 1997; Gold et al. 2005; Takamura et al. 2005); however, adenoviral expression of activin $\mathrm{C}$ in cultured hepatocytes also enhances proliferation (Wada et al. 2005), whereas transient, low-level expression of either activin $\mathrm{C}$ or activin $\mathrm{E}$ in mouse liver inhibits regenerative DNA synthesis (Chabicovsky et al. 2003). Moreover, activin C can either increase DNA synthesis or induce apoptosis in vitro depending on the cell type. Neither activin $\beta C$ nor $\beta \mathrm{E}$, alone or in combination, however, is required for fertility or development, growth, regeneration, and function of the liver in vivo (Lau 2000). Thus, the cellular context (normal cells versus transformed cells, or tissue of origin), differences in the relative proportions of bioavailable activins, and differences in experimental conditions are all factors that may contribute to the disparate outcomes. Studies in prostate tumor, pituitary cell lines, and transgenic mice suggest that activin $\mathrm{C}$ antagonizes activin A signaling (Gold et al. 2009).

\section{Activin Receptors}

There are overlapping and unique functions for the two type II activin receptors, ActRII, and ActRIIB. This is perhaps best illustrated during embryonic development, as inactivating either receptor results in a different phenotype. Acvr2 $2^{-/-}$mice have small mandibles and cleft palates, reminiscent of the Pierre Robin sequence in humans (Matzuk et al. 1995b). Adult males have reduced fertility and females are in- 
fertile. In contrast, $A c v r 2 b^{-/-}$mice display defects in left-right and anteroposterior axis determination (Oh and Li 1997).

\section{Smad2 and Smad3}

Smad2 and Smad3, which transduce signals from several TGF- $\beta$ family members, including activins, have overlapping and unique functions. Smad2 null mice display early embryonic lethality as a result of a dosage-sensitive spectrum of defects, which include failure of normal egg cylinder and germ layer formation, with or without mesoderm and severe gastrulation defects. Some heterozygotes have abnormalities in ocular and mandibular development (Nomura and Li 1998; Waldrip et al. 1998). In contrast, Smad3 null mice are viable and fertile, but have metabolic disturbances and ultimately develop colorectal cancer (Zhu et al. 1998; Yadav et al. 2011). Additional features include accelerated cutaneous wound healing with faster re-epithelialization and reduced local inflammation (Ashcroft et al. 1999) and defects in T-cell mediated and mucosal immunity (Yang et al. 1999). The difference in phenotypic severity between Smad2 and Smad3 null mutants is likely a result, in part, of differences in spatiotemporal expression during development; however, functional differences in tissues in which the two proteins are coexpressed have also been observed. Smad2 and Smad3 play distinct roles in the testis, because activin-induced nuclear Smad accumulation is greatly influenced by the developmental stage of Sertoli cells as well as the activin concentration, reflected by different transcriptional outcomes (Itman et al. 2009). Thus, specific control mechanisms are likely to be in place to direct the use of phosphorylated Smad2 and Smad3 in this context.

\section{Inhibins}

Mice with targeted disruption of the inhibin $\alpha$ subunit expression (Inha- $\mathrm{I}^{--}$), lack of inhibins $\mathrm{A}$ and $\mathrm{B}$ with a consequential increase in activin signaling. These mice do not have birth defects, but instead develop gonadal and adrenal tumors, a cancer-cachexia phenotype, loss of acid-producing parietal cells in the stomach, and hepatocellular necrosis.

\section{Activins and Development in Other Model Organisms}

\section{Morphogen Gradients and Signaling from a Distance in Xenopus laevis and Drosophila melanogaster}

Mechanisms that establish morphogen gradients of TGF- $\beta$ family signaling and their roles in patterning during early embryonic development have been well studied (Green and Smith 1990; Kessler and Melton 1995; Lecuit et al. 1996; Nellen et al. 1996; Gurdon and Bourillot 2001). An important paradigm is that cells respond differently depending on the ligand concentration to which their receptors are exposed, thereby initiating different transcriptional cascades and developmental outcomes. In dissociated Xenopus animal cap cells, activin binds to ActRII and ActRIIB, and has downstream effects that are concentration-dependent. The switch in gene expression profile occurs at $2 \%-6 \%$ receptor occupancy (Dyson and Gurdon 1998). This effect depends on the absolute number of receptors that are occupied by ligand per cell, and not by the ratio of occupied to unoccupied receptors (Dyson and Gurdon 1998). These studies provided insight into the mechanisms by which activin morphogen gradients might contribute to differential gene expression and, consequently, developmental patterning.

It is less clear whether activin establishes a gradient by diffusion from its source, thus decreasing in concentration more than several cell diameters, or whether a relay mechanism occurs, whereby cells sequentially send distinct signals to adjacent cells.

In support of the diffusion model, activin can elicit a cellular response at least 10 cell diameters away in experiments using Xenopus embryo reconstituted tissue explants (Gurdon et al. 1994). This effect persisted even when protein synthesis was inhibited in the intermediate endothelial cells that were incapable of activin responsiveness, arguing against a cell-to-cell re- 
lay mechanism (Gurdon et al. 1994). Also in support of the diffusion model, fluorescently labeled activin travels through the extracellular spaces of reconstituted Xenopus animal cap cells. The range of signaling activity from the activin source is inversely proportionate to the number of activin receptors on the cell surface, and activin signal transduction in these cells does not require endocytosis of activin-receptor complexes (Hagemann et al. 2009).

A simple diffusion model is perhaps insufficient, however, to explain how morphogens might overcome deterrents, such as the extracellular matrix and functionally antagonistic proteins to travel several cell diameters. Experiments in intact Xenopus blastula cells, as opposed to dissociated and reconstituted cells, support a relay model in which adjacent cells but not more distant ones are capable of ligand-induced signal transduction, a process that includes production of secondary, distinct signals (Reilly and Melton 1996).

In the Drosophila wing disc, cells that are incapable of mediating endocytosis and, therefore, unable to transduce ligand-induced signaling are also incapable of establishing a Decapentaplegic (Dpp) gradient (Lecuit et al. 1996). Other experiments examining Dpp functions indicate that simple diffusion and at least one other (possible relay) mechanism may contribute to establishing morphogen gradients (Lecuit et al. 1996). An extension of the relay model posits that morphogen gradients are established with the aid of cytonemes. Cytonemes are specialized signaling filopodia that extend outward from the cytoplasmic membrane of recipient cells to direct cell-to-cell transfer of secreted ligands. Although cytoneme-mediated ligand transfer has been clearly shown for Dpp in the Drosophila wing disc (Roy et al. 2014), to our knowledge this phenomenon has not been documented for activins or other TGF- $\beta$ family ligands in Drosophila or in vertebrates.

\section{Activin Signaling in Drosophila Melanogaster}

A variety of developmental processes, which include cell proliferation and growth, neuronal remodeling, axon guidance, and dorsal neuron morphogenesis, occur through activin-like signaling pathways in Drosophila (Zheng et al. 2003, 2006; Parker et al. 2006; Serpe and O'Connor 2006). Activin- $\beta$ and Dawdle (Daw) are two activin/TGF- $\beta$-like ligands (Parker et al. 2004; Serpe and O'Connor 2006). In contrast to vertebrates, both BMP and activin/TGF- $\beta$ pathways use common type II receptors, Punt and Wishful Thinking (Wit), whereas the activin pathway specificity is conferred by the type I receptor, Baboon (Babo), which signals through Smad2 (Smox [Smad on X]) (Das et al. 1999; Zheng et al. 2003; Serpe and O'Connor 2006). The diversity of type I/type II receptor combinations in Drosophila is considerably less than vertebrates, providing an important tool to dissect the contributions of activin/TGF- $\beta$ - and BMP-signaling pathways.

\section{PHYSIOLOGICAL FUNCTIONS OF ACTIVINS AND INHIBINS}

\section{Reproduction}

Activins and inhibins were originally characterized as activators or inhibitors, respectively, of pituitary FSH production and release. The gonads are the major sources of circulating activins and inhibins that provide regulatory feedback to the pituitary, and function as autocrine and paracrine signals that control gonadal function. Conversely, activin and inhibin expression are regulated by endocrine signals that originate in the pituitary. Accordingly, a discussion of the reproductive roles of activins and inhibins requires an understanding of their relationship to the hypothalamic-pituitary-gonadal (HPG) axis (Fig. 5).

\section{The HPG Axis}

The anterior pituitary shows cellular heterogeneity, producing a variety of hormones, including FSH and LH. LH and FSH are heterodimeric proteins with the same $\alpha$ subunit but different $\beta$ subunits, produced by pituitary gonadotropes. The expression and release of LH and FSH are primarily regulated by $\mathrm{GnRH}$ that is produced by the hypothalamus, which receives 
input from gonadal signals that include inhibins, estrogen, progesterone, and testosterone (Fig. 5A). GnRH is released into a dense capillary plexus, then passes to the adjacent anterior pituitary gland to control the release of $\mathrm{LH}$ and $\mathrm{FSH}$, influenced by the pulse frequency of GnRH release (Kaiser et al. 1995; Sealfon et al. 1997; Shacham et al. 2001; Burger et al. 2002). Pituitary activin B expression is also controlled by the GnRH pulse frequency (Burger et al. 2002). GnRH expression in the hypothalamus and $\mathrm{GnRH}$ receptors on pituitary gonadotropes is enhanced by activins, and blocked by follistatin (Fig. 5A) (Fernandez-Vazquez et al. 1996; Norwitz et al. 2002).

$\mathrm{LH}$ and FSH $\beta$ subunit expression is regulated by activins and inhibins. Activin B from the anterior pituitary has paracrine effects on gonadotropes, enhancing GnRH-induced FSH expression and release (Fig. 5A) (Corrigan et al. 1991). Similarly, activin A augments GnRH-induced LH production and is antagonized by testosterone (Burger et al. 2003; Yamada et al. 2004; Coss et al. 2005). Inhibin B produced by the gonads plays an important role in the feedback mechanisms that regulate the HPG axis (Fig. 5B,C). Inhibin B and follistatin antagonize many of the aforementioned functions of the activins (Wang et al. 1988; Kaiser et al. 1992; Winters et al. 1996; Burger et al. 2002).

\section{Activins and Inhibins in Female Reproduction}

Inhibin $\mathrm{B}$, the major circulating form of inhibin in several animal species, originates from the ovary, as confirmed by markedly reduced plasma levels after gonadectomy (Robertson et al. 1988; Woodruff et al. 1996). It regulates the HPG axis primarily through suppressive effects on activin-mediated FSH expression and release, but also through direct effects in the ovary, impacting ovarian folliculogenesis, steroidogenesis, and the menstrual cycle (Figs. 5 and 6) (Hsueh et al. 1987; McLachlan et al. 1987; Woodruff et al. 1988, 1990; Lenton et al. 1991; Groome et al. 1996).

Activins and inhibins play important autocrine and paracrine roles during several steps of ovarian folliculogenesis (Fig. 6). With each ovarian cycle, follicles are recruited from a primordial pool, and subsequently progress from a single oocyte surrounded by a single layer of epithelial cells to a much larger oocyte surrounded by several layers of granulosa, theca, and stromal cells. This heterogeneous, multicellular structure provides a supportive hormonal environment for folliculogenesis and the early stages of pregnancy.

Activin A contributes to the breakdown of germ cell nests, a process that increases the primordial follicle pool, thereby increasing fertility potential (Fig. 6A) (Bristol-Gould et al. 2006). One or both of the circulating forms of follistatin antagonize this effect (Kimura et al. 2011). Activin and other proteins within and outside the TGF- $\beta$ family help to drive the early stages of follicular growth, before the contribution of FSH signaling at the early pre-antral stage (Fig. 6B,C) (Trombly et al. 2009). Expression of FSH receptors in granulosa cells of multilayer follicles is essential for normal folliculogenesis. Inhibin antagonizes expression of FSH receptors and has several important functions during the late stages of folliculogenesis. The antral follicle has an abundance of steroidogenic cells that work together to produce and release estrogen. The antral granulosa cells also produce inhibins, with inhibin B the major circulating form. Estrogen production is stimulated by FSH, and pituitary expression of FSH is ultimately down-regulated by circulating inhibin B from ovarian follicles in a negative feedback loop. Inhibin production by granulosa cells is also stimulated by FSH (Hillier et al. 1991a). Inhibin augments $\mathrm{FSH}$-induced estrogen production in granulosa cells and LH-induced androgen production in theca cells (Hillier et al. 1991b; Wrathall and Knight 1995). Androgens are converted to estrogen by granulosa cell aromatase. Inhibin also slows the maturation of oocytes at the antral follicle stage (Fig. 6D) (Silva et al. 1999). Although variable numbers of primordial follicles are recruited for folliculogenesis during each ovarian cycle, only a subset of follicles ultimately proceeds to ovulation. The process of "follicular dominance" is supported in part by activin and antagonized by inhibin (Fig. 6E) (Hillier and Miro 1993). After ovulation, the 
M. Namwanje and C.W. Brown
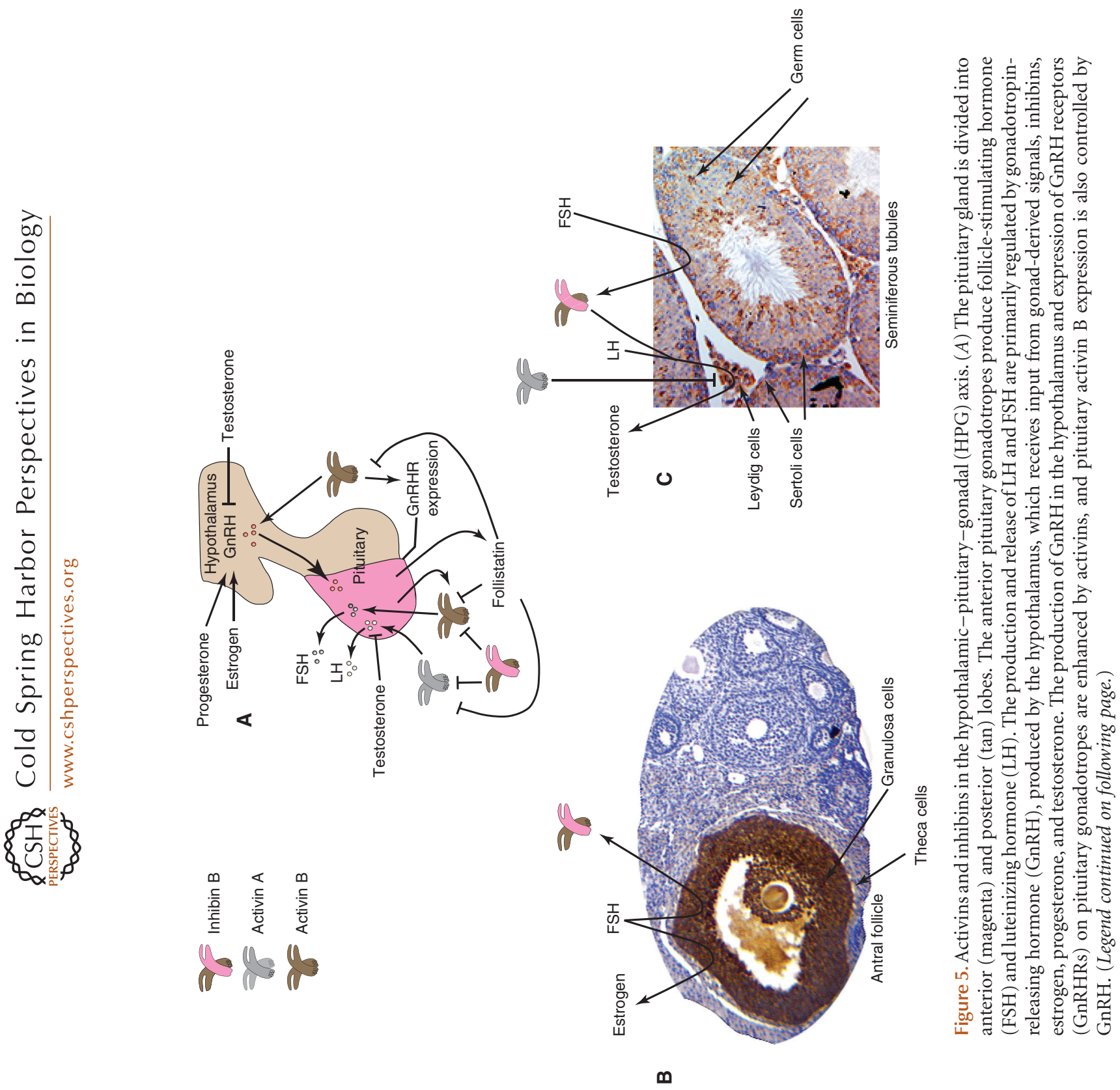
remaining follicular cells coalesce to form the corpus luteum, whose major function is LHinduced progesterone production to support the early stages of pregnancy. Inhibin is also produced by the corpus luteum at high levels throughout the luteal phase of the ovarian cycle (Fig. 6F) (Roberts et al. 1993).

During the ovarian cycle, granulosa cells differentially express activin and inhibin monomers (Fig. 6G). Activin $\beta$ subunits are expressed at very low levels in early-stage follicles. Activin $\beta \mathrm{A}$ is most abundant in late antral follicles and in corpora lutea, whereas expression of activin $\beta B$ is restricted to small antral follicles. The inhibin $\alpha$ subunit is expressed throughout the ovarian cycle, increasing in mature follicles and corpora lutea. All type I and type II activin receptors, betaglycan, and follistatin are expressed in all cell types and at all stages of folliculogenesis (Roberts et al. 1993; Welt and Schneyer 2001; Drummond et al. 2002; Knight and Glister 2006). However, circulating levels of inhibins do not correspond to the levels of expression in granulosa cells. Quickly rising levels of inhibin A can be detected during ovulation and peak levels in the midluteal phase. In contrast, inhibin B shows a biphasic pattern with peak levels at the early follicular and early luteal phases (Fig. 6G) (Groome et al. 1996; Woodruff et al. 1996; Welt 2004).
Important functional roles for activins and inhibins during pregnancy are strongly suspected because circulating activin levels are very low or undetectable under normal physiological conditions except during pregnancy when inhibin, activin, and follistatin levels, likely all of fetal and placental origin, progressively rise and markedly increase during the third trimester (Fig. 6H) (Muttukrishna et al. 1995; O'Connor et al. 1999). Follistatin levels are higher than activin levels throughout pregnancy, whereas basal levels of inhibin are high and decrease slightly before a rapid increase between 25 and 30 weeks gestation. Although the biological roles during pregnancy are unclear, abnormally low maternal inhibin levels are associated with pregnancy loss and other complications (Muttukrishna 2004), whereas abnormally increased activin levels in late pregnancy are associated with pre-eclampsia, preterm labor, and gestational diabetes (Petraglia et al. 1995a,b; Gallinelli et al. 1996).

In cultured granulosa cells from early-stage follicles, FSH stimulates the release of inhibin and estrogen (Fig. 7A) (Hillier et al. 1991a). Inhibin augments FSH-induced estrogen production while inhibiting the expression of FSH receptor (Campbell and Baird 2001; Lu et al. 2009). In contrast, activin A enhances the expression of estrogen receptors and in-

Figure 5. (Continued) The LH and FSH $\beta$ subunits are primary targets for regulation by activins and inhibins. Activin B (brown-colored icon) from the anterior pituitary exerts paracrine effects on gonadotropes, enhancing GnRH-induced FSH production and release. Similarly, activin A (gray-colored icon) augments GnRH-induced LH production, antagonized by testosterone. Activin also enhances the expression of GnRH receptors on gonadotropes, an effect that is blocked by follistatin. Inhibin B (brown-pink icon) produced by the gonads plays an important role in feedback mechanisms that regulate the HPG axis, as inhibin B and follistatin antagonize many functions of activins. $(B)$ The antral follicle contains steroidogenic cells that collaborate to produce and release estrogen. The granulosa cells produce estrogen and inhibins, driven by pituitary FSH, with inhibin B the major circulating form. FSH expression is ultimately repressed by circulating inhibin B from ovarian follicles in a negative feedback loop. Activin $\beta$ A immunostaining (brown) shows abundant expression restricted to the granulosa cells of a single, large antral follicle, but not in follicles at earlier stages (CW Brown, unpubl.). (C) The seminiferous tubules are comprised of germ cells, Sertoli cells, Leydig cells, and other cells. All activin and inhibin subunits, activin receptors, betaglycan and follistatin are expressed in the testis, and their expression is controlled by the stage of the seminiferous cycle, age and pubertal stage, and cell type. Activin $\beta \mathrm{A}$ immunostaining (brown) in this adult testis section is apparent in Leydig cells, Sertoli cells and germ cells at more than one stage of development (CW Brown, unpubl.). Inhibin B (brown-pink icon) is the only inhibin produced by the testis and the major circulating form. In Sertoli cells, FSH stimulates inhibin B production, providing negative feedback for pituitary FSH production, whereas LH induces the production of androgens from rodent Leydig cells, a process that is augmented by inhibin and attenuated by activin (gray icon). 

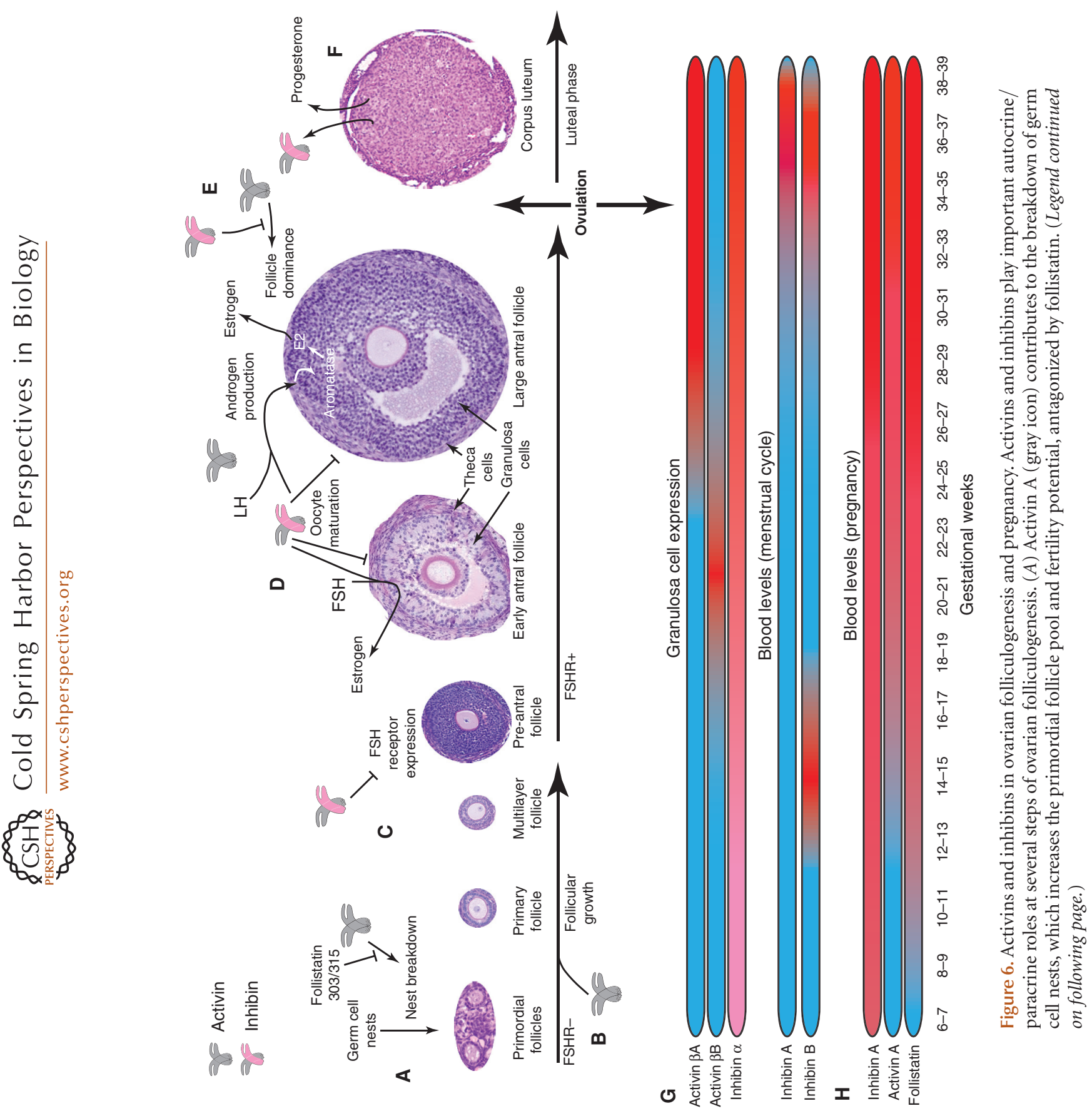
creases DNA replication, an effect that is augmented by FSH (Rabinovici et al. 1990; Miro and Hillier 1996; Kipp et al. 2007). In cultured theca cells, activin suppresses LH-induced androgen production, whereas inhibin augments androgen production and antagonizes activin's suppressive effect (Fig. 7B) (Hillier et al. 1991b). In cultured luteal cells, activin suppresses $\mathrm{LH}$-induced progesterone synthesis, whereas inhibin antagonizes activin's effects (Fig. 7C) (Rabinovici et al. 1990; Di Simone et al. 1994).

Genetic approaches to understand the roles of inhibins in reproduction have been confounded by the gonadal tumors that develop in complete inhibin-deficient mice (Matzuk et al. 1992). Nevertheless, some insight has been gained from other inhibin mouse models. Transgenic mice that widely overexpress inhibin $\alpha$ show subfertility with a $52 \%$ decrease in litter size, and have reduced LH and FSH levels, ovarian cysts, abnormal steroidogenesis, and a reduced number of ovulated oocytes (Cho et al. 2001; McMullen et al. 2001). Mifepristone-induced expression of inhibin $\alpha$ in the liver of adult mice blocks ovarian folliculogenesis at the early antral stage (Pierson et al. 2000).

GDF-9 is a TGF- $\beta$ family member whose expression is restricted to oocytes. Ovaries from $G d f 9^{-/-}$mice display an arrest in follicu- logenesis at the primary follicle stage, with normal oocyte growth and zona pellucida development, but no progress in the growth of the surrounding follicular cells beyond the singlelayer stage (Dong et al. 1996). In contrast, $\mathrm{Gdf9}^{-/-}$; Inha ${ }^{-/-}$mice have ovarian follicles that progress to the multilaminar stage before the appearance of inhibin-related sex cord stromal tumors (Matzuk et al. 1992), but the theca layer is incapable of steroid production ( $\mathrm{Wu}$ et al. 2004; Myers et al. 2013). Therefore, inhibins are negative regulators of early follicular development and might contribute to the function of theca cells.

In contrast to the normal fertility of Inhbb ${ }^{-/-}$mice (Vassalli et al. 1994), conditional inactivation of Inhba in developing ovarian granulosa cells reduces female fertility by $\sim 38 \%$ (Pangas et al. 2007). Conditional loss of one Inhba allele in an Inhbb ${ }^{-1-}$ genetic background reduces fertility by $90 \%$, and complete loss of activins A and B in granulosa cells causes infertility (Pangas et al. 2007). These findings suggest overlapping, dosage-sensitive functions for activins A and B during ovarian folliculogenesis, with activin A playing a predominant role. Accordingly, female fertility is severely impaired in $I n h b a^{\text {BK }}$ mice, in which Inhba is replaced with a functionally hypomorphic activin $\beta \mathrm{B}$ al-

Figure 6. (Continued) (B) Activin contributes to early stages of follicular growth. (C) Expression of the folliclestimulating hormone (FSH) receptor in granulosa cells of multilayer follicles is required for folliculogenesis. Inhibin (gray-pink icon) antagonizes FSH receptor expression in granulosa cells. $(D)$ Inhibin enhances FSHinduced estrogen production in granulosa cells, and luteinizing hormone ( $\mathrm{LH}$ )-induced androgen production in theca cells, whereas androgen production is antagonized by activin (gray icon). Androgens are converted to estrogen (E2) by aromatase in granulosa cells. Inhibin also slows the maturation of oocytes at the antral follicle stage. (E) Although variable numbers of primordial follicles are recruited for folliculogenesis during each ovarian cycle, only a few will proceed to ovulation. The process of "follicular dominance" is supported by activin and antagonized by inhibin. $(F)$ After ovulation, the remaining follicular cells coalesce to form the corpus luteum, whose major function is LH-induced progesterone production to support the early stages of pregnancy. Inhibin is also produced by the corpus luteum at high levels throughout the luteal phase of the ovarian cycle. $(G)$ Granulosa cell expression and blood levels of activin and inhibin in the context of the ovarian cycle are shown, with low levels in blue and high levels in red. Activin $\beta$ subunits are expressed at very low levels in early-stage follicles. Activin $\beta \mathrm{A}$ is most abundantly expressed in late antral follicles and in corpora lutea, whereas activin $\beta B$ is restricted to small antral follicles. The inhibin $\alpha$ subunit is expressed throughout the ovarian cycle, increasing in mature follicles and corpora lutea. However, circulating levels of inhibins do not correlate with the levels of expression in granulosa cells. Inhibin A levels increase rapidly during ovulation and peak in the midluteal phase. In contrast, inhibin B has a biphasic pattern with peak levels at the early follicular and early luteal phases. $(H)$ During pregnancy, inhibin, activin, and follistatin levels progressively increase, and markedly increase during the third trimester. Follistatin levels are greater than activin levels throughout pregnancy, whereas basal inhibin levels are higher and decrease slightly before the rapid increase between 25 and 30 weeks gestation. 
M. Namwanje and C.W. Brown
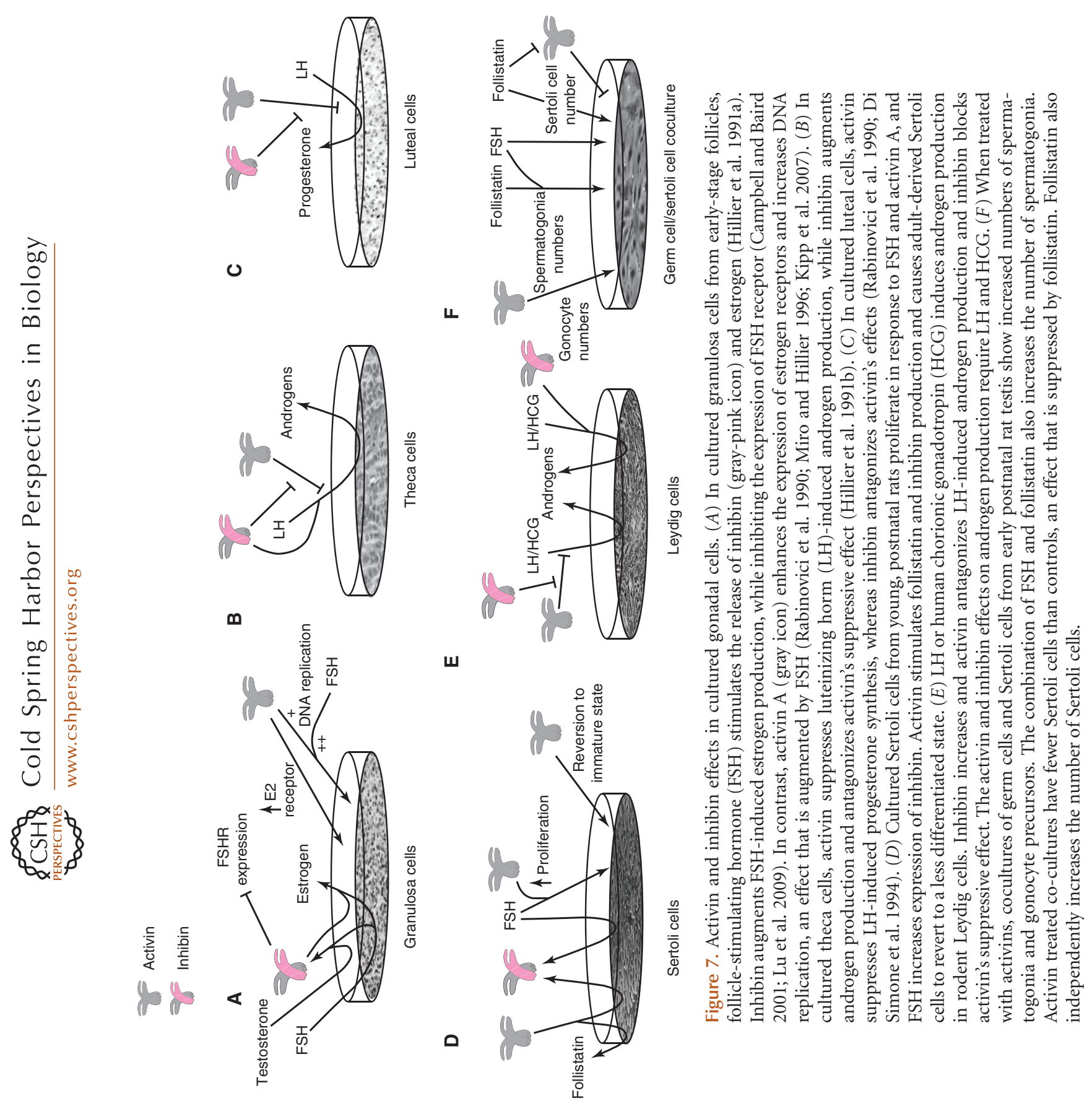
lele (Brown et al. 2000). The ovaries of $\operatorname{Inhba^{\mathrm {BK}}}$ mice are smaller and contain fewer large preantral follicles than controls. Serum estrogen and progesterone levels are reduced. Thus, activin B can partially replace activin $\mathrm{A}$ as an ovarian growth and maintenance factor, but is insufficient to fully maintain all aspects of ovarian folliculogenesis.

Transgenic mice that overexpress follistatin have thin uteri, small ovaries with defective folliculogenesis, and subfertility, dependent on the level of transgene expression (Guo et al. 1998), and show many similarities to mice with reduced activin signaling. Female transgenic mice that only express Fst315 are infertile as a result of abnormal corpus luteum formation, cystic ovaries and hypoplastic, inflamed uteri. In contrast to transgenic mice that overexpress the Fst288 isoform on a Fst ${ }^{-/}$background and die as newborns, mice with a Fst288 insertion allele are viable, but homozygous females are subfertile with excess primordial follicles as a result of a greater number of germ cells and reduced rate of apoptosis. These mice subsequently develop ovarian failure as a result of premature follicle depletion (Kimura et al. 2010, 2011).

Transgenic mice that overexpress human FSTL3 from an inhibin $\alpha$ promoter show high expression in the gonads. The mice have lower body mass up to 2 months of age. Females have smaller ovaries with fewer large pre-ovulatory follicles, occasional trapped oocytes in corpora lutea, and a 35\% reduction in litter size. These features are similar to those of the transgenic mice expressing follistatin and mice that are activin-deficient in granulosa cells, and suggest possible overlapping functions for follistatin and FSTL-3 in reproduction. Taken together, the findings in the FSTL3 transgenic mice are consistent with important roles for activins in gonadal development and gametogenesis (Xia et al. 2004).

The control of mRNA expression of BAMBI in adult rat gonads suggests potential roles in reproduction with high expression in granulosa and theca cells from adult ovaries. However, $\mathrm{Bambi}^{-/-}$mice are viable, fertile and without developmental or reproductive defects. There- fore, $\mathrm{BAMBI}$ is not essential for normal female reproduction (Chen et al. 2007).

\section{Activins and Inhibins in Male Reproduction}

The seminiferous tubules are comprised of germ cells, Sertoli cells, Leydig cells, and other cell types. Sertoli cells provide a supportive environment for spermatogenesis, and Leydig cells synthesize androgens. Collectively, all activin and inhibin subunits, activin receptors, betaglycan, and follistatin are produced by testis cells, and their expression patterns are influenced by the stage of the seminiferous cycle in adults and the age and pubertal status of the animal. These expression characteristics create a complex, dynamic autocrine and paracrine regulatory network (MacConell et al. 2002; Buzzard et al. 2004; Riccardi et al. 2007). Inhibin $\mathrm{B}$ is the only form of inhibin produced by the testis and is also the major circulating inhibin (Illingworth et al. 1996; Marchetti et al. 2003). FSH stimulates inhibin B expression in Sertoli cells, providing negative feedback for pituitary FSH production (Sharpe et al. 1999; Hayes et al. 2001), whereas LH induces the production of androgens from rodent Leydig cells, a process that is augmented by inhibin and attenuated by activin (Hsueh et al. 1987), although these effects may be species-dependent (Lejeune et al. 1997).

Cultured Sertoli cells from postnatal (P6, P9) rats proliferate in response to FSH or activin $A$, and the effects on proliferation are additive (Fig. 7D) (Buzzard et al. 2003). FSH also induces the expression of inhibin $B$ and free inhibin $\alpha$ subunit precursor, pro- $\alpha \mathrm{C}$. The latter reduces inhibin B bioactivity and likely plays an important regulatory role (Grootenhuis et al. 1990; Hancock et al. 1992). Activin stimulates follistatin and inhibin A and B production and can induce reversion of adult-derived Sertoli cells to a less differentiated state in vitro (Buzzard et al. 2003; Nicholls et al. 2012).

LH or the closely related human chorionic gonadotropin (HCG), which also binds and activates the LH receptor, induces androgen production from cultured rodent Leydig cells (Fig. $7 \mathrm{E})$. Inhibin increases and activin antagonizes 
LH-induced androgen production (Hsueh et al. 1987; Mauduit et al. 1991), and inhibin blocks activin's suppressive effect (Lin et al. 1989). It is unclear whether the antagonism of activin signaling by inhibin is the sole mechanism by which inhibin enhances LH-induced androgen secretion. However, no activin or inhibin effects on androgen production occur in the absence of LH/HCG.

When treated with activin $\mathrm{A}$ or $\mathrm{B}$, cocultures of germ and Sertoli cells from early postnatal rat testis fragments give rise to increased numbers of spermatogonia and gonocyte precursors, followed by formation of seminiferous tubule-like structures, suggesting that activins provide important signals that direct the positional organization of cells in the developing testis (Fig. 7F) (Mather et al. 1990). The combination of FSH and follistatin also increases the number of spermatogonia. Conversely, activin-treated cocultures have fewer Sertoli cells than untreated control cultures, an effect that is suppressed by follistatin. Follistatin also independently increases Sertoli cell number. In this coculture system, inhibin is unable to block the activin effect (Meehan et al. 2000).

The process of compartmentalization in the prenatal testis causes formation of the testis cord and the surrounding interstitium. Sertoli cells produce signals to direct testis cord formation. Activin A is produced by mouse fetal Leydig cells and acts on Sertoli cells to promote proliferation during late embryogenesis. Silencing activin A expression specifically in fetal Leydig cells causes failure of fetal testis cord elongation and expansion because of decreased Sertoli cell proliferation, a finding reproduced by the conditional silencing of Smad4 expression in fetal Sertoli cells. In mice with absence of activin $\beta A$ or Smad4 in fetal Leydig or Sertoli cells, respectively, testicular dysgenesis persists to adulthood, with abnormal testis histology and reduced sperm counts. These findings support a model in which activin A produced by Leydig cells during early development acts on Sertoli cells to stimulate proliferation (Archambeault and Yao 2010).

Male Inhba ${ }^{\mathrm{BK}}$ mice are fertile but their testicular volumes are greatly diminished, and the onset of fertility is later than normal because of developmental effects on Sertoli cell proliferation and delayed germ cell maturation (Brown et al. 2000; Mendis et al. 2010; Mithraprabhu et al. 2010). Adult Inhba ${ }^{\mathrm{BK}}$ testis histology is normal; however, seminiferous tubule maturation is delayed and the dosage and biopotency of the Inhba alleles correlate directly with testicular size. Inhba $a^{-/-}$newborn testes are also very small, attributed to the reduced proliferation of Sertoli cells (Mendis et al. 2010). These studies confirm that activin A signaling is required for normal prenatal and postnatal testicular growth, and its function cannot be replaced entirely by activin $\mathrm{B}$.

Transgenic, testis-restricted overexpression of activin $\beta$ A postnatally results in progressive sterility because of testicular degeneration (Tanimoto et al. 1999). In contrast, transgenic mice that widely overexpress follistatin have reduced testis volume with Leydig cell hyperplasia, arrest of spermatogenesis and seminiferous tubule degeneration leading to infertility (Guo et al. 1998), while adult transgenic male mice that express only Fst315 are fertile (Kimura et al. 2010, 2011). Mice with transgenic overexpression of inhibin $\alpha$ have a $50 \%$ reduction in sperm count but normal fertility (Cho et al. 2001; McMullen et al. 2001). Mice with induced expression of inhibin $\alpha$ in liver also have reduced testis size (Pierson et al. 2000). Thus, transgenic mice overexpressing follistatin or inhibin have findings that are consistent with activin deficiency.

Transgenic male mice that overexpress human FSTL3 from the inhibin $\alpha$ promoter also have lower testis volumes with $\sim 60 \%$ reduction in sperm count, because of irregular seminiferous tubule degeneration with selective loss of germ cells in several tubules, relative preservation of Sertoli cells, Leydig cell hyperplasia and abnormal testosterone production. Collectively, these abnormalities are associated with a $25 \%$ reduction in litter size. The findings in FSTL3 transgenic mice are consistent with important roles for activins in maintaining testicular function and gametogenesis (Xia et al. 2004).

The high level of BAMBI expression in several cell types in adult male rat testes suggests 
potential roles for BAMBI in reproduction. BAMBI is expressed in juvenile and adult Sertoli cells, and its expression in germ cells greatly increases as gonocytes mature into spermatogonia shortly after birth. Exogenous activin A decreases the Bambi mRNA level in cultures of newborn rat testis fragments. Thus, BAMBI was predicted to contribute to the control of TGF- $\beta$ family signaling at several stages of gametogenesis (Loveland et al. 2003). However, Bambi ${ }^{-/-}$ males are also viable, fertile, and without identifiable developmental or reproductive defects (Chen et al. 2007).

\section{Erythropoiesis}

Activin A was first recognized for its role in erythropoiesis when conditioned media of human leukemic THP-1 cells was seen to induce differentiation of mouse erythroleukemic Friend cells (Eto et al. 1987). Several studies of murine and human bone marrow cells and erythroleukemic cell lines show that activin A robustly induces erythroid differentiation, with increased colonies of erythroid burst forming units (BFU-E), erythroid colony forming units (CFU-E) and an increase in hemoglobin production. These responses to activin require EPO and are sensitive to concentrations of activin and EPO (Yu et al. 1987; Murata et al. 1988; Shiozaki et al. 1992, 1998; Maguer-Satta et al. 2003). In vivo activin A administration also increases BFU-E and CFU-E colonies in a dosagedependent manner in normal or anemic mice (Shiozaki et al. 1989).

Activin A and activin receptors are expressed in human bone marrow cells (Maguer-Satta et al. 2003; Wu et al. 2012). Activin $A$ induces the expression of EPO receptor, $\beta$-globin, $p 27^{K i p 1}$ and $B c l-X L$ and decreases the expression of Gata2 (Maguer-Satta et al. 2003). One of the models for the role of activin signaling in erythropoiesis suggests a synergism between activin A and EPO to promote commitment and differentiation of erythroid precursors more than apoptosis. ELM-I-1 mouse leukemic cells show a twofold increase in hemoglobin-positive cells in cultures when treated with activin A and EPO, relative to treatments with either alone (Shiozaki et al. 1998). However, F5-5 mouse leukemia cells with a constitutively active EPO receptor are unaffected by $\mathrm{EPO}$, while treatment with activin A or activin $\mathrm{A}$ and EPO increases the number of hemoglobin-positive cells (Shiozaki et al. 1998). Furthermore, ELM-I-1 cells treated with activin A alone were apoptotic when compared with cells treated with EPO and activin A, a phenomenon that was not observed in F5-5 cells (Shiozaki et al. 1998). Together, these results suggest that activin A commits erythroid precursors to the erythroid lineage but requires EPO to suppress apoptosis and possibly to regulate cell-cycle mediators that allow activin-induced differentiation to proceed (Shiozaki et al. 1998).

During erythropoiesis, activin A is regulated by follistatin and inhibin. In vitro and in vivo studies have shown that treatment with either follistatin or inhibin A or cotreatment of follistatin or inhibin A with activin A reduces BFU$\mathrm{E}$ and CFU-E colony formation and hemoglobin accumulation, even in the presence of EPO (Yu et al. 1987; Shiozaki et al. 1992; MaguerSatta et al. 2003).

\section{The Nervous System}

Activins and inhibins are widely expressed in the brain. Activin $\beta A$ and $\beta B$ subunits are expressed in neuronal cell bodies in the nucleus of the solitary tract and in the dorsal and ventral medullary reticular nuclei, which control pain sensation and some components of the autonomic nervous system. Activins are also expressed in the nerve fibers and the termini of projection sites for these nuclei. Activin B immunoreactivity is observed in perifornical neurons of the hypothalamus, which include orexin-producing cells, whereas activin A is present in neuronal cell nuclei scattered throughout the central nervous system. Transcripts encoding all inhibin/activin subunits are present in all major brain regions (Roberts et al. 1996). Similarly, type II activin receptors are widely expressed in the rat brain with highest mRNA levels in the hippocampus, amygdala, hypothalamus, and throughout the cortical mantle, including the primary olfactory cortex 
M. Namwanje and C.W. Brown

(Cameron et al. 1994). Thus, there is potential for wide-ranging activin effects in the brain.

Activin A treatment of embryonic day 18 rat retinal cultures arrests proliferation and induces differentiation of progenitor cells into rod photoreceptors (Davis et al. 2000). The effect is specific to the rod photoreceptor lineage and is dose-dependent. Mice lacking activin A show a decrease in rod photoreceptors (Davis et al. 2000). Blocking activin signaling in Drosophila embryos by abrogating activin- $\beta$, Daw, Babo, or Smox results in larvae with small brains and aberrant photoreceptor axon targeting (Zhu et al. 2008). The ligands activin $\beta$ and Daw show functional redundancy in these contexts. Together, these results suggest that activin signaling is required not only for differentiation of rod photoreceptors in the retina, but also for producing the proper number of neurons to enable normal connection of photoreceptor axons to their targets.

Activins are also neuronal survival factors and this effect is brain region-selective. Activin increases the survival of multipotent P19 teratoma cells, the rat B50 nerve cell line and chick neural retinal cells (Schubert et al. 1990). Activin $A$ and $B$ are neuroprotective against serum deprivation and toxin-induced death of human neuroblastoma cells. Transient expression of activin $\beta \mathrm{A}$ or $\beta \mathrm{B}$ protects neuroblastoma and rat pheochromocytoma cells against serum withdrawal-induced apoptosis. Activin A also protects cultured E14 rat mesencephalic dopaminergic cells from $\mathrm{N}$-methyl-4-phenylpiridinium ion toxicity (Krieglstein et al. 1995).

Transgenic mice that express a dominantnegative ActRIB (ALK-4) from the CaMKII- $\alpha$ promoter in the forebrain have hippocampal neurons that are more sensitive to intracerebroventricular excitotoxic insult. Glutamatergic neurotransmission is also affected, with reduced $N$-methyl-D-aspartate-induced current response and impaired long-term potentiation (Hughes et al. 1999). In a chemically induced rat model of Huntington disease produced by excitotoxic striatal injection, intrastriatal injections of activin A greatly reduced the degeneration of several populations of striatal neurons of rats. The most potent protective ef- fect was observed in the striatal cholinergic interneuron population, comprised of striatal interneurons and projection neurons (Hughes et al. 1999). Consistent with these observations, intraventricular administration of human activin A reduced neuronal death in the hippocampus and dorsolateral striatum induced by hypoxic-ischemic brain injury ( $\mathrm{Wu}$ et al. 1999). Activin A also supports the survival of rat hippocampal neurons in vitro (Iwahori et al. 1997).

Activin B plays an important developmental role in spinal cord where TGF- $\beta 1$ and activin B cooperate to support oligodendrocyte development and myelination (Dutta et al. 2014). Oligodendrocytes produce myelin, the material that surrounds axons and promotes nerve conduction. Cultured oligodendrocyte precursors (OLP) show differential activation of Smad3 and MAPK signaling in response to TGF- $\beta 1$ and activin B. TGF- $\beta 1$ increases proliferation while activin B supports maturation. Treatment with both proteins has an additive effect on viability, and enhances proliferation and differentiation, thus increasing the number of mature oligodendrocytes (Dutta et al. 2014). The spinal cords of $I n h b b^{-/-}$embryos display increased apoptosis in the oligodendrocyte lineage and transiently reduced OLP numbers, but cell numbers, maturation, and myelination recover during the first postnatal week. These findings suggest a functional redundancy with other TGF- $\beta$ family ligands in this process, a contention supported by a more severe and prolonged OLP phenotype in Smad3 ${ }^{-/-}$mice (Dutta et al. 2014).

$\mathrm{Bambi}^{-/-}$mice are viable, fertile, and without identifiable developmental defects (Chen et al. 2007), but show increased TGF- $\beta$ signaling and broadly reduced acute and chronic pain responses. The pain tolerance is reversed by naloxone, an opioid antagonist, through a mechanism involving $\delta$-opioid receptor signaling. Proopiomelanocortin (POMC) and proenkephalin (PENK) are increased in the spinal cords of $\mathrm{Bambi}^{-/-}$mice, and treatment of wild-type spinal cord explants with activin A or BMP-7 increases POMC and/or PENK mRNA levels (Tramullas et al. 2010). These findings are con- 
sistent with a role for activin signaling in the control of pain sensitivity.

\section{Energy Metabolism \\ Adipocyte Differentiation}

Activins A and B and their receptors are highly expressed in rat and mouse adipose tissues and adipogenic cells (Vejda et al. 2002; Kogame et al. 2006; Allen et al. 2008; Hoggard et al. 2009; Koncarevic et al. 2012). In humans, the highactivin $\beta A$ mRNA expression in preadipocytes is even higher in adipose tissues from obese individuals. However, activin A mRNA levels decrease when human preadipocytes are induced to differentiate, and exogenous activin A protein inhibits adipogenesis while increasing proliferation of preadipocytes by decreasing the expression of the early adipogenic transcription factor CCAAT/enhancer binding protein$\beta$ (C/EBP- $\beta)$, thereby arresting adipogenesis. Activin A inhibits C/EBP- $\beta$ through Smad2 signaling (Zaragosi et al. 2010), whereas inhibition by TGF- $\beta 1$ is transduced through Smad3 (Choy et al. 2000; Tsurutani et al. 2011). Similar outcomes were observed in undifferentiated mouse 3T3-L1 preadipocytes, in which activin $\mathrm{A}$ increased cell proliferation and reduced expression of C/EBP- $\alpha$ and peroxisome proliferator-activated receptor $\gamma(\operatorname{PPAR} \gamma)$, the "master regulator” of adipogenesis (Hirai et al. 2005).

\section{Mature Adipocyte Function}

Activin $\beta A$ and $\beta B$ are expressed in adipose tissues but their abundance differs. Activin $\beta A$ expression is higher in undifferentiated preadipocytes (Hirai et al. 2005; Zaragosi et al. 2010), whereas activin $\beta B$ expression is higher in differentiated 3T3-L1 adipocytes and in human adipose tissue. Differentiated 3T3-L1 cells treated with insulin or dexamethasone have increased or decreased activin $\beta B$ expression, respectively. Activin $\beta B$ expression is also reduced in leptin-deficient mice after administration of leptin, but no leptin effect is observed in differentiated 3T3-L1 cells (Hoggard et al. 2009).

In mice and humans, activin $\beta \mathrm{B}$ mRNA levels in white adipose correlate positively with obesity (Sjöholm et al. 2006; Hoggard et al. 2009). Diet-induced weight loss reduces $I n h b b$ gene expression in obese humans (Sjöholm et al. 2006). Moreover, Inhbb $b^{-/-}$mice have lower body weights than wild-type controls (Bonomi et al. 2012). In differentiated 3T3-L1 cells, treatment with activin B reduces expression of perilipin, hormone-sensitive lipase and adipose triglyceride lipase, important contributors to lipolysis (Magnusson et al. 2010). Thus, activin A and activin B likely play different roles in adipogenesis and mature adipocyte function.

The $I n h b a^{\mathrm{BK}}$ mice described above have reduced body weight and adiposity with improved insulin sensitivity and increased energy expenditure ( $\mathrm{Li}$ et al. 2009). These mice are resistant to the obesogenic effects of a high-fat, high-carbohydrate diet. The improved metabolic outcomes are attributed to increased expression of genes involved in energy expenditure, mitochondrial biogenesis, and function in brown adipose tissue, liver, and skeletal muscle. Isolated liver mitochondria show constitutive oxygen consumption as a result of uncoupling of oxidative phosphorylation, suggesting a role for activin signaling in supporting mitochondrial function (Li et al. 2009).

\section{Activin Signaling in Glucose Homeostasis}

Activins $\mathrm{A}$ and $\mathrm{B}$ are expressed in adult rodent pancreatic islet cells, with activin A in $\alpha$-islet cells and activin B in $\alpha$ - and $\beta$-islet cells (Yasuda et al. 1993; Brown et al. 2011). In humans, activin A levels in serum correlate with fasting glucose, fasting insulin, and glycosylated hemoglobin levels (Wu et al. 2013). Loss- and gainof-function transgenic mouse models for activins, activin receptors, FSTL-3, and Smads have contributed to our understanding of activin signaling in pancreas development and the proliferation, differentiation and function of islet cells (reviewed in Wiater and Vale 2012). Transgenic expression of a dominant negative ActRIIB or a constitutively active ALK-4 receptor in the pancreas results in islet hypoplasia with reduced insulin secretion and reduced glucose tolerance (Yamaoka et al. 1998). In a mouse model of pancreas regeneration, inhibition of 
activins by follistatin increases the proliferation of epithelial cells in the pancreatic duct and reduces insulin secretion, most likely by reducing the differentiation of $\beta$-islet cells (Zhang et al. 2004). In contrast, Fstl $3^{-/-}$mice show increased pancreatic islet number and size, pancreatic $\beta$-cell hyperplasia, lower visceral fat mass, beneficial effects on glucose homeostasis, liver fat accumulation, and mild hypertension. Despite the ability of FSTL-3 to inhibit myostatin, however, $\mathrm{Fstl}^{-/-}$mice show no changes in lean body mass or body weight. Collectively, the findings have been attributed to effects of unsuppressed activin and/or myostatin activity (Mukherjee et al. 2007). The reduction of $\beta$ cell mass with streptozotocin or by partial pancreatectomy, results in increased expression of activins in the pancreatic duct, and increased insulin and glucose levels (Zhang et al. 2002). The increased expression of activins in the pancreatic duct after partial pancreatectomy suggests that they may contribute to $\beta$-cell neogenesis. Although the factors that regulate activin effects in the duct are not well understood, $\beta$-cell regeneration may occur by relief of transcriptional repression of neogenin 3 through non-Smad signaling (Ogihara et al. 2003).

In the Inhba ${ }^{\mathrm{BK}}$ model, with enhanced insulin sensitivity, our understanding of activin effects on glucose metabolism is confounded by possible systemic effects of activin-B misexpression in activin-A-producing tissues (Brown et al. 2000). Acvrlc ${ }^{-/-}$null mice lacking the ALK-7 receptor are hyperinsulinemic and glucose-intolerant, and have increased islet mass. This is partly because of reduced activin B signaling (Bertolino et al. 2008). However, other ligands, such as activin $\mathrm{A}$, activin- $\mathrm{AB}, \mathrm{GDF}-3$, and nodal, also use the ALK-7 receptor so the loss of signaling by one or more of these ligands should also be considered (Tsuchida et al. 2004; Bertolino et al. 2008; Zhao et al. 2012).

Studies on effects of activins on glucose homeostasis have produced disparate results in vivo and in vitro. In Drosophila, the activinlike ligand, Daw, maintains glucose homeostasis mediated by Smad signaling. The daw mutants have increased triglycerides, glycogen, and glucose levels, and these abnormalities are rescued by overexpressing daw selectively in the fat body. Gene expression profiling in daw mutants revealed up-regulation of several genes encoding enzymes and other proteins that participate in fatty acid oxidation, Krebs cycle, and oxidative phosphorylation (Ghosh and O'Connor 2014).

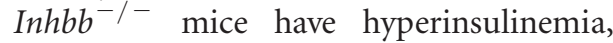
glucose intolerance, and insulin resistance, similar to ALK-7-deficient mice. Islets from Inh $b b^{-/-}$mice secrete more insulin and generate more ATP on glucose stimulation, and both processes are reversed after treatment with activin B (Wu et al. 2014). Although activins A and $B$ share common signaling mechanisms, they may have unique functions in glucose homeostasis. Treatment of islets with activin $B$ reduces the influx of calcium ions, insulin secretion, and ATP production after glucose stimulation, whereas activin A has the opposite effect (Bertolino et al. 2008; Wu et al. 2014). The differences in insulin secretion are a result of the selective phosphorylation of Smad2 by activin $A$ and Smad3 by activin B that may have different downstream targets and divergent outcomes on glucose stimulation (Wu et al. 2014). Another study of Inhbb ${ }^{-/-}$mice, however, showed no effect on insulin secretion, insulin sensitivity or glucose tolerance (Bonomi et al. 2012). Additionally, Inhbb $b^{-/-}$mice had lower body weights, pancreatic islet mass and a lower $\alpha$ to $\beta$-islet cell ratio (Bonomi et al. 2012); however, a different study found no differences in body weight or pancreatic islet mass at age 2 months (Wu et al. 2014). The difference in genetic background of the mice may explain the conflicting results: a mixed 129/Sv-C57BL/6 background in one study and a backcrossed C57BL/ 6 background in the other.

Irrespective of these differences, insight has been provided from both studies regarding the pancreatic islet distribution of activins and the different effects of activins A and B on insulin secretion. Ectopic expression of activin B in the Inhba ${ }^{\mathrm{BK}}$ model results in reduced fasting glucose and insulin levels and enhanced insulin sensitivity and glucose tolerance, suggesting that increased expression of activin B in pancreatic islets may contribute to the enhanced glucose metabolism in this mouse model (Li et al. 2009). 


\section{Bone Homeostasis}

Activin A mRNA expression by osteoblasts and activin A deposition in the bone matrix are higher than $I n h b b$ expression, while inhibin $\alpha$ mRNA is nearly undetectable (Ogawa et al. 2006; Eijken et al. 2007; Wu et al. 2012). Studies of activin A and inhibin A effects on bone development and function have yielded contradictory results. Injection of activin A into newborn rat periosteum increases periosteal and bone matrix layer thickness (Oue et al. 1994). Intramuscular injection of activin A improves bone mass and strength in aged, ovariectomized rats (Sakai et al. 2000). Soluble ActRIIA-mFC inhibits activin signaling but also increases bone formation, mass, and strength in sham-operated and ovariectomized mice, possibly by affecting signaling of other TGF- $\beta$ family ligands (Pearsall et al. 2008). Treatment of bone marrow-derived stem cells with activin A promotes osteoblastogenesis and osteoclastogenesis, while inhibin A has the opposite effect (Centrella et al. 1991; Fuller et al. 2000; Gaddy-Kurten et al. 2002). Activin A can also inhibit osteoblastogenesis and mineralization in vitro, dependent on the differentiation stage (Ikenoue et al. 1999; Eijken et al. 2007). These results highlight the importance of considering the proper window of responsiveness to activins for osteoblastogenesis, a process that is also regulated by follistatin (Hashimoto et al. 1997; Eijken et al. 2007).

Transgenic mice with mifepristone-induced overexpression of inhibin $\alpha$ in liver have increased bone mineral density, volume, and strength as a consequence of increased osteoblastogenesis and show reversal of gonadectomy-induced bone loss (Perrien et al. 2007). These results seemingly contradict those from in vitro studies, and the disparate outcomes could be explained by compensatory mechanisms in vivo or by differences in the duration of inhibin exposure, since 1-week exposure in vivo inhibits osteoblastogenesis as observed in vitro, whereas 4 weeks overexpression augments osteoblastogenesis and enhances bone quality. Similar to activin A, these results suggest that inhibin A regulates osteoblastogenesis to prime osteoblast precursors for differentiation (Perrien et al. 2007).

In humans, serum inhibin A and inhibin B levels correlate negatively with bone-formation markers in peri- and postmenopausal women and, therefore, can be used as clinical predictors of bone loss before detectable changes in estrogen levels (Perrien et al. 2006).

\section{Inflammation}

Activins play early roles in a variety of inflammatory processes (Jones et al. 2004; Werner and Alzheimer 2006; Phillips et al. 2009; BessonFournier et al. 2012), and many cells conferring innate and acquired immunity respond to activins (Antsiferova and Werner 2012).

\section{Macrophages}

During inflammation, macrophages show different activation states and biological activities (Mantovani et al. 2004). Lipopolysaccharide (LPS) and interferon- $\gamma$ induce a classical proinflammatory (M1) macrophage profile, whereas interleukin (IL)-4 or IL-13 induce an antiinflammatory activation state (M2a) with production of immunosuppressive factors, IL10, IL-1RA (IL-1 receptor antagonist), and arginase (Martinez et al. 2008). Activin A, but not activin B, expression is increased in LPS-stimulated macrophages (Ogawa et al. 2006).

Effects of activin A in the RAW264.7 mouse macrophage cell line include increased IL-1 $\beta$ and IL-6 expression, pinocytosis and phagocytosis, and MHC II expression, but no enhanced expression of MHC I markers and CD80, and no effect on proliferation, suggesting that activin A may affect macrophage-mediated innate and acquired immune responses through macrophage activation (Ge et al. 2009).

M1, but not M2a macrophages, derived from human peripheral blood monocytes, release activin $\mathrm{A}$, and $\mathrm{Smad}$ /3-mediated activin signaling supports the M1 macrophage phenotype, contributing to differential gene expression profiles and functions of the M1 and M2a phenotypes. Activin A suppresses IL-10 production by mature, antiinflammatory $\mathrm{M} 2 \mathrm{a}$ macrophages, to inhibit IL-10 production dur- 
ing polarization and to inhibit the growth of leukemic cells, a defining feature of M1-polarized macrophages (Sierra-Filardi et al. 2011).

The proinflammatory M1 phenotype of human monocyte-derived macrophages requires activin A induction of EGLN3, an oxygen-dependent prolyl hydroxylase whose expression is associated with the M1 macrophage phenotype in a variety of inflammatory conditions, such as Crohn's disease, ulcerative colitis, and solid tumors. EGLN3 expression is induced by hypoxia and additionally regulated by activin signaling (Escribese et al. 2012). These studies establish important functions for activin A in macrophage biology and are consistent with its contributions to inflammatory processes.

\section{Other Inflammatory Processes and Cell Types}

Macrophages are not the only hematopoietic cells that participate in activin-regulated inflammatory processes. Bone marrow-derived neutrophil precursors (BMNPs) express activin $A$ at seven-fold higher levels than mononuclear cells. Tumor necrosis factor $\alpha$ (TNF- $\alpha$ ) induces activin A release from BMNPs without de novo synthesis, an effect that is blocked by insulin, suggesting a possible mechanistic link to inflammatory processes in type 2 diabetes ( $\mathrm{Wu}$ et al. 2013). In contrast, through a different mechanism, LPS has no effect on BMNPs, but stimulates activin A expression and release in total bone marrow cultures (Wu et al. 2013).

In vivo, bone marrow is a major source of circulating activin A after LPS-induced inflammation. Similar to total bone marrow cultures, the increase in activin A is posttranscriptional. This is in contrast to TNF- $\alpha$ and follistatin responses to inflammation, which are transcriptionally regulated. The activin-A-producing cells are bone marrow-derived neutrophils that migrate to the lung and may contribute to LPS-induced lung inflammation and injury (Savov et al. 2002; Wu et al. 2012).

Studies of chronic inflammatory mechanisms that contribute to anemia of chronic disease have revealed an unusual example of promiscuity among activin ligands and receptors. During LPS-induced inflammation, acti- vin $B$ expression is selectively increased in mouse liver (Besson-Fournier et al. 2012), an effect that is not seen for the other activins. Activin B induces BMP type I receptor-mediated combined Smad 1/5/8 phosphorylation (Smads were not assessed individually) in a human hepatoma cell line and primary mouse hepatocytes, resulting in increased Hamp (hepcidin) mRNA levels (Besson-Fournier et al. 2012). This activin-B-induced increase occurs synergistically with IL-6. These hepcidin effects are not observed with the other activins, showing that, despite overlapping functions in many contexts, activins $\mathrm{A}$ and $\mathrm{B}$ also have unique functions that may be transduced by the BMP branch of Smad-mediated TGF- $\beta$ family signaling.

\section{Adipose Tissue Inflammation and Metabolism}

Obesity is characterized by low-grade inflammation. In mice and humans, the expression of inflammatory genes increases with obesity (Hotamisligil et al. 1993, 1995; Engström et al. 2003). Inflammatory cytokines are secreted by immune cells, particularly adipose resident macrophages (Weisberg et al. 2003; Cancello et al. 2005). T cells are also recruited and contribute to the inflammatory milieu (Wu et al. 2007; Feuerer et al. 2009; Winer et al. 2009). Obesity results in recruitment of M1 macrophages to adipose tissues, and also triggers M2 to M1 adipose-resident macrophage conversion (Lumeng et al. 2007, 2008), with higher levels of secreted activin A in M1 than in M2 macrophages (Sierra-Filardi et al. 2011). Proinflammatory cytokines secreted by macrophages inhibit differentiation of preadipocytes (Lacasa et al. 2007; Xie et al. 2010). Activin A inhibits adipocyte differentiation in human and mouse cells (Hirai et al. 2005; Zaragosi et al. 2010), and human preadipocytes cultured in conditioned media from adipose-resident macrophages show increased Inhba mRNA expression (Zaragosi et al. 2010). These data are consistent with a model in which activated macrophages in white adipose tissues produce inflammatory cytokines, possibly including activin $\mathrm{A}$, creating an environment that antagonizes adipocyte differentiation. 


\section{Chronic Lung Disease}

Activin A may participate in airway remodeling, and activin signaling dysregulation may contribute to the normal balance between immunity and tolerance in the airway and asthma in mice and humans (reviewed in Kariyawasam et al. 2011). Activin has shown both beneficial and damaging effects, promoting the growth of airway epithelium and suppressing inflammation in some contexts, while augmenting inflammation, fibrosis, and lung damage in others.

Protective effects for activin were shown in a mouse model of allergic asthma, a process requiring TGF- $\beta$ and mediated by regulatory Tcell (T-reg) activation that normally suppresses the $\mathrm{T}$ helper cell immune response (Semitekolou et al. 2009). Activin A levels and signaling in lung tissues normally acutely increase in response to allergens; however, activin signaling is later reduced, partially by follistatin. In a mouse model of allergy-induced asthma, follistatin blocks mucus production and the allergen-specific immune response in lymph nodes (Hardy et al. 2006). Follistatin also reduces airway inflammation and improves survival in a mouse model of cystic fibrosis (Hardy et al. 2015). Moreover, blocking activin signaling in a bleomycin-induced lung injury model substantially reduces the inflammatory and fibrotic effects of the drug (Aoki et al. 2005). These findings are consistent with a biphasic response to inflammatory stimuli in the lung - an acute phase with increased activin signaling that promotes epithelialization and subsequent suppression that minimizes potentially damaging effects of inflammation. This process is dysregulated in the asthmatic airway, leading to chronic inflammation. Disparate effects among experimental models likely reflect the complexity of the mechanism and the different conditions for administration of irritants, activins, and follistatin.

\section{BIOLOGICAL ROLES IN RESPONSE TO INJURY AND DISEASE}

Wound Healing

Activin A expression increases in skin after injury and promotes wound healing (Hübner et al. 1999). Transgenic overexpression of activin $A$ in the skin results in adipose replacement with fibrous connective tissue, a poorly organized, thick epidermis and enhanced proliferation of basal keratinocytes. Injury causes enhanced dermal fibrosis with granulation tissue and robust scar formation. Activins $\beta A$ and $\beta B$ normally increase in keratinocytes and stroma after skin injury in mice and humans. All activin receptors are expressed in skin and their levels do not change after injury (Hübner et al. 1996). Recombinant activin B stimulates healing, requiring signaling through the RhoA-JNK pathway (Zhang et al. 2011), and mice expressing a dominant negative ActRIB (ALK-4) receptor in keratinocytes show delayed re-epithelialization after skin injury (Bamberger et al. 2005). Keratinocyte-selective abrogation of follistatin greatly enhances re-epithelialization (Antsiferova et al. 2009), whereas transgenic expression of follistatin in keratinocytes causes thinning of the epidermis and dermis and delayed wound repair, but less scarring (Wankell et al. 2001b). Inhibiting activin signaling in the developing zebrafish fin causes failure of normal fin regeneration after amputation, supporting important roles in proliferation, cell migration, and wound healing (Jazwinska et al. 2007). This finding is also consistent with previously described roles for activins in the developing chick limb (Merino et al. 1999).

\section{Fibrosis}

Activins contribute to hepatic, renal, and pulmonary fibrosis. In rats with liver fibrosis, activin A is expressed by collagen-producing, stellate-derived myofibroblasts in connective tissue septae (De Bleser et al. 1997). Follistatin administration during carbon tetrachloride-induced liver fibrosis reduces hepatocyte apoptosis and collagen accumulation (Patella et al. 2006). The profibrotic effects of activin A on hepatic stellate cells in vitro are also mitigated by follistatin (Wada et al. 2004).

In the kidney, activin A participates in the response to ischemic injury, which includes expression in medullary tubules (Maeshima et al. 2002). Follistatin protects against ischemic in- 
jury and preserves renal function in vivo, whereas activin A has the opposite effect (Maeshima et al. 2002). Rat kidney fibroblasts, but not renal tubule epithelial cells, express type I collagen and smooth muscle actin when treated with activin A (Yamashita et al. 2004), and cultured rat renal mesangial cells express extracellular matrix proteins when treated with activin A (Gaedeke et al. 2005).

Several medical conditions result in increased activin A expression in the lungs of patients with interstitial pulmonary fibrosis (Matsuse et al. 1996). In vitro studies show that activin A enhances the proliferation of lung fibroblasts, induces their differentiation into myofibroblasts and enhances their ability to contract collagen gels (Ohga et al. 1996, 2000). Moreover, bleomycin-induced lung injury and fibrosis is mitigated by administration of follistatin (Aoki et al. 2005).

In summary, in vitro and in vivo experiments suggest roles for activin signaling in the pathogenesis of fibrosis in a variety of tissues and cell types. Most data corroborate the observation that activin expression increases during acute inflammatory processes, which leads to profibrotic events. Moreover, in vitro experiments show activin-induced up-regulation of a variety of profibrotic factors, including inflammatory cytokines and extracellular matrix components.

\section{Cancer}

Activin inhibits the proliferation of breast, liver, prostate, and pancreatic carcinoma cell lines and pituitary adenomas. Many malignant cell types repress the expression of activin receptors, while activins promote the proliferation of cells from testis and ovary (reviewed in Risbridger et al. 2001, 2004). Activins can also indirectly support tumor growth by inducing angiogenesis and by affecting the tumor microenvironment, influencing dendritic cell number and antigen uptake. Elevated circulating activin A is associated with bone metastases in breast and prostate cancer (Leto et al. 2006; Incorvaia et al. 2007), and increased activin A expression in head and neck tumors is associated with poor prognosis for overall and disease-free survival (Chang et al. 2010). Soluble ActRIIB-Fc, an inhibitor of activin signaling, reverses cancerinduced cachexia and improves survival in mice (Zhou et al. 2010).

Activin A overexpression in skin increases susceptibility to chemically induced skin cancer because of effects on stromal cells and loss of antitumor T-cell function. T-reg cells ( $\mathrm{T}$ cells that normally suppress the function of tumorsuppressing $\mathrm{T}$ cells) increase in number in chemically treated activin transgenic mice. The net result of activin A overexpression in this model, therefore, is reduced T-cell antitumor activity and tumor progression (Antsiferova et al. 2011). Taken together, these data suggest a biphasic role for activin, first as an inhibitor of cell proliferation and tumor growth, and later as a promoter of oncogenesis, similar to the actions of TGF- $\beta$ (reviewed in Akhurst and Hata 2012).

Inha ${ }^{-1-}$ mice with targeted inactivation of inhibin $\alpha$ expression, display early lethality at 12 weeks because of gonadal tumors, hepatocellular injury and a cancer cachexia syndrome. Gonadectomized mice survive longer but succumb to adrenal cortical tumors. Therefore, inhibins are gonadal and adrenal tumor suppressors. Several genes are modifiers of the Inha $a^{-1-}$ phenotype (Table 2) (Matzuk et al. 1995a; Coerver et al. 1996; Kumar et al. 1996, 1999; Mishina et al. 1996; Shou et al. 1997; Cipriano et al. 2000, 2001; Burns et al. 2003a,b; Li et al. 2007; Nagaraja et al. 2008; Zhou et al. 2010; Gold et al. 2013). With the exception of $\mathrm{AMH}, \mathrm{AMHRII}$ and $\mathrm{p} 27^{\mathrm{KIP} 1}$, which repress the cancer cachexia syndrome, the double mutants have milder phenotypes than the Inha ${ }^{-1-}$ mice, thereby identifying coregulatory processes that influence tumor progression. Collectively, these findings suggest that dysregulated activin signaling contributes to cancer and cachexia, that cachexia and tumor progression are not indelibly linked, and that other signaling pathways and cell-cycle proteins influence inhibin-related cancer progression. The cachexia of Inha ${ }^{-/-}$mice is mediated at least in part by the type II activin receptors, ActRII and ActRIIB, because genetic inactivation (Coerver 
et al. 1996) or inhibition (Zhou et al. 2010) of these receptors can block Inha ${ }^{-/-}$-induced cachexia.

\section{THERAPEUTIC INITIATIVES TO TARGET ACTIVIN-SIGNALING PATHWAYS: ANTIBODIES, RECEPTOR-BASED LIGAND TRAPS AND MODIFIED PRODOMAINS}

\section{Disorders of Energy Metabolism}

\section{Obesity}

In addition to physical exercise and diet-modification, new drugs aim to treat obesity and its associated morbidities by targeting specific sig- naling pathways. Targeting the activin-signaling pathways has promising therapeutic potential to influence lean/fat body mass and energy expenditure. Inhibiting ActRIIB using neutralizing antibodies or modified soluble human receptors (ActRIIB-hFc) positively influences body composition and nutrient metabolism (Table 3) (Akpan et al. 2009; Fournier et al. 2012; Koncarevic et al. 2012; Zhang et al. 2012). Administering soluble ActRIIB (RAP031) improves muscle mass and function, reduces fat mass irrespective of diet composition, enhances peripheral glucose uptake, and suppresses hepatic glucose production. Mice treated with ActRIIB neutralizing antibody have in-

Table 3. Therapeutic strategies to inhibit activin receptor signaling

\begin{tabular}{|c|c|c|c|}
\hline Disease model & Agent & Benefits & References \\
\hline \multicolumn{4}{|l|}{ Neutralizing antibody } \\
\hline $\begin{array}{l}\text { Obesity/energy } \\
\text { metabolism (mouse) }\end{array}$ & $\begin{array}{l}\text { Anti-ActRIIB } \\
\text { monoclonal } \\
\text { antibody }\end{array}$ & $\begin{array}{l}\text { Increased brown adipose and } \\
\text { skeletal mass; no effect on } \\
\text { white adipose }\end{array}$ & Fournier et al. 2012 \\
\hline \multicolumn{4}{|c|}{ Ligand traps (soluble receptors) } \\
\hline $\begin{array}{l}\text { Obesity/energy } \\
\text { metabolism (mouse) }\end{array}$ & $\begin{array}{l}\text { ActRIIB-hFc (RAP- } \\
\text { 031); sActRIIB }\end{array}$ & $\begin{array}{l}\text { Increased muscle mass and } \\
\text { function; increased glucose } \\
\text { uptake; reduced fat-mass and } \\
\text { britening of white adipose }\end{array}$ & $\begin{array}{l}\text { Akpan et al. 2009; } \\
\text { Koncarevic et al. } \\
\text { 2012; Zhang et al. } \\
2012\end{array}$ \\
\hline Cancer cachexia (mouse) & sActRIIB & $\begin{array}{l}\text { Increased weight gain and muscle } \\
\text { mass; increased survival }\end{array}$ & Zhou et al. 2010 \\
\hline $\begin{array}{l}\text { Duchenne muscular } \\
\text { dystrophy (mouse, } \\
\text { human) }\end{array}$ & sActRIIB; ACE-031 & $\begin{array}{l}\text { Increased muscle mass and } \\
\text { function; phase II clinical trial } \\
\text { terminated }\end{array}$ & $\begin{array}{l}\text { Pistilli et al. 2011; } \\
\text { Wahl } 2013\end{array}$ \\
\hline $\begin{array}{l}\beta \text {-Thalassemia (mouse), } \\
\text { anemia, and } \\
\text { myelodysplastic } \\
\text { syndromes (human) }\end{array}$ & $\begin{array}{l}\text { RAP-536 ACE-536; } \\
\text { ActRIIA-Fc (ACE- } \\
011 \text { [Sotatercept]) }\end{array}$ & $\begin{array}{l}\text { Reduced erythroid hyperplasia; } \\
\text { improved anemia; phase II } \\
\text { clinical trials ongoing }\end{array}$ & $\begin{array}{l}\text { Suragani et al. 2014; } \\
\text { clinical trials.gov }\end{array}$ \\
\hline $\begin{array}{l}\text { Osteoporosis (mouse, } \\
\text { cynomologus monkey) }\end{array}$ & $\begin{array}{l}\text { ActRIIA-Fc (ACE-011 } \\
\quad[\text { Sotatercept }])\end{array}$ & $\begin{array}{l}\text { Increased osteoblast } \\
\text { differentiation, bone mass, and } \\
\text { strength; improved noncortical } \\
\text { bone volume and increased } \\
\text { bone formation; suppressed } \\
\text { bone resorption }\end{array}$ & $\begin{array}{l}\text { Pearsall et al. 2008; } \\
\text { Chantry et al. } \\
\text { 2010; Lotinun } \\
\text { et al. } 2010\end{array}$ \\
\hline $\begin{array}{l}\text { Bone metastasis in breast } \\
\text { cancer (mouse) }\end{array}$ & & $\begin{array}{l}\text { Reduced bone destruction and } \\
\text { bone metastasis }\end{array}$ & \\
\hline Multiple myeloma (mouse) & & $\begin{array}{l}\text { Reduced osteoclastic lesions and } \\
\text { prolonged survival }\end{array}$ & \\
\hline \multicolumn{4}{|l|}{ Modified prodomains } \\
\hline Muscle wasting (mouse) & $\begin{array}{l}\text { Modified activin A } \\
\text { and B prodomains }\end{array}$ & $\begin{array}{l}\text { Specific inhibition of activin A } \\
\text { and B; improved muscle mass }\end{array}$ & Chen et al. 2015 \\
\hline
\end{tabular}


creased brown fat and skeletal muscle mass relative to controls, increased energy expenditure, and increased expression of mitochondrial function and energy expenditure genes; however, there are no effects on white adipose tissue mass (Fournier et al. 2012). The antibody treatment also reduces the activation of Smad3 in brown adipose tissue. In contrast, the soluble receptor, ActRIIB$\mathrm{hFC}$, reverses the effects of diet-induced obesity by increasing energy expenditure and expression of energy expenditure genes in white adipose tissues, including the appearance of brown-like adipocytes (Koncarevic et al. 2012).

Several TGF- $\beta$ family members, that is, GDF-8, GDF-3, GDF-11, and activins A, B, and $A B$, bind ActRIIB with high affinity (Souza et al. 2008; Koncarevic et al. 2012) and are coexpressed in adipose tissues, which challenges our ability to separate direct and indirect effects of each ligand on metabolism in vivo and tissuespecific effects in organs that contribute to nutrient metabolism. However, the results above suggest that ActRIIB signaling is a promising target for the treatment of obesity, diabetes, and conditions in which muscle mass is adversely affected.

\section{Cancer-Induced Cachexia}

Although the morbidity most commonly associated with cancer results from metastasis and its effects, cancer progression also adversely impacts energy metabolism. In advanced cancer, the release of cytokines and other signaling molecules affect the expression of acute-phase proteins and the ubiquitin-dependent proteasome system, culminating in a hypermetabolic "cancer-cachexia" state, with loss of lean and fat body mass. Cachexia is associated with poor clinical outcomes in a variety of settings (Kotler 2000; Acharyya and Guttridge 2007). The first successful use of a soluble ActRIIB antagonist to prevent and reverse cancer cachexia was in four models of tumor-bearing mice, including Inha ${ }^{-/-}$mice. Lean body mass and survival improved despite ongoing tumor growth and elevated proinflammatory cytokine levels. The beneficial effects were observed when soluble ActRIIB treatment was initiated before and after the onset of cachexia (Zhou et al. 2010). Although much attention has been given to ActRIIB, ActRII is also an important contributor to the cancer-cachexia syndrome. In $a^{-/-}$; Acvr2 $2^{-/-}$(ActRII) double mutant mice develop tumors but fail to develop Inha ${ }^{-/-}$-induced cachexia (Coerver et al. 1996), suggesting that both type II activin receptors mediate signals that influence energy homeostasis.

\section{Muscular Dystrophies}

Because reduction of GDF-8 (myostatin) expression dramatically increases muscle mass in several species, and GDF-8 signals through ActRIIB, an ActRIIB-soluble receptor was reasoned to potentially benefit patients with pathologically reduced muscle mass such as in Duchenne muscular dystrophy (DMD). In the $m d x$ mouse model of DMD, 12 weeks of treatment with soluble ActRIIB improved skeletal muscle mass, absolute force production and specific force, with a corresponding decrease in blood creatine kinase (CK) levels, a marker of muscle cell damage. These findings are consistent with an overall improvement in muscle mass, integrity, and function (Pistilli et al. 2011). Accordingly, human clinical trials were initiated in DMD patients, but these were stopped because of off-target effects, which included nosebleeds, gum bleeding, and dilatation of skin vessels (Wahl 2013). These side effects, although mild, underscore the need for agents with high specificity, if therapeutic inhibition strategies are to be successful.

\section{Anemia}

One of the earliest identified functions of activins was the ability to augment EPO-dependent hemoglobin production and enhance proliferation of human bone marrow-derived erythrocyte precursors in vitro ( $\mathrm{Yu}$ et al. 1987). It is therefore counterintuitive that soluble receptor derivatives of the human ActRIIB extracellular domain, ACE-536, or its mouse counterpart, RAP-536, produce rapid and robust increases in erythrocyte numbers under basal conditions, and reduces or prevents anemia in disease mod- 
els. Unlike EPO, which acts at early stages of erythrocyte development, soluble receptors promote maturation of late-stage erythrocyte precursors in vivo. Accordingly, cotreatment with ACE-536 and EPO produces a synergistic erythropoietic response. The apparent paradox regarding activin effects on erythropoiesis is resolved by the binding properties of ACE-536 that were modified to affect the ligand-receptor interface: a single amino acid substitution (L79D), an amino-terminal truncation of four amino acids, and a carboxy-terminal truncation of three amino acids (Suragani et al. 2014). ACE-536 binds activin with low affinity but avidly binds GDF-11 and blocks GDF-11-induced Smad2/3 signaling. GDF-11 inhibits erythroid maturation in mice in vivo and ex vivo, and treatment of mice with RAP-536 reduces Smad 2/3 activation, improves anemia and reduces erythroid hyperplasia (a marker of ineffective erythropoiesis) in a genetic mouse model of myelodysplastic syndrome (MDS) (Suragani et al. 2014). The beneficial effects of RAP-536 are not a result of enhanced activin signaling as a consequence of GDF-11 sequestration, because a neutralizing activin antibody does not reduce the positive effects of RAP-536 on erythropoiesis. ACE-536 also binds myostatin with high affinity and inhibits myostatin signaling, yet RAP-536 does not impact lean body mass in vivo (Suragani et al. 2014). ACE-536 is now in phase 2 clinical trials for treatment of anemia in $\beta$-thalassemia and MDS. Clinical trials for disorders with anemia as a primary or secondary feature are also underway using ACE011 (Sotatercept), an ActRII-soluble receptor that has not been modified at its ligand-binding interface (clinical trials.gov).

\section{Osteopenia}

Diseases that impact bone turnover, such as osteoporosis and cancer metastasis, cause osteopenia and increase fracture risk. Several members of the TGF- $\beta$ family impact the skeleton structurally and functionally, and are implicated in rare inherited bone disorders (reviewed in Chen et al. 2012). Activin A is present at high levels in bone, yet activin signaling in bone metabolism has not been robustly studied. ActRIIA-Fc administration in mice enhances osteoblast differentiation and increases bone mass and strength in normal and ovariectomized, osteoporotic mice (Pearsall et al. 2008). Moreover, in an osteolytic mouse model of multiple myeloma, ActRIIA-Fc triggers osteoblastogenesis, prevents myeloma-induced suppression of bone formation, prevents osteolytic bone lesions, and increases survival. ActRIIA-Fc also prevents bone destruction and inhibits bone metastases in a mouse model of breast cancer (Chantry et al. 2010). In nonhuman primates, human ActRIIA-Fc (ACE-011) improves medullary (noncortical) bone volume by enhancing bone formation and inhibiting bone resorption (Lotinun et al. 2010). These experiments strongly support the rationale for developing soluble activin receptors for the treatment of conditions with osteopenia as a feature, such as age-related osteoporosis, metastatic bone disease, chronic immobility, and menopause. To our knowledge, there are no ongoing clinical trials to investigate these possibilities.

\section{Inflammation}

Activin levels are markedly elevated in humans with life-threatening infections or acute respiratory failure (ARF), and is a poor prognostic indicator in ARF (Michel et al. 2003; de Kretser et al. 2013). In intensive care settings, ARF requires mechanical ventilation for longer than 6 hours, with a 30-day mortality risk of 30\% (Esteban et al. 2002; Linko et al. 2009). Abnormally elevated activin A and B levels correlate significantly with mortality within 1 year of hospitalization, suggesting that activins are biomarkers for patients at highest risk for death (de Kretser et al. 2013). In contrast, activins may confer a protective effect in human newborns. Like ARF patients, premature newborns with life-threatening infections have elevated activin A levels. However, activin A suppresses proinflammatory cytokine production in vitro while enhancing the production of anti-inflammatory cytokines in LPS or phytohemagglutinin-treated peripheral leukocytes from human newborns (Petrakou et al. 2013). These observations 
have led to the idea that modulating activin signaling during these and other inflammatory processes might be clinically beneficial. Consistent with this hypothesis, mice given lethal doses of LPS show improved clinical outcomes when treated with follistatin, and circulating activin levels directly correlate with proinflammatory cytokine production, and inversely with survival (Jones et al. 2007). Also, administered follistatin protects against several inflammatory processes, such as bleomycin-induced lung injury in rats (Aoki et al. 2005), antigen-induced asthma and airway remodeling in mice (Hardy et al. 2006, 2013), early-stage liver fibrosis (Patella et al. 2006), and inflammatory bowel disease (Dohi et al. 2005). This spectrum of benefits in animal models strongly supports potential clinical use. Important considerations, however, are the biphasic complexity of activin contributions to inflammatory processes and potential off-target effects of systemic follistatin administration. To our knowledge, no ongoing human clinical trials target activin-associated inflammation.

\section{FUTURE DIRECTIONS: INHIBITION OF ACTIVIN SIGNALING - THERAPEUTIC POTENTIAL AND POSSIBLE PITFALLS}

Although much attention has been given to GDF-8 as the primary ligand target for beneficial effects of ActRIIB inhibition on body composition, metabolism, and energy expenditure, other ligands and receptors, notably the activins and ActRII, may contribute substantially to these processes (Coerver et al. 1996; Lee and McPherron 2001; Lee et al. 2005; Souza et al. 2008). Moreover, myostatin-deficient mice treated with soluble ActRIIB show a further increase in muscle mass, suggesting that other ligands contribute (Lee et al. 2005), and activins have recently been implicated as negative regulators of muscle mass in vivo (Chen et al. 2015). Therefore, soluble receptors and other "ligand traps" will ultimately impact the functions of all ligand partners, particularly those that bind with high affinity. To be most useful clinically, more selective approaches are needed, such as altering the binding characteristics of the traps through mutagenesis, as in ACE-536, or using ligand-selective modified prodomains. These agents will not only be useful clinically, but also provide tools to dissect the milieu of factors that affect biological outcomes in vivo. Restricting therapeutic inhibition strategies to a single ligand or a selected combination of ligands will help to achieve the most desirable clinical outcomes while minimizing undesirable side effects. It will be interesting to determine whether targeting specific ligands has beneficial effects on body composition, metabolism, and other processes in which activins participate. Efforts to develop such agents are underway, with evidence that selective inhibitors reproduce some characteristics of the soluble receptors in vivo (Schneyer et al. 2008; Datta-Mannan et al. 2013; Suragani et al. 2014; Chen et al. 2015). Based on the early successes of several TGF- $\beta$ inhibitors, additional strategies for attenuating activin signaling should be explored, which include blocking the expression of specific ligands or the translation of their mRNAs using antisense molecules, producing antibodies that target ligands, receptors, and associated proteins, blocking the conversion from latent to active ligand, identifying and refining ligand-competitive peptide inhibitors, blocking receptor kinases using small molecules, or blocking transcription effects of Smad complexes.

An important challenge facing inhibition of specific ligands, particularly activins that are widely expressed, is that off-target effects because of suppression of activin signaling in other tissues might limit the potential for clinical use. However, this possibility exists for any new therapeutic agent, and the clinical risk to benefit ratio must always be carefully considered. We are encouraged by the progress of several clinical trials that successfully target TGF- $\beta$ signaling to improve outcomes for a variety of cancers and fibrotic diseases (reviewed in Akhurst and Hata 2012).

\section{REFERENCES}

Acharyya S, Guttridge DC. 2007. Cancer cachexia signaling pathways continue to emerge yet much still points to the proteasome. Clin Cancer Res 13: 1356-1361. 
Ageta H, Murayama A, Migishima R, Kida S, Tsuchida K, Yokoyama M, Inokuchi K. 2008. Activin in the brain modulates anxiety-related behavior and adult neurogenesis. PLoS ONE 3: e1869.

Ageta H, Ikegami S, Miura M, Masuda M, Migishima R, Hino T, Takashima N, Murayama A, Sugino H, Setou $\mathrm{M}$, et al. 2010. Activin plays a key role in the maintenance of long-term memory and late-LTP. Learn Mem 17: $176-$ 185.

Akhurst RJ, Hata A. 2012. Targeting the TGF $\beta$ signalling pathway in disease. Nat Rev Drug Discov 11: 790-811.

Akpan I, Goncalves MD, Dhir R, Yin X, Pistilli EE, Bogdanovich S, Khurana TS, Ucran J, Lachey J, Ahima RS. 2009. The effects of a soluble activin type IIB receptor on obesity and insulin sensitivity. Int J Obes (Lond) 33: 1265-1273.

Albano RM, Smith JC. 1994. Follistatin expression in ES and F9 cells and in preimplantation mouse embryos. Int J Dev Biol 38: 543-547.

Allen DL, Cleary AS, Speaker KJ, Lindsay SF, Uyenishi J, Reed JM, Madden MC, Mehan RS. 2008. Myostatin, activin receptor IIb, and follistatin-like-3 gene expression are altered in adipose tissue and skeletal muscle of obese mice. Am J Physiol Endocrinol Metab 294: E918-E927.

Allendorph GP, Vale WW, Choe S. 2006. Structure of the ternary signaling complex of a TGF- $\beta$ superfamily member. Proc Natl Acad Sci 103: 7643-7648.

Allendorph GP, Isaacs MJ, Kawakami Y, Izpisua Belmonte JC, Choe S. 2007. BMP-3 and BMP-6 structures illuminate the nature of binding specificity with receptors. Biochemistry 46: 12238-12247.

Andersson O, Korach-Andre M, Reissmann E, Ibanez CF, Bertolino P. 2008. Growth/differentiation factor 3 signals through ALK7 and regulates accumulation of adipose tissue and diet-induced obesity. Proc Natl Acad Sci 05: $7252-7256$.

Antenos M, Stemler M, Boime I, Woodruff TK. 2007. Nlinked oligosaccharides direct the differential assembly and secretion of inhibin $\alpha$ - and $\beta A$-subunit dimers. Mol Endocrinol 21: 1670-1684.

Antenos M, Zhu J, Jetly NM, Woodruff TK. 2008. An activin/furin regulatory loop modulates the processing and secretion of inhibin $\alpha$ - and $\beta B$-subunit dimers in pituitary gonadotrope cells. J Biol Chem 283: 33059-33068.

Antenos M, Lei L, Xu M, Malipatil A, Kiesewetter S, Woodruff TK. 2011. Role of PCSK5 expression in mouse ovarian follicle development: Identification of the inhibin $\alpha$ - and $\beta$-subunits as candidate substrates. PLoS ONE 6: e17348.

Antsiferova M, Werner S. 2012. The bright and the dark sides of activin in wound healing and cancer. J Cell Sci 125: 3929-3937.

Antsiferova M, Klatte JE, Bodo E, Paus R, Jorcano JL, Matzuk MM, Werner S, Kogel H. 2009. Keratinocyte-derived follistatin regulates epidermal homeostasis and wound repair. Lab Invest 89: 131-141.

Antsiferova M, Huber M, Meyer M, Piwko-Czuchra A, Ramadan T, MacLeod AS, Havran WL, Dummer R, Hohl D, Werner S. 2011. Activin enhances skin tumourigenesis and malignant progression by inducing a protumourigenic immune cell response. Nat Commun 2: 576.
Aoki F, Kurabayashi M, Hasegawa Y, Kojima I. 2005. Attenuation of bleomycin-induced pulmonary fibrosis by follistatin. Am J Respir Crit Care Med 172: 713-720.

Aono T, Sugino H, Vale WW, eds. 1997. Inhibin, activin and follistatin regulatory functions in system and cell biology. Springer, New York.

Arai KY, Ohshima K, Watanabe G, Arai K, Uehara K, Taya K. 2002. Dynamics of messenger RNAs encoding inhibin/ activin subunits and follistatin in the ovary during the rat estrous cycle. Biol Reprod 66: 1119-1126.

Archambeault DR, Yao HH. 2010. Activin A, a product of fetal Leydig cells, is a unique paracrine regulator of Sertoli cell proliferation and fetal testis cord expansion. Proc Nat Acad Sci 107: 10526-10531.

Ashcroft GS, Yang X, Glick AB, Weinstein M, Letterio JL, Mizel DE, Anzano M, Greenwell-Wild T, Wahl SM, Deng C, et al. 1999. Mice lacking Smad3 show accelerated wound healing and an impaired local inflammatory response. Nat Cell Biol 1: 260-266.

Attisano L, Wrana JL, Cheifetz S, Massagué J. 1992. Novel activin receptors: Distinct genes and alternative mRNA splicing generate a repertoire of serine/threonine kinase receptors. Cell 68: 97-108.

Attisano L, Wrana JL, Montalvo E, Massagué J. 1996. Activation of signalling by the activin receptor complex. Mol Cell Biol 16: 1066-1073.

Bamberger C, Scharer A, Antsiferova M, Tychsen B, Pankow S, Muller M, Rulicke T, Paus R, Werner S. 2005. Activin controls skin morphogenesis and wound repair predominantly via stromal cells and in a concentration-dependent manner via keratinocytes. Am J Pathol 167: $733-$ 747.

Bernard DJ, Lee KB, Santos MM. 2006. Activin B can signal through both ALK4 and ALK7 in gonadotrope cells. Reprod Biol Endocrinol 4: 52.

Bertolino P, Holmberg R, Reissmann E, Andersson O, Berggren PO, Ibanez CF. 2008. Activin B receptor ALK7 is a negative regulator of pancreatic $\beta$-cell function. Proc Natl Acad Sci 105: 7246-7251.

Besecke LM, Guendner MJ, Sluss PA, Polak AG, Woodruff TK, Jameson JL, Bauer-Dantoin AC, Weiss J. 1997. Pituitary follistatin regulates activin-mediated production of follicle-stimulating hormone during the rat estrous cycle. Endocrinology 138: 2841-2848.

Besson-Fournier C, Latour C, Kautz L, Bertrand J, Ganz T, Roth MP, Coppin H. 2012. Induction of activin B by inflammatory stimuli up-regulates expression of the iron-regulatory peptide hepcidin through Smad1/5/8 signaling. Blood 120: 431-439.

Bilezikjian LM, Blount AL, Leal AM, Donaldson CJ, Fischer WH, Vale WW. 2004. Autocrine/paracrine regulation of pituitary function by activin, inhibin and follistatin. $\mathrm{Mol}$ Cell Endocrinol 225: 29-36.

Bloise E, Couto HL, Massai L, Ciarmela P, Mencarelli M, Borges LE, Muscettola M, Grasso G, Amaral VF, Cassali GD, et al. 2009. Differential expression of follistatin and FLRG in human breast proliferative disorders. BMC Cancer 9: 320 .

Bonomi L, Brown M, Ungerleider N, Muse M, Matzuk MM, Schneyer A. 2012. Activin B regulates islet composition and islet mass but not whole body glucose homeostasis or 
insulin sensitivity. Am J Physiol Endocrinol Metab 303: E587-596.

Bristol-Gould SK, Kreeger PK, Selkirk CG, Kilen SM, Cook RW, Kipp JL, Shea LD, Mayo KE, Woodruff TK. 2006. Postnatal regulation of germ cells by activin: The establishment of the initial follicle pool. Dev Biol 298: 132148.

Brown CW, Houston-Hawkins DE, Woodruff TK, Matzuk MM. 2000. Insertion of Inhbb into the Inhba locus rescues the Inhba-null phenotype and reveals new activin functions. Nat Genet 25: 453-457.

Brown CW, Li L, Houston-Hawkins DE, Matzuk MM. 2003. Activins are critical modulators of growth and survival. Mol Endocrinol 17: 2404-2417.

Brown ML, Kimura F, Bonomi LM, Ungerleider NA, Schneyer AL. 2011. Differential synthesis and action of TGF $\beta$ superfamily ligands in mouse and rat islets. Islets 3 : 367-375.

Burger LL, Dalkin AC, Aylor KW, Haisenleder DJ, Marshall JC. 2002. GnRH pulse frequency modulation of gonadotropin subunit gene transcription in normal gonadotropes-Assessment by primary transcript assay provides evidence for roles of GnRH and follistatin. Endocrinology 143: 3243-3249.

Burger LL, Haisenleder DJ, Aylor KW, Dalkin AC, Prendergast KA, Marshall JC. 2003. Regulation of luteinizing hormone- $\beta$ and follicle-stimulating hormone (FSH)- $\beta$ gene transcription by androgens: Testosterone directly stimulates FSH- $\beta$ transcription independent from its role on follistatin gene expression. Endocrinology 145: 71-78.

Burns KH, Agno JE, Chen L, Haupt B, Ogbonna SC, Korach KS, Matzuk MM. 2003a. Sexually dimorphic roles of steroid hormone receptor signaling in gonadal tumorigenesis. Mol Endocrinol 17: 2039-2052.

Burns KH, Agno JE, Sicinski P, Matzuk MM. 2003b. Cyclin D2 and p27 are tissue-specific regulators of tumorigenesis in inhibin $\alpha$ knockout mice. Mol Endocrinol 17: 2053 2069.

Buzzard JJ, Farnworth PG, De Kretser DM, O'Connor AE, Wreford NG, Morrison JR. 2003. Proliferative phase sertoli cells display a developmentally regulated response to activin in vitro. Endocrinology 144: 474-483.

Buzzard JJ, Loveland KL, O’Bryan MK, O’Connor AE, Bakker M, Hayashi T, Wreford NG, Morrison JR, de Kretser DM. 2004. Changes in circulating and testicular levels of inhibin A and B and activin A during postnatal development in the rat. Endocrinology 145: 3532-3541.

Cameron VA, Nishimura E, Mathews LS, Lewis KA, Sawchenko PE, Vale WW. 1994. Hybridization histochemical localization of activin receptor subtypes in rat brain, pituitary, ovary, and testis. Endocrinology 134: 799-808.

Campbell BK, Baird DT. 2001. Inhibin A is a follicle stimulating hormone-responsive marker of granulosa cell differentiation, which has both autocrine and paracrine actions in sheep. J Endocrinol 169: 333-345.

Cancello R, Henegar C, Viguerie N, Taleb S, Poitou C, Rouault C, Coupaye M, Pelloux V, Hugol D, Bouillot J-L, et al. 2005. Reduction of macrophage infiltration and chemoattractant gene expression changes in white adipose tissue of morbidly obese subjects after surgery-induced weight loss. Diabetes 54: 2277-2286.
Cárcamo J, Weis FM, Ventura F, Wieser R, Wrana JL, Attisano L, Massagué J. 1994. Type I receptors specify growth-inhibitory and transcriptional responses to transforming growth factor $\beta$ and activin. Mol Cell Biol 14: 3810-3821.

Centrella M, McCarthy TL, Canalis E. 1991. Activin-A binding and biochemical effects in osteoblast-enriched cultures from fetal-rat parietal bone. Mol Cell Biol 11: 250-258.

Chabicovsky M, Herkner K, Rossmanith W. 2003. Overexpression of activin $\beta C$ or activin $\beta E$ in the mouse liver inhibits regenerative deoxyribonucleic acid synthesis of hepatic cells. Endocrinology 144: 3497-3504.

Chang KP, Kao HK, Liang Y, Cheng MH, Chang YL, Liu SC, Lin YC, Ko TY, Lee YS, Tsai CL, et al. 2010. Overexpression of activin A in oral squamous cell carcinoma: Association with poor prognosis and tumor progression. Ann Surg Oncol 17: 1945-1956.

Chantry AD, Heath D, Mulivor AW, Pearsall S, Baud'huin M, Coulton L, Evans H, Abdul N, Werner ED, Bouxsein ML, et al. 2010. Inhibiting activin-A signaling stimulates bone formation and prevents cancer-induced bone destruction in vivo. J Bone Miner Res 25: 2633-2646.

Chen W, Woodruff TK, Mayo KE. 2000. Activin A-induced HepG2 liver cell apoptosis: Involvement of activin receptors and smad proteins. Endocrinology 141: 1263-1272.

Chen C, Ware SM, Sato A, Houston-Hawkins DE, Habas R, Matzuk MM, Shen MM, Brown CW. 2006. The Vg1-related protein Gdf3 acts in a Nodal signaling pathway in the pre-gastrulation mouse embryo. Development 133: 319-329.

Chen J, Bush JO, Ovitt CE, Lan Y, Jiang R. 2007. The TGF- $\beta$ pseudoreceptor gene Bambi is dispensable for mouse embryonic development and postnatal survival. Genesis 45: $482-486$.

Chen G, Deng C, Li YP. 2012. TGF- $\beta$ and BMP signaling in osteoblast differentiation and bone formation. Int J Biol Sci 8: $272-288$.

Chen JL, Walton KL, Al-Musawi SL, Kelly EK, Qian H, La M, Lu L, Lovrecz G, Ziemann M, Lazarus R, et al. 2015. Development of novel activin-targeted therapeutics. Mol Ther 23: 434-444.

Cheng SK, Olale F, Bennett JT, Brivanlou AH, Schier AF. 2003. EGF-CFC proteins are essential coreceptors for the TGF- $\beta$ signals Vg1 and GDF1. Genes Dev 17: 31-36.

Cho BN, McMullen ML, Pei L, Yates CJ, Mayo KE. 2001. Reproductive deficiencies in transgenic mice expressing the rat inhibin $\alpha$-subunit gene. Endocrinology 142: 49945004.

Choy L, Skillington J, Derynck R. 2000. Roles of autocrine TGF- $\beta$ receptor and Smad signaling in adipocyte differentiation. J Cell Biol 149: 667-682.

Ciarmela P, Florio P, Toti P, Franchini A, Maguer-Satta V, Ginanneschi C, Ottaviani E, Petraglia F. 2003. Human placenta and fetal membranes express follistatin-related gene mRNA and protein. J Endocrinol Invest 26: 641-645.

Cipriano SC, Chen L, Kumar TR, Matzuk MM. 2000. Follistatin is a modulator of gonadal tumor progression and the activin-induced wasting syndrome in inhibin-deficient mice. Endocrinology 141: 2319-2327. 
Cipriano SC, Chen L, Burns KH, Koff A, Matzuk MM. 2001. Inhibin and p27 interact to regulate gonadal tumorigenesis. Mol Endocrinol 15: 985-996.

Clifton RJ, O’Donnell L, Robertson DM. 2002. Pachytene spermatocytes in co-culture inhibit rat Sertoli cell synthesis of inhibin $\beta B$-subunit and inhibin $B$ but not the inhibin $\alpha$-subunit. J Endocrinol 172: 565-574.

Cocolakis E, Lemay S, Ali S, Lebrun JJ. 2001. The p38 MAPK pathway is required for cell growth inhibition of human breast cancer cells in response to activin. J Biol Chem 276: 18430-18436.

Coerver KA, Woodruff TK, Finegold MJ, Mather J, Bradley A, Matzuk MM. 1996. Activin signaling through activin receptor type II causes the cachexia-like symptoms in inhibin-deficient mice. Mol Endocrinol 10: 534-543.

Corrigan AZ, Bilezikjian LM, Carroll RS, Bald LN, Schmelzer CH, Fendly BM, Mason AJ, Chin WW, Schwall RH, Vale W. 1991. Evidence for an autocrine role of activin B within rat anterior pituitary cultures. Endocrinology 128: $1682-1684$.

Coss D, Thackray VG, Deng CX, Mellon PL. 2005. Activin regulates luteinizing hormone $\beta$-subunit gene expression through Smad-binding and homeobox elements. Mol Endocrinol 19: 2610-2623.

Das P, Inoue H, Baker JC, Beppu H, Kawabata M, Harland RM, Miyazono K, Padgett RW. 1999. Drosophila dSmad2 and Atr-I transmit activin/TGF $\beta$ signals. Genes Cells 4: $123-134$.

Datta-Mannan A, Yaden B, Krishnan V, Jones BE, Croy JE. 2013. An engineered human follistatin variant: Insights into the pharmacokinetic and pharmocodynamic relationships of a novel molecule with broad therapeutic potential. J Pharmacol Exp Ther 344: 616-623.

Davis AA, Matzuk MM, Reh TA. 2000. Activin A promotes progenitor differentiation into photoreceptors in rodent retina. Mol Cell Neurosci 15: 11-21.

De Bleser PJ, Niki T, Xu G, Rogiers V, Geerts A. 1997. Localization and cellular sources of activins in normal and fibrotic rat liver. Hepatology 26: 905-912.

Degen WG, Weterman MA, van Groningen JJ, Cornelissen IM, Lemmers JP, Agterbos MA, Geurts van Kessel A, Swart GW, Bloemers HP. 1996. Expression of $n m a$, a novel gene, inversely correlates with the metastatic potential of human melanoma cell lines and xenografts. Int J Cancer 65: $460-465$.

de Guise C, Lacerte A, Rafiei S, Reynaud R, Roy M, Brue T, Lebrun JJ. 2006. Activin inhibits the human Pit-1 gene promoter through the $\mathrm{p} 38$ kinase pathway in a Smadindependent manner. Endocrinology 147: 4351-4362.

De Jong FH, Sharpe RM. 1976. Evidence for inhibin-like activity in bovine follicular fluid. Nature 263: 71-72.

de Kretser DM, Bensley JG, Pettila V, Linko R, Hedger MP, Hayward S, Allan CA, McLachlan RI, Ludlow H, Phillips DJ. 2013. Serum activin A and B levels predict outcome in patients with acute respiratory failure: A prospective cohort study. Crit Care 17: R263.

Del Re E, Sidis Y, Fabrizio DA, Lin HY, Schneyer A. 2004. Reconstitution and analysis of soluble inhibin and activin receptor complexes in a cell-free system. J Biol Chem 279: $53126-53135$
Derynck R, Gelbart WM, Harland RM, Heldin CH, Kern SE, Massagué J, Melton DA, Mlodzik M, Padgett RW, Roberts AB, et al. 1996. Nomenclature: vertebrate mediators of TGF $\beta$ family signals. Cell 87: 173 .

Di Simone N, Lanzone A, Petraglia F, Ronsisvalle E, Caruso A, Mancuso S. 1994. Effect of activin-A on progesterone synthesis in human luteal cells. Fertil Steril 62: 11571161.

Dohi T, Ejima C, Kato R, Kawamura YI, Kawashima R, Mizutani N, Tabuchi Y, Kojima I. 2005. Therapeutic potential of follistatin for colonic inflammation in mice. Gastroenterology 128: 411-423.

Dong J, Albertini DF, Nishimori K, Kumar TR, Lu N, Matzuk MM. 1996. Growth differentiation factor-9 is required during early ovarian folliculogenesis. Nature 383: $531-535$.

Drummond AE, Le MT, Ethier JF, Dyson M, Findlay JK. 2002. Expression and localization of activin receptors, Smads, and betaglycan to the postnatal rat ovary. Endocrinology 143: 1423-1433.

Dutta DJ, Zameer A, Mariani JN, Zhang J, Asp L, Huynh J, Mahase S, Laitman BM, Argaw AT, Mitiku N, et al. 2014. Combinatorial actions of TGF $\beta$ and activin ligands promote oligodendrocyte development and CNS myelination. Development 141: 2414-2428.

Dyson S, Gurdon JB. 1998. The interpretation of position in a morphogen gradient as revealed by occupancy of activin receptors. Cell 93: 557-568.

Eijken M, Swagemakers S, Koedam M, Steenbergen C, Derkx P, Uitterlinden AG, van der Spek PJ, Visser JA, de Jong FH, Pols HA, et al. 2007. The activin A-follistatin system: Potent regulator of human extracellular matrix mineralization. FASEB J 21: 2949-2960.

Engström G, Hedblad B, Stavenow L, Lind P, Janzon L, Lindgärde F. 2003. Inflammation-sensitive plasma proteins are associated with future weight gain. Diabetes 52: 2097-2101.

Esch FS, Shimasaki S, Mercado M, Cooksey K, Ling N, Ying S, Ueno N, Guillemin R. 1987. Structural characterization of follistatin: A novel follicle-stimulating hormone release-inhibiting polypeptide from the gonad. Mol Endocrinol 1: 849-855.

Escribese MM, Sierra-Filardi E, Nieto C, Samaniego R, Sanchez-Torres C, Matsuyama T, Calderon-Gomez E, Vega MA, Salas A, Sanchez-Mateos P, et al. 2012. The prolyl hydroxylase PHD3 identifies proinflammatory macrophages and its expression is regulated by activin A. $J$ Immunol 189: 1946-1954.

Esquela AF, Zimmers TA, Koniaris LG, Sitzmann JV, Lee SJ. 1997. Transient down-regulation of inhibin- $\beta C$ expression following partial hepatectomy. Biochem Biophys Res Commun 235: 553-556.

Esteban A, Anzueto A, Frutos F, Alia I, Brochard L, Stewart TE, Benito S, Epstein SK, Apezteguia C, Nightingale P, et al. 2002. Characteristics and outcomes in adult patients receiving mechanical ventilation: A 28-day international study. JAMA 287: 345-355.

Eto Y, Tsuji T, Takezawa M, Takano S, Yokogawa Y, Shibai H. 1987. Purification and characterization of erythroid differentiation factor (EDF) isolated from human leukemia cell line THP-1. Biochem Biophys Res Commun 142: 1095-1103. 
Fang J, Yin W, Smiley E, Wang SQ, Bonadio J. 1996. Molecular cloning of the mouse activin $\beta E$ subunit gene. Biochem Biophys Res Commun 228: 669-674.

Fang J, Wang SQ, Smiley E, Bonadio J. 1997. Genes coding for mouse activin $\beta C$ and $\beta E$ are closely linked and exhibit a liver-specific expression pattern in adult tissues. Biochem Biophys Res Commun 231: 655-661.

Feijen A, Goumans MJ, van den Eijnden-van Raaij AJ. 1994 Expression of activin subunits, activin receptors and follistatin in postimplantation mouse embryos suggests specific developmental functions for different activins. Development 120: $3621-3637$.

Fernandez-Vazquez G, Kaiser UB, Albarracin CT, Chin WW. 1996. Transcriptional activation of the gonadotropin-releasing hormone receptor gene by activin A. Mol Endocrinol 10: 356-366.

Feuerer M, Herrero L, Cipolletta D, Naaz A, Wong J, Nayer A, Lee J, Goldfine AB, Benoist C, Shoelson S, et al. 2009. Lean, but not obese, fat is enriched for a unique population of regulatory $\mathrm{T}$ cells that affect metabolic parameters. Nat Med 15: 930-939.

Florio P, Ciarmela P, Toti P, Maguer-Satta V, Rimokh R, Buonocore G, Rossi M, Gioffre W, Petraglia F. 2004. Human endometrium and decidua express follistatin-related gene (FLRG) mRNA and peptide. Mol Cell Endocrinol 218: $129-135$.

Fournier B, Murray B, Gutzwiller S, Marcaletti S, Marcellin D, Bergling S, Brachat S, Persohn E, Pierrel E, Bombard F, et al. 2012. Blockade of the activin receptor IIb activates functional brown adipogenesis and thermogenesis by inducing mitochondrial oxidative metabolism. Mol Cell Biol 32: 2871-2879.

Fuller K, Bayley KE, Chambers TJ. 2000. Activin A is an essential cofactor for osteoclast induction. Biochem Biophys Res Commun 268: 2-7.

Gaddy-Kurten D, Coker JK, Abe E, Jilka RL, Manolagas SC 2002. Inhibin suppresses and activin stimulates osteoblastogenesis and osteoclastogenesis in murine bone marrow cultures. Endocrinology 143: 74-83.

Gaedeke J, Boehler T, Budde K, Neumayer HH, Peters H. 2005. Glomerular activin A overexpression is linked to fibrosis in anti-Thyl glomerulonephritis. Nephrol Dial Transplant 20: 319-328.

Gallinelli A, Gallo R, Genazzani AD, Matteo ML, Caruso A, Woodruff TK, Petraglia F. 1996. Episodic secretion of activin A in pregnant women. Eur J Endocrinol 135: 340-344.

Ge J, Wang Y, Feng Y, Liu H, Cui X, Chen F, Tai G, Liu Z 2009. Direct effects of activin A on the activation of mouse macrophage RAW264.7 cells. Cell Mol Immunol 6: $129-133$.

Ghosh AC, O'Connor MB. 2014. Systemic Activin signaling independently regulates sugar homeostasis, cellular metabolism, and $\mathrm{pH}$ balance in Drosophila melanogaster. Proc Natl Acad Sci 111: 5729-5734.

Glister C, Kemp CF, Knight PG. 2004. Bone morphogenetic protein (BMP) ligands and receptors in bovine ovarian follicle cells: Actions of BMP-4, -6 and -7 on granulosa cells and differential modulation of Smad-1 phosphorylation by follistatin. Reproduction 127: 239-254.

Gold EJ, O'Bryan MK, Mellor SL, Cranfield M, Risbridger GP, Groome NP, Fleming JS. 2004. Cell-specific expres- sion of $\beta C$-activin in the rat reproductive tract, adrenal and liver. Mol Cell Endocrinol 222: 61-69.

Gold EJ, Zhang X, Wheatley AM, Mellor SL, Cranfield M, Risbridger GP, Groome NP, Fleming JS. 2005. $\beta A$ - and $\beta C$-activin, follistatin, activin receptor mRNA and $\beta C$ activin peptide expression during rat liver regeneration. $J$ Mol Endocrinol 34: 505-515.

Gold E, Jetly N, O’Bryan MK, Meachem S, Srinivasan D, Behuria S, Sanchez-Partida LG, Woodruff T, Hedwards S, Wang H, et al. 2009. Activin C antagonizes activin A in vitro and overexpression leads to pathologies in vivo. $A m$ J Pathol 174: 184-195.

Gold E, Marino FE, Harrison C, Makanji Y, Risbridger G. 2013 . Activin- $\beta C$ reduces reproductive tumour progression and abolishes cancer-associated cachexia in inhibindeficient mice. J Pathol 229: 599-607.

Gray AM, Mason AJ. 1990. Requirement for activin A and transforming growth factor- $\beta 1$ pro-regions in homodimer assembly. Science 247: 1328-1330.

Gray PC, Greenwald J, Blount AL, Kunitake KS, Donaldson CJ, Choe S, Vale W. 2000. Identification of a binding site on the type II activin receptor for activin and inhibin. J Biol Chem 275: 3206-3212.

Gray PC, Harrison CA, Vale W. 2003. Cripto forms a complex with activin and type II activin receptors and can block activin signaling. Proc Natl Acad Sci 100: $5193-$ 5198.

Gray PC, Shani G, Aung K, Kelber J, Vale W. 2006. Cripto binds transforming growth factor $\beta$ (TGF- $\beta$ ) and inhibits TGF- $\beta$ signaling. Mol Cell Biol 26: 9268-9278.

Green JB, Smith JC. 1990. Graded changes in dose of a Xenopus activin A homologue elicit stepwise transitions in embryonic cell fate. Nature 347: 391-394.

Greenwald J, Fischer WH, Vale WW, Choe S. 1999. Threefinger toxin fold for the extracellular ligand-binding domain of the type II activin receptor serine kinase. Nat Struct Biol 6: 18-22.

Greenwald J, Groppe J, Gray P, Wiater E, Kwiatkowski W, Vale W, Choe S. 2003. The BMP7/ActRII extracellular domain complex provides new insights into the cooperative nature of receptor assembly. Mol Cell 11: 605-617.

Greenwald J, Vega ME, Allendorph GP, Fischer WH, Vale W, Choe S. 2004. A flexible activin explains the membranedependent cooperative assembly of TGF- $\beta$ family receptors. Mol Cell 15: 485-489.

Groome NP, Illingworth PJ, O'Brien M, Pai R, Rodger FE, Mather JP, McNeilly AS. 1996. Measurement of dimeric inhibin B throughout the human menstrual cycle. J Clin Endocrinol Metab 81: 1401-1405.

Grootenhuis AJ, Timmerman MA, Hordijk PL, de Jong FH. 1990. Inhibin in immature rat Sertoli cell conditioned medium: A $32 \mathrm{kDa} \alpha \beta-\mathrm{B}$ dimer. Mol Cell Endocrinol 70: $109-116$.

Grotewold L, Plum M, Dildrop R, Peters T, Ruther U. 2001. Bambi is coexpressed with Bmp-4 during mouse embryogenesis. Mech Dev 100: 327-330.

Gu Z, Nomura M, Simpson BB, Lei H, Feijen A, van den Eijnden-van Raaij J, Donahoe PK, Li E. 1998. The type I activin receptor ActRIB is required for egg cylinder organization and gastrulation in the mouse. Genes Dev 12: $844-857$. 
Guo Q, Kumar TR, Woodruff T, Hadsell LA, DeMayo FJ, Matzuk MM. 1998. Overexpression of mouse follistatin causes reproductive defects in transgenic mice. $\mathrm{Mol} \mathrm{En-}$ docrinol 12: 96-106.

Gurdon JB, Bourillot PY. 2001. Morphogen gradient interpretation. Nature 413: 797-803.

Gurdon JB, Harger P, Mitchell A, Lemaire P. 1994. Activin signalling and response to a morphogen gradient. Nature 371: 487-492.

Hagemann AI, Xu X, Nentwich O, Hyvonen M, Smith JC. 2009. Rab5-mediated endocytosis of activin is not required for gene activation or long-range signalling in Xenopus. Development 136: 2803-2813.

Hancock AD, Robertson DM, de Kretser DM. 1992. Inhibin and inhibin $\alpha$-chain precursors are produced by immature rat Sertoli cells in culture. Biol Reprod 46: 155-161.

Hardy CL, O'Connor AE, Yao J, Sebire K, de Kretser DM, Rolland JM, Anderson GP, Phillips DJ, O’Hehir RE. 2006. Follistatin is a candidate endogenous negative regulator of activin A in experimental allergic asthma. Clin Exp Allergy 36: 941-950.

Hardy CL, Nguyen HA, Mohamud R, Yao J, Oh DY, Plebanski M, Loveland KL, Harrison CA, Rolland JM, O'Hehir RE. 2013. The activin A antagonist follistatin inhibits asthmatic airway remodelling. Thorax 68: 9-18.

Hardy CL, King SJ, Mifsud NA, Hedger MP, Phillips DJ, Mackay F, de Kretser DM, Wilson JW, Rolland JM, O'Hehir RE. 2015. The activin A antagonist follistatin inhibits cystic fibrosis-like lung inflammation and pathology. Immunol Cell Biol 93: 567-574.

Harrington AE, Morris-Triggs SA, Ruotolo BT, Robinson CV, Ohnuma S, Hyvonen M. 2006. Structural basis for the inhibition of activin signalling by follistatin. EMBO J 25: 1035-1045.

Harrison CA, Gray PC, Koerber SC, Fischer W, Vale W. 2003. Identification of a functional binding site for activin on the type I receptor ALK4. J Biol Chem 278: 21129-21135.

Harrison CA, Chan KL, Robertson DM. 2006. Activin-A binds follistatin and type II receptors through overlapping binding sites: Generation of mutants with isolated binding activities. Endocrinology 147: 2744-2753.

Hashimoto O, Nakamura T, Shoji H, Shimasaki S, Hayashi Y, Sugino H. 1997. A novel role of follistatin, an activinbinding protein, in the inhibition of activin action in rat pituitary cells. Endocytotic degradation of activin and its acceleration by follistatin associated with cell-surface heparan sulfate. J Biol Chem 272: 13835-13842.

Hashimoto O, Tsuchida K, Ushiro Y, Hosoi Y, Hoshi N, Sugino H, Hasegawa Y. 2002. cDNA cloning and expression of human activin $\beta \mathrm{E}$ subunit. Mol Cell Endocrinol 194: $117-122$.

Hashimoto O, Ushiro Y, Sekiyama K, Yamaguchi O, Yoshioka K, Mutoh K, Hasegawa Y. 2006. Impaired growth of pancreatic exocrine cells in transgenic mice expressing human activin $\beta E$ subunit. Biochem Biophys Res Commun 341: 416-424.

Hay DC, Fletcher J, Payne C, Terrace JD, Gallagher RC, Snoeys J, Black JR, Wojtacha D, Samuel K, Hannoun Z, et al. 2008. Highly efficient differentiation of hESCs to functional hepatic endoderm requires Activin A and Wnt3a signaling. Proc Natl Acad Sci 105: 12301-12306.
Hayes FJ, Pitteloud N, DeCruz S, Crowley WF Jr, Boepple PA. 2001. Importance of inhibin B in the regulation of FSH secretion in the human male. J Clin Endocrinol Metab 86: 5541-5546.

Hayette S, Gadoux M, Martel S, Bertrand S, Tigaud I, Magaud JP, Rimokh R. 1998. FLRG (follistatin-related gene), a new target of chromosomal rearrangement in malignant blood disorders. Oncogene 16: 2949-2954.

Heldin CH, Miyazono K, ten Dijke P. 1997. TGF- $\beta$ signalling from cell membrane to nucleus through SMAD proteins. Nature 390: 465-471.

Hill CS. 2009. Nucleocytoplasmic shuttling of Smad proteins. Cell Res 19: 36-46.

Hill JJ, Davies MV, Pearson AA, Wang JH, Hewick RM, Wolfman NM, Qiu Y. 2002. The myostatin propeptide and the follistatin-related gene are inhibitory binding proteins of myostatin in normal serum. $J$ Biol Chem 277: 40735-40741.

Hillier SG, Miro F. 1993. Inhibin, activin, and follistatin. Potential roles in ovarian physiology. Ann NY Acad Sci 687: 29-38.

Hillier SG, Wickings EJ, Illingworth PI, Yong EL, Reichert LE Jr, Baird DT, McNeilly AS. 1991a. Control of immunoactive inhibin production by human granulosa cells. Clin Endocrinol (Oxf) 35: 71-78.

Hillier SG, Yong EL, Illingworth PJ, Baird DT, Schwall RH, Mason AJ. 1991b. Effect of recombinant inhibin on androgen synthesis in cultured human thecal cells. Mol Cell Endocrinol 75: R1-6.

Hirai S, Yamanaka M, Kawachi H, Matsui T, Yano H. 2005. Activin A inhibits differentiation of 3T3-L1 preadipocyte. Mol Cell Endocrinol 232: 21-26.

Hoggard N, Cruickshank M, Moar KM, Barrett P, Bashir S, Miller JD. 2009. Inhibin $\beta B$ expression in murine adipose tissue and its regulation by leptin, insulin and dexamethasone. J Mol Endocrinol 43: 171-177.

Hotamisligil GS, Shargill NS, Spiegelman BM. 1993. Adipose expression of tumor necrosis factor- $\alpha$ : Direct role in obesity-linked insulin resistance. Science 259: 87-91.

Hotamisligil GS, Arner P, Caro JF, Atkinson RL, Spiegelman BM. 1995. Increased adipose tissue expression of tumor necrosis factor- $\alpha$ in human obesity and insulin resistance. J Clin Invest 95: 2409-2415.

Hsueh AJ, Dahl KD, Vaughan J, Tucker E, Rivier J, Bardin CW, Vale W. 1987. Heterodimers and homodimers of inhibin subunits have different paracrine action in the modulation of luteinizing hormone-stimulated androgen biosynthesis. Proc Natl Acad Sci 84: 5082-5086.

Huang HM, Chiou HY, Chang JL. 2006. Activin A induces erythroid gene expressions and inhibits mitogenic cytokine-mediated K562 colony formation by activating p38 MAPK. J Cell Biochem 98: 789-797.

Hübner G, Hu Q, Smola H, Werner S. 1996. Strong induction of activin expression after injury suggests an important role of activin in wound repair. Dev Biol 173: 490498.

Hübner G, Alzheimer C, Werner S. 1999. Activin: A novel player in tissue repair processes. Histol Histopathol 14: 295-304.

Hughes PE, Alexi T, Williams CE, Clark RG, Gluckman PD. 1999. Administration of recombinant human Activin-A 
has powerful neurotrophic effects on select striatal phenotypes in the quinolinic acid lesion model of Huntington's disease. Neuroscience 92: 197-209.

Ikenoue T, Jingushi S, Urabe K, Okazaki K, Iwamoto Y. 1999. Inhibitory effects of activin-A on osteoblast differentiation during cultures of fetal rat calvarial cells. J Cell Biochem 75: 206-214.

Illingworth PJ, Groome NP, Byrd W, Rainey WE, McNeilly AS, Mather JP, Bremner WJ. 1996. Inhibin-B: A likely candidate for the physiologically important form of inhibin in men. J Clin Endocrinol Metab 81: 1321-1325.

Incorvaia L, Badalamenti G, Rini G, Arcara C, Fricano S, Sferrazza C, Di Trapani D, Gebbia N, Leto G. 2007. MMP2, MMP-9 and activin A blood levels in patients with breast cancer or prostate cancer metastatic to the bone. Anticancer Res 27: 1519-1525.

Inoue S, Nomura S, Hosoi T, Ouchi Y, Orimo H, Muramatsu M. 1994. Localization of follistatin, an activin-binding protein, in bone tissues. Calcif Tissue Int 55: 395-397.

Ishisaki A, Yamato K, Nakao A, Nonaka K, Ohguchi M, ten Dijke P, Nishihara T. 1998. Smad7 is an activin-inducible inhibitor of activin-induced growth arrest and apoptosis in mouse B cells. J Biol Chem 273: 24293-24296.

Ishisaki A, Yamato K, Hashimoto S, Nakao A, Tamaki K, Nonaka K, ten Dijke P, Sugino H, Nishihara T. 1999. Differential inhibition of Smad6 and Smad7 on bone morphogenetic protein- and activin-mediated growth arrest and apoptosis in B cells. J Biol Chem 274: 13637-13642.

Itman C, Small C, Griswold M, Nagaraja AK, Matzuk MM, Brown CW, Jans DA, Loveland KL. 2009. Developmentally regulated SMAD2 and SMAD3 utilization directs activin signaling outcomes. Dev Dyn 238: 1688-1700.

Iwahori Y, Saito H, Torii K, Nishiyama N. 1997. Activin exerts a neurotrophic effect on cultured hippocampal neurons. Brain Res 760: 52-58.

Jazwinska A, Badakov R, Keating MT. 2007. Activin- $\beta$ A signaling is required for zebrafish fin regeneration. Curr Biol 17: 1390-1395.

Jhaveri S, Erzurumlu RS, Chiaia N, Kumar TR, Matzuk MM. 1998. Defective whisker follicles and altered brainstem patterns in activin and follistatin knockout mice. Mol Cell Neurosci 12: 206-219.

Jones KL, de Kretser DM, Clarke IJ, Scheerlinck JP, Phillips DJ. 2004. Characterisation of the rapid release of activin A following acute lipopolysaccharide challenge in the ewe. J Endocrinol 182: 69-80.

Jones RL, Findlay JK, Farnworth PG, Robertson DM, Wallace E, Salamonsen LA. 2006. Activin A and inhibin A differentially regulate human uterine matrix metalloproteinases: potential interactions during decidualization and trophoblast invasion. Endocrinology 147: 724-732.

Jones KL, Mansell A, Patella S, Scott BJ, Hedger MP, de Kretser DM, Phillips DJ. 2007. Activin A is a critical component of the inflammatory response, and its binding protein, follistatin, reduces mortality in endotoxemia. Proc Natl Acad Sci 104: 16239-16244.

Kaiser UB, Lee BL, Carroll RS, Unabia G, Chin WW, Childs GV. 1992. Follistatin gene expression in the pituitary: Localization in gonadotropes and folliculostellate cells in diestrous rats. Endocrinology 130: 3048-3056.
Kaiser UB, Sabbagh E, Katzenellenbogen RA, Conn PM, Chin WW. 1995. A mechanism for the differential regulation of gonadotropin subunit gene expression by gonadotropin-releasing hormone. Proc Natl Acad Sci 92: 12280-12284.

Kariyawasam HH, Semitekolou M, Robinson DS, Xanthou G. 2011. Activin-A: A novel critical regulator of allergic asthma. Clin Exp Allergy 41: 1505-1514.

Kelber JA, Shani G, Booker EC, Vale WW, Gray PC. 2007. Cripto is a non-competitive activin antagonist that forms analogous signaling complexes with activin and nodal. $J$ Biol Chem 283: 4490-5000.

Kelber JA, Panopoulos AD, Shani G, Booker EC, Belmonte JC, Vale WW, Gray PC. 2009. Blockade of Cripto binding to cell surface GRP78 inhibits oncogenic Cripto signaling via MAPK/PI3K and Smad2/3 pathways. Oncogene 28: 2324-2336.

Kessler DS, Melton DA. 1995. Induction of dorsal mesoderm by soluble, mature Vg1 protein. Development 121: 2155-2164.

Kim SK, Hebrok M, Li E, Oh SP, Schrewe H, Harmon EB, Lee JS, Melton DA. 2000. Activin receptor patterning of foregut organogenesis. Genes Dev 14: 1866-1871.

Kimura F, Sidis Y, Bonomi L, Xia Y, Schneyer A. 2010. The follistatin-288 isoform alone is sufficient for survival but not for normal fertility in mice. Endocrinology 151: 1310-1319.

Kimura F, Bonomi LM, Schneyer AL. 2011. Follistatin regulates germ cell nest breakdown and primordial follicle formation. Endocrinology 152: 697-706.

Kipp JL, Kilen SM, Woodruff TK, Mayo KE. 2007. Activin regulates estrogen receptor gene expression in the mouse ovary. J Biol Chem 282: 36755-36765.

Knight PG, Glister C. 2006. TGF- $\beta$ superfamily members and ovarian follicle development. Reproduction 132: 191-206.

Kogame M, Matsuo S, Nakatani M, Kurisaki A, Nishitani H, Tsuchida K, Sugino H. 2006. ALK7 is a novel marker for adipocyte differentiation. J Med Invest 53: 238-245.

Koncarevic A, Kajimura S, Cornwall-Brady M, Andreucci A, Pullen A, Sako D, Kumar R, Grinberg AV, Liharska K, Ucran JA, et al. 2012. A novel therapeutic approach to treating obesity through modulation of TGF $\beta$ signaling. Endocrinology 153: 3133-3146.

Kotler DP. 2000. Cachexia. Ann Intern Med 133: 622-634.

Krieglstein K, Suter-Crazzolara C, Fischer WH, Unsicker K. 1995. TGF- $\beta$ superfamily members promote survival of midbrain dopaminergic neurons and protect them against $\mathrm{MPP}^{+}$toxicity. EMBO J 14: 736-742.

Kumanov P, Nandipati K, Tomova A, Agarwal A. 2006. Inhibin $B$ is a better marker of spermatogenesis than other hormones in the evaluation of male factor infertility. Fertil Steril 86: $332-338$.

Kumar TR, Wang Y, Matzuk MM. 1996. Gonadotropins are essential modifier factors for gonadal tumor development in inhibin-deficient mice. Endocrinology 137: 4210-4216.

Kumar TR, Palapattu G, Wang P, Woodruff TK, Boime I, Byrne MC, Matzuk MM. 1999. Transgenic models to study gonadotropin function: The role of follicle-stimu- 
lating hormone in gonadal growth and tumorigenesis Mol Endocrinol 13: 851-865.

Kupershmidt L, Amit T, Bar-Am O, Youdim MB, Blumenfeld Z. 2007. The neuroprotective effect of Activin A and B: Implication for neurodegenerative diseases. J Neurochem 103: 962-971.

Lacasa D, Taleb S, Keophiphath M, Miranville A, Clément K. 2007. Macrophage-secreted factors impair human adipogenesis: Involvement of proinflammatory state in preadipocytes. Endocrinology 148: 868-877.

Lau AL, Kumar TR, Nishimori K, Bonadio J, Matzuk MM. 2000. Activin $\beta C$ and $\beta E$ genes are not essential for mouse liver growth, differentiation, and regeneration. Mol Cell Biol 20: 6127-6137.

Lecuit T, Brook WJ, Ng M, Calleja M, Sun H, Cohen SM. 1996. Two distinct mechanisms for long-range patterning by Decapentaplegic in the Drosophila wing. Nature 381: 387-393.

Lee SJ, McPherron AC. 2001. Regulation of myostatin activity and muscle growth. Proc Natl Acad Sci 98: 9306-9311.

Lee SJ, Reed LA, Davies MV, Girgenrath S, Goad ME, Tomkinson KN, Wright JF, Barker C, Ehrmantraut G, Holmstrom J, et al. 2005. Regulation of muscle growth by multiple ligands signaling through activin type II receptors. Proc Natl Acad Sci 102: 18117-18122.

Lejeune H, Chuzel F, Sanchez P, Durand P, Mather JP, Saez JM. 1997. Stimulating effect of both human recombinant inhibin A and activin A on immature porcine Leydig cell functions in vitro. Endocrinology 138: 4783-4791.

Lenton EA, de Kretser DM, Woodward AJ, Robertson DM. 1991. Inhibin concentrations throughout the menstrual cycles of normal, infertile, and older women compared with those during spontaneous conception cycles. J Clin Endocrinol Metab 73: 1180-1190.

Leto G, Incorvaia L, Badalamenti G, Tumminello FM, Gebbia N, Flandina C, Crescimanno M, Rini G. 2006. Activin A circulating levels in patients with bone metastasis from breast or prostate cancer. Clin Exp Metastasis 23: 117122.

Lewis KA, Gray PC, Blount AL, MacConell LA, Wiater E, Bilezikjian LM, Vale W. 2000. Betaglycan binds inhibin and can mediate functional antagonism of activin signalling. Nature 404: 411-414.

Li Q, Graff JM, O'Connor AE, Loveland KL, Matzuk MM. 2007. SMAD3 regulates gonadal tumorigenesis. Mol Endocrinol 21: 2472-2486.

Li L, Shen JJ, Bournat JC, Huang L, Chattopadhyay A, Li Z, Shaw C, Graham BH, Brown CW. 2009. Activin signaling: Effects on body composition and mitochondrial energy metabolism. Endocrinology 150: 3521-3529.

Li S, Shimono C, Norioka N, Nakano I, Okubo T, Yagi Y, Hayashi M, Sato Y, Fujisaki H, Hattori S, et al. 2010. Activin A binds to perlecan through its pro-region that has heparin/heparan sulfate binding activity. J Biol Chem 285: 36645-36655.

Lima AR, Martinez PF, Okoshi K, Guizoni DM, Zornoff LA, Campos DH, Oliveira SA Jr, Bonomo C, Pai-Silva MD, Okoshi MP. 2010. Myostatin and follistatin expression in skeletal muscles of rats with chronic heart failure. Int $J$ Exp Pathol 91: 54-62.
Lin T, Calkins JK, Morris PL, Vale W, Bardin CW. 1989. Regulation of Leydig cell function in primary culture by inhibin and activin. Endocrinology 125: 2134-2140.

Lin X, Duan X, Liang YY, Su Y, Wrighton KH, Long J, Hu M, Davis CM, Wang J, Brunicardi FC, et al. 2006. PPM1A functions as a Smad phosphatase to terminate TGF $\beta$ signaling. Cell 125: 915-928.

Lin SY, Craythorn RG, O'Connor AE, Matzuk MM, Girling JE, Morrison JR, de Kretser DM. 2008. Female infertility and disrupted angiogenesis are actions of specific follistatin isoforms. Mol Endocrinol 22: 415-429.

Ling N, Ying SY, Ueno N, Esch F, Denoroy L, Guillemin R. 1985. Isolation and partial characterization of a $M_{\mathrm{r}}$ 32,000 protein with inhibin activity from porcine follicular fluid. Proc Natl Acad Sci 82: 7217-7221.

Ling N, Ying SY, Ueno N, Shimasaki S, Esch F, Hotta M, Guillemin R. 1986a. A homodimer of the $\beta$-subunits of inhibin A stimulates the secretion of pituitary follicle stimulating hormone. Biochem Biophys Res Commun 138: 1129-1137.

Ling N, Ying SY, Ueno N, Shimasaki S, Esch F, Hotta M, Guillemin R. 1986b. Pituitary FSH is released by a heterodimer of the $\beta$-subunits from the two forms of inhibin. Nature 321: 779-782.

Linko R, Okkonen M, Pettila V, Perttila J, Parviainen I, Ruokonen E, Tenhunen J, Ala-Kokko T, Varpula T, group FI-s. 2009. Acute respiratory failure in intensive care units. FINNALI: A prospective cohort study. Intensive Care Med 35: 1352-1361.

Looyenga BD, Hammer GD. 2006. Origin and identity of adrenocortical tumors in inhibin knockout mice: Implications for cellular plasticity in the adrenal cortex. Mol Endocrinol 20: 2848-2863.

Lopez-Casillas F, Cheifetz S, Doody J, Andres JL, Lane WS, Massagué J. 1991. Structure and expression of the membrane proteoglycan betaglycan, a component of the TGF$\beta$ receptor system. Cell 67: 785-795.

Lotinun S, Pearsall RS, Davies MV, Marvell TH, Monnell TE, Ucran J, Fajardo RJ, Kumar R, Underwood KW, Seehra J, et al. 2010. A soluble activin receptor Type IIA fusion protein (ACE-011) increases bone mass via a dual anabolic-antiresorptive effect in Cynomolgus monkeys. Bone 46: $1082-1088$.

Loveland KL, Bakker M, Meehan T, Christy E, von Schonfeldt V, Drummond A, de Kretser D. 2003. Expression of $B a m b i$ is widespread in juvenile and adult rat tissues and is regulated in male germ cells. Endocrinology 144: 41804186.

Lu C, Yang W, Chen M, Liu T, Yang J, Tan P, Li L, Hu X, Fan C, Hu Z, et al. 2009. Inhibin A inhibits follicle-stimulating hormone (FSH) action by suppressing its receptor expression in cultured rat granulosa cells. Mol Cell Endocrinol 298: $48-56$.

Lumeng CN, Bodzin JL, Saltiel AR. 2007. Obesity induces a phenotypic switch in adipose tissue macrophage polarization. J Clin Invest 117: 175-184.

Lumeng CN, DelProposto JB, Westcott DJ, Saltiel AR. 2008. Phenotypic switching of adipose tissue macrophages with obesity is generated by spatiotemporal differences in macrophage subtypes. Diabetes 57: 3239-3246.

MacConell LA, Leal AM, Vale WW. 2002. The distribution of betaglycan protein and mRNA in rat brain, pituitary, and 
M. Namwanje and C.W. Brown

gonads: Implications for a role for betaglycan in inhibinmediated reproductive functions. Endocrinology 143: 1066-1075.

Maeshima A, Nojima Y, Kojima I. 2002. Activin A: An autocrine regulator of cell growth and differentiation in renal proximal tubular cells. Kidney Int 62: 446-454.

Magnusson B, Svensson PA, Carlsson LM, Sjöholm K. 2010. Activin B inhibits lipolysis in 3T3-L1 adipocytes. Biochem Biophys Res Commun 395: 373-376.

Maguer-Satta V, Bartholin L, Jeanpierre S, Ffrench M, Martel S, Magaud JP, Rimokh R. 2003. Regulation of human erythropoiesis by activin A, BMP2, and BMP4, members of the TGF $\beta$ family. Exp Cell Res 282: 110-120.

Makanji Y, Harrison CA, Stanton PG, Krishna R, Robertson DM. 2007. Inhibin A and B in vitro bioactivities are modified by their degree of glycosylation and their affinities to betaglycan. Endocrinology 148: 2309-2316.

Makanji Y, Walton KL, Wilce MC, Chan KL, Robertson DM, Harrison CA. 2008. Suppression of inhibin A biological activity by alterations in the binding site for betaglycan. $J$ Biol Chem 283: 16743-16751.

Makanji Y, Temple-Smith PD, Walton KL, Harrison CA, Robertson DM. 2009. Inhibin B is a more potent suppressor of rat follicle-stimulating hormone release than inhibin A in vitro and in vivo. Endocrinology 150: 47844793.

Makanji Y, Zhu J, Mishra R, Holmquist C, Wong WP, Schwartz NB, Mayo KE, Woodruff TK. 2014. Inhibin at 90: From discovery to clinical application, a historical review. Endocr Rev 35: 747-794.

Mantovani A, Sica A, Sozzani S, Allavena P, Vecchi A, Locati M. 2004. The chemokine system in diverse forms of macrophage activation and polarization. Trends Immunol 25: 677-686.

Marchetti C, Hamdane M, Mitchell V, Mayo K, Devisme L, Rigot JM, Beauvillain JC, Hermand E, Defossez A. 2003. Immunolocalization of inhibin and activin $\alpha$ and $\beta B$ subunits and expression of corresponding messenger RNAs in the human adult testis. Biol Reprod 68: 230-235.

Martinez FO, Sica A, Mantovani A, Locati M. 2008. Macrophage activation and polarization. Front Biosci 13: $453-$ 461.

Mason AJ, Berkemeier LM, Schmelzer CH, Schwall RH. 1989. Activin B: Precursor sequences, genomic structure and in vitro activities. Mol Endocrinol 3: 1352-1358.

Mason AJ, Farnworth PG, Sullivan J. 1996. Characterization and determination of the biological activities of noncleavable high molecular weight forms of inhibin A and activin A. Mol Endocrinol 10: 1055-1065.

Massagué J. 1998. TGF- $\beta$ signal transduction. Annu Rev Biochem 67: 753-791.

Massagué J, Chen YG. 2000. Controlling TGF- $\beta$ signaling. Genes Dev 14: 627-644.

Mather JP, Attie KM, Woodruff TK, Rice GC, Phillips DM. 1990. Activin stimulates spermatogonial proliferation in germ-Sertoli cell cocultures from immature rat testis. Endocrinology 127: 3206-3214.

Mathews LS, Vale WW. 1991. Expression cloning of an activin receptor, a predicted transmembrane serine kinase. Cell 65: 973-982.
Mathews LS, Vale WW, Kintner CR. 1992. Cloning of a second type of activin receptor and functional characterization in Xenopus embryos. Science 255: 1702-1705.

Matsuse T, Ikegami A, Ohga E, Hosoi T, Oka T, Kida K, Fukayama M, Inoue S, Nagase T, Ouchi Y, et al. 1996. Expression of immunoreactive activin A protein in remodeling lesions associated with interstitial pulmonary fibrosis. Am J Pathol 148: 707-713.

Matzuk MM, Finegold MJ, Su J-GJ, Hsueh AJW, Bradley A. 1992. $\alpha$-Inhibin is a tumour-suppressor gene with gonadal specificity in mice. Nature 360: 313-319.

Matzuk MM, Finegold MJ, Mishina Y, Bradley A, Behringer RR. 1995a. Synergistic effects of inhibins and mullerianinhibiting substance on testicular tumorigenesis. Mol Endocrinol 9: 1337-1345.

Matzuk MM, Kumar TR, Bradley A. 1995b. Different phenotypes for mice deficient in either activins or activin receptor type II. Nature 374: 356-360.

Matzuk MM, Kumar TR, Vassalli A, Bickenbach JR, Roop DR, Jaenisch R, Bradley A. 1995c. Functional analysis of activins during mammalian development. Nature 374: 354-356.

Matzuk MM, Lu N, Vogel H, Sellheyer K, Roop DR, Bradley A. 1995d. Multiple defects and perinatal death in mice deficient in follistatin. Nature 374: 360-363.

Mauduit C, Chauvin MA, de Peretti E, Morera AM, Benahmed M. 1991. Effect of activin A on dehydroepiandrosterone and testosterone secretion by primary immature porcine Leydig cells. Biol Reprod 45: 101-109.

McCullagh DR. 1932. Dual endocrine activity of the testes. Science 76: $19-20$.

McLachlan RI, Robertson DM, Healy DL, Burger HG, de Kretser DM. 1987. Circulating immunoreactive inhibin levels during the normal human menstrual cycle. J Clin Endocrinol Metab 65: 954-961.

McMullen ML, Cho BN, Yates CJ, Mayo KE. 2001. Gonadal pathologies in transgenic mice expressing the rat inhibin $\alpha$-subunit. Endocrinology 142: 5005-5014.

Meehan T, Schlatt S, O’Bryan MK, de Kretser DM, Loveland KL. 2000. Regulation of germ cell and Sertoli cell development by activin, follistatin, and FSH. Dev Biol 220: 225-237.

Mellor SL, Ball EM, O'Connor AE, Ethier JF, Cranfield M, Schmitt JF, Phillips DJ, Groome NP, Risbridger GP. 2003. Activin $\beta C$-subunit heterodimers provide a new mechanism of regulating activin levels in the prostate. Endocrinology 144: 4410-4419.

Mendis SH, Meachem SJ, Sarraj MA, Loveland KL. 2010. Activin A balances Sertoli and germ cell proliferation in the fetal mouse testis. Biol Reprod 84: 379-391.

Merino R, Macias D, Ganan Y, Rodriguez-Leon J, Economides AN, Rodriguez-Esteban C, Izpisua-Belmonte JC, Hurle JM. 1999. Control of digit formation by activin signalling. Development 126: 2161-2170.

Michel U, Ebert S, Schneider O, Shintani Y, Bunkowski S, Smirnov A, Stringaris A, Gerber J, Bruck W, Nau R. 2000. Follistatin (FS) in human cerebrospinal fluid and regulation of FS expression in a mouse model of meningitis. Eur J Endocrinol 143: 809-816.

Michel U, Ebert S, Phillips D, Nau R. 2003. Serum concentrations of activin and follistatin are elevated and run in 
parallel in patients with septicemia. Eur J Endocrinol 148 559-564.

Miro F, Hillier SG. 1996. Modulation of granulosa cell deoxyribonucleic acid synthesis and differentiation by activin. Endocrinology 137: 464-468.

Mishina Y, Rey R, Finegold MJ, Matzuk MM, Josso N, Cate RL, Behringer RR. 1996. Genetic analysis of the Mullerian-inhibiting substance signal transduction pathway in mammalian sexual differentiation. Genes Dev 10: 2577 2587.

Mithraprabhu S, Mendis S, Meachem SJ, Tubino L, Matzuk MM, Brown CW, Loveland KL. 2010. Activin bioactivity affects germ cell differentiation in the postnatal mouse testis in vivo. Biol Reprod 82: 980-990.

Miyamoto K, Hasegawa Y, Fukuda M, Nomura M, Igarashi M, Kangawa K, Matsuo H. 1985. Isolation of porcine follicular fluid inhibin of $32 \mathrm{~K}$ daltons. Biochem Biophys Res Commun 129: 396-403.

Molloy CJ, Taylor DS, Pawlowski JE. 1999. Novel cardiovascular actions of the activins. J Endocrinology 161: 179185.

Mukherjee A, Sidis Y, Mahan A, Raher MJ, Xia Y, Rosen ED, Bloch KD, Thomas MK, Schneyer AL. 2007. FSTL3 deletion reveals roles for TGF- $\beta$ family ligands in glucose and fat homeostasis in adults. Proc Natl Acad Sci 104: 1348 1353.

Muller MR, Zheng F, Werner S, Alzheimer C. 2006. Transgenic mice expressing dominant-negative activin receptor IB in forebrain neurons reveal novel functions of activin at glutamatergic synapses. J Biol Chem 281: 2907629084.

Munz B, Hübner G, Tretter Y, Alzheimer C, Werner S. 1999a. A novel role of activin in inflammation and repair J Endocrinology 161: 187-193.

Munz B, Smola H, Engelhardt F, Bleuel K, Brauchle M, Lein I, Evans LW, Huylebroeck D, Balling R, Werner S. 1999b. Overexpression of activin A in the skin of transgenic mice reveals new activities of activin in epidermal morphogenesis, dermal fibrosis and wound repair. $E M B O J$ 18: 5205-5215.

Murata M, Eto Y, Shibai H, Sakai M. 1988. Erythroid differentiation factor is encoded by the same mRNA as that of the inhibin $\beta A$ chain. Proc Natl Acad Sci 85: 2434-2438.

Muttukrishna S. 2004. Role of inhibin in normal and highrisk pregnancy. Semin Reprod Med 22: 227-234.

Muttukrishna S, George L, Fowler PA, Groome NP, Knight PG. 1995. Measurement of serum concentrations of inhibin-A ( $\alpha-\beta$ A dimer) during human pregnancy. Clin Endocrinol (Oxf) 42: 391-397.

Myers M, Mansouri-Attia N, James R, Peng J, Pangas SA. 2013. GDF9 modulates the reproductive and tumor phenotype of female Inha-null mice. Biol Reprod 88: 86.

Nagaraja AK, Agno JE, Kumar TR, Matzuk MM. 2008. Luteinizing hormone promotes gonadal tumorigenesis in inhibin-deficient mice. Mol Cell Endocrinol 294: 19-28.

Nakamura T, Takio K, Eto Y, Shibai H, Titani K, Sugino H. 1990. Activin-binding protein from rat ovary is follistatin. Science 247: 836-838.

Nellen D, Burke R, Struhl G, Basler K. 1996. Direct and longrange action of a DPP morphogen gradient. Cell 85: $357-368$.
Nicholls PK, Stanton PG, Chen JL, Olcorn JS, Haverfield JT Qian H, Walton KL, Gregorevic P, Harrison CA. 2012. Activin signaling regulates Sertoli cell differentiation and function. Endocrinology 153: 6065-6077.

Nomura M, Li E. 1998. Smad2 role in mesoderm formation, left-right patterning and craniofacial development. $\mathrm{Na}-$ ture 393: 786-790.

Norwitz ER, Xu S, Jeong KH, Bedecarrats GY, Winebrenner LD, Chin WW, Kaiser UB. 2002. Activin A augments GnRH-mediated transcriptional activation of the mouse GnRH receptor gene. Endocrinology 143: 985-997.

O’Bryan MK, Sebire KL, Gerdprasert O, Hedger MP, Hearn MT, de Kretser DM. 2000. Cloning and regulation of the rat activin $\beta E$ subunit. J Mol Endocrinol 24: 409-418.

O'Connor AE, McFarlane JR, Hayward S, Yohkaichiya T, Groome NP, de Kretser DM. 1999. Serum activin A and follistatin concentrations during human pregnancy: A cross-sectional and longitudinal study. Hum Reprod 14: 827-832.

Oda S, Nishimatsu S, Murakami K, Ueno N. 1995. Molecular cloning and functional analysis of a new activin $\beta$ subunit: A dorsal mesoderm-inducing activity in Xenopus. Biochem Biophys Res Commun 210: 581-588.

Ogawa K, Abe K, Kurosawa N, Kurohmaru M, Sugino H, Takahashi M, Hayashi Y. 1993. Expression of $\alpha, \beta A$ and $\beta B$ subunits of inhibin or activin and follistatin in rat pancreatic islets. FEBS Lett 319: 217-220.

Ogawa K, Funaba M, Chen Y, Tsujimoto M. 2006. Activin A functions as a Th2 cytokine in the promotion of the alternative activation of macrophages. J Immunol 177: 6787-6794.

Ogihara T, Watada H, Kanno R, Ikeda F, Nomiyama T, Tanaka Y, Nakao A, German MS, Kojima I, Kawamori R. 2003. p38 MAPK is involved in activin A- and hepatocyte growth factor-mediated expression of pro-endocrine gene neurogenin 3 in AR42J-B13 cells. J Biol Chem 278: 21693-21700.

Oh SP, Li E. 1997. The signaling pathway mediated by the type IIB activin receptor controls axial patterning and lateral asymmetry in the mouse. Genes Dev 11: 18121826.

Ohga E, Matsuse T, Teramoto S, Katayama H, Nagase T, Fukuchi Y, Ouchi Y. 1996. Effects of activin A on proliferation and differentiation of human lung fibroblasts. Biochem Biophys Res Commun 228: 391-396.

Ohga E, Matsuse T, Teramoto S, Ouchi Y. 2000. Activin receptors are expressed on human lung fibroblast and activin A facilitates fibroblast-mediated collagen gel contraction. Life Sci 66: 1603-1613.

Onichtchouk D, Chen YG, Dosch R, Gawantka V, Delius H, Massagué J, Niehrs C. 1999. Silencing of TGF- $\beta$ signalling by the pseudoreceptor BAMBI. Nature 401: $480-$ 485.

Otsuka F, Moore RK, Iemura S, Ueno N, Shimasaki S. 2001. Follistatin inhibits the function of the oocyte-derived factor BMP-15. Biochem Biophys Res Commun 289: 961-966.

Oue Y, Kanatani H, Kiyoki M, Eto Y, Ogata E, Matsumoto T. 1994. Effect of local injection of activin A on bone formation in newborn rats. Bone 15: 361-366. 
Pangas SA, Jorgez CJ, Tran M, Agno J, Li X, Brown CW, Kumar TR, Matzuk MM. 2007. Intraovarian activins are required for female fertility. Mol Endocrinol 21: $2458-2471$.

Parker L, Stathakis DG, Arora K. 2004. Regulation of BMP and activin signaling in Drosophila. Prog Mol Subcell Biol 34: 73-101.

Parker L, Ellis JE, Nguyen MQ, Arora K. 2006. The divergent TGF- $\beta$ ligand Dawdle utilizes an activin pathway to influence axon guidance in Drosophila. Development 133: 4981-4991.

Patella S, Phillips DJ, Tchongue J, de Kretser DM, Sievert W. 2006. Follistatin attenuates early liver fibrosis: Effects on hepatic stellate cell activation and hepatocyte apoptosis. Am J Physiol Gastrointest Liver Physiol 290: G137-G144.

Pearsall RS, Canalis E, Cornwall-Brady M, Underwood KW, Haigis B, Ucran J, Kumar R, Pobre E, Grinberg A, Werner $\mathrm{ED}$, et al. 2008. A soluble activin type IIA receptor induces bone formation and improves skeletal integrity. Proc Natl Acad Sci 105: 7082-7087.

Pearson S, Sroczynska P, Lacaud G, Kouskoff V. 2008. The stepwise specification of embryonic stem cells to hematopoietic fate is driven by sequential exposure to Bmp4, activin A, bFGF and VEGF. Development 135: 15251535.

Perrien DS, Achenbach SJ, Bledsoe SE, Walser B, Suva LJ, Khosla S, Gaddy D. 2006. Bone turnover across the menopause transition: Correlations with inhibins and follicle-stimulating hormone. J Clin Endocrinol Metab 91: $1848-1854$.

Perrien DS, Akel NS, Edwards PK, Carver AA, Bendre MS, Swain FL, Skinner RA, Hogue WR, Nicks KM, Pierson $\mathrm{TM}$, et al. 2007. Inhibin A is an endocrine stimulator of bone mass and strength. Endocrinology 148: 1654-1665.

Petraglia F, Vaughan J, Vale W. 1989. Inhibin and activin modulate the release of gonadotropin-releasing hormone, human chorionic gonadotropin, and progesterone from cultured human placental cells. Proc Natl Acad Sci 86: 5114-5117.

Petraglia F, Gallinelli A, Grande A, Florio P, Ferrari S, Genazzani AR, Ling N, DePaolo LV. 1994. Local production and action of follistatin in human placenta. J Clin Endocrinol Metab 78: 205-210.

Petraglia F, Aguzzoli L, Gallinelli A, Florio P, Zonca M, Benedetto C, Woodruff K. 1995a. Hypertension in pregnancy: Changes in activin A maternal serum concentration. Placenta 16: 447-454.

Petraglia F, De Vita D, Gallinelli A, Aguzzoli L, Genazzan AR, Romero R, Woodruff TK. 1995b. Abnormal concentration of maternal serum activin-A in gestational diseases. J Clin Endocrinol Metab 80: 558-561.

Petrakou E, Fotopoulos S, Anagnostakou M, Anatolitou F, Samitas K, Semitekolou M, Xanthou G, Xanthou M. 2013. Activin-A exerts a crucial anti-inflammatory role in neonatal infections. Pediatr Res 74: 675-681.

Phillips DJ, de Kretser DM, Hedger MP. 2009. Activin and related proteins in inflammation: Not just interested bystanders. Cytokine Growth Factor Rev 20: 153-164.

Pierson TM, Wang Y, DeMayo FJ, Matzuk MM, Tsai SY Omalley BW. 2000. Regulable expression of inhibin A in wild-type and inhibin $\alpha$ null mice. Mol Endocrinol 14: $1075-1085$.
Pistilli EE, Bogdanovich S, Goncalves MD, Ahima RS, Lachey J, Seehra J, Khurana T. 2011. Targeting the activin type IIB receptor to improve muscle mass and function in the mdx mouse model of Duchenne muscular dystrophy. Am J Pathol 178: 1287-1297.

Qiu W, Li X, Tang H, Huang AS, Panteleyev AA, Owens DM, Su GH. 2011. Conditional activin receptor type 1B (Acvr1b) knockout mice reveal hair loss abnormality. J Invest Dermatol 131: 1067-1076.

Rabinovici J, Spencer SJ, Jaffe RB. 1990. Recombinant human activin-A promotes proliferation of human luteinized preovulatory granulosa cells in vitro. J Clin Endocrinol Metab 71: 1396-1398.

Reilly KM, Melton DA. 1996. Short-range signaling by candidate morphogens of the TGF $\beta$ family and evidence for a relay mechanism of induction. Cell 86: 743-754.

Reissmann E, Jornvall H, Blokzijl A, Andersson O, Chang C, Minchiotti G, Persico MG, Ibanez CF, Brivanlou AH. 2001. The orphan receptor ALK7 and the Activin receptor ALK4 mediate signaling by Nodal proteins during vertebrate development. Genes Dev 15: 2010-2022.

Riccardi E, Grieco V, Verganti S, Finazzi M. 2007. Immunohistochemical diagnosis of canine ovarian epithelial and granulosa cell tumors. J Vet Diagn Invest 19: 431-435.

Risbridger GP, Schmitt JF, Robertson DM. 2001. Activins and inhibins in endocrine and other tumors. Endocr Rev 22: 836-858.

Risbridger GP, Ball EM, Wang H, Mellor SL, Peehl DM. 2004. Re-evaluation of inhibin $\alpha$ subunit as a tumour suppressor in prostate cancer. Mol Cell Endocrinol 225: $73-76$.

Rivier J, Spiess J, McClintock R, Vaughan J, Vale W. 1985. Purification and partial characterization of inhibin from porcine follicular fluid. Biochem Biophys Res Commun 133: $120-127$.

Roberts VJ, Barth SL. 1994. Expression of messenger ribonucleic acids encoding the inhibin/activin system during mid- and late-gestation rat embryogenesis. Endocrinology 134: 914-923.

Roberts VJ, Barth S, el-Roeiy A, Yen SS. 1993. Expression of inhibin/activin subunits and follistatin messenger ribonucleic acids and proteins in ovarian follicles and the corpus luteum during the human menstrual cycle. $J$ Clin Endocrinol Metab 77: 1402-1410.

Roberts VJ, Barth SL, Meunier H, Vale W. 1996. Hybridization histochemical and immunohistochemical localization of inhibin/activin subunits and messenger ribonucleic acids in the rat brain. J Comp Neurol 364: 473-493.

Roberts HJ, Hu S, Qiu Q, Leung PC, Caniggia I, Gruslin A, Tsang B, Peng C. 2003. Identification of novel isoforms of activin receptor-like kinase 7 (ALK7) generated by alternative splicing and expression of ALK7 and its ligand, Nodal, in human placenta. Biol Reprod 68: 1719-1726.

Robertson DM, Foulds LM, Leversha L, Morgan FJ, Hearn MT, Burger HG, Wettenhall RE, de Kretser DM. 1985. Isolation of inhibin from bovine follicular fluid. Biochem Biophys Res Commun 126: 220-226.

Robertson DM, Hayward S, Irby D, Jacobsen J, Clarke L, McLachlan RI, de Kretser DM. 1988. Radioimmunoassay of rat serum inhibin: Changes after PMSG stimulation and gonadectomy. Mol Cell Endocrinol 58: 1-8. 
Robinson GW, Hennighausen L. 1997. Inhibins and activins regulate mammary epithelial cell differentiation through mesenchymal-epithelial interactions. Development 124: 2701-2708.

Roy S, Huang H, Liu S, Kornberg TB. 2014. Cytonememediated contact-dependent transport of the Drosophila decapentaplegic signaling protein. Science 343: 1244624.

Sakai R, Fujita S, Horie T, Ohyama T, Miwa K, Maki T, Okimoto N, Nakamura T, Eto Y. 2000. Activin increases bone mass and mechanical strength of lumbar vertebrae in aged ovariectomized rats. Bone 27: 91-96.

Samad TA, Rebbapragada A, Bell E, Zhang Y, Sidis Y, Jeong SJ, Campagna JA, Perusini S, Fabrizio DA, Schneyer AL, et al. 2005. DRAGON, a bone morphogenetic protein coreceptor. J Biol Chem 280: 14122-14129.

Savage C, Das P, Finelli AL, Townsend SR, Sun CY, Baird SE, Padgett RW. 1996. Caenorhabditis elegans genes sma-2, sma-3, and sma-4 define a conserved family of transforming growth factor b pathway components. Proc Natl Acad Sci 93: 790-794.

Savov JD, Gavett SH, Brass DM, Costa DL, Schwartz DA. 2002. Neutrophils play a critical role in development of LPS-induced airway disease. Am J Physiol Lung Cell Mol Physiol 283: L952-L962.

Schmitt J, Hotten G, Jenkins NA, Gilbert DJ, Copeland NG Pohl J, Schrewe H. 1996. Structure, chromosomal localization, and expression analysis of the mouse inhibin/ activin $\beta C$ (Inhbc) gene. Genomics 32: 358-366.

Schneyer A, Tortoriello D, Sidis Y, Keutmann H, Matsuzaki T, Holmes W. 2001. Follistatin-related protein (FSRP): A new member of the follistatin gene family. Mol Cell Endocrinol 180: 33-38.

Schneyer A, Schoen A, Quigg A, Sidis Y. 2003. Differential binding and neutralization of activins $\mathrm{A}$ and $\mathrm{B}$ by follistatin and follistatin like-3 (FSTL-3/FSRP/FLRG). Endocrinology 144: 1671-1674.

Schneyer AL, Wang Q, Sidis Y, Sluss PM. 2004. Differential distribution of follistatin isoforms: Application of a new FS315-specific immunoassay. JClin Endocrinol Metab 89: 5067-5075.

Schneyer AL, Sidis Y, Gulati A, Sun JL, Keutmann H, Krasney PA. 2008. Differential antagonism of activin, myostatin and growth and differentiation factor 11 by wild-type and mutant follistatin. Endocrinology 149: 4589-4595.

Schrewe H, Gendron-Maguire M, Harbison ML, Gridley T. 1994. Mice homozygous for a null mutation of activin $\beta B$ are viable and fertile. Mech Dev 47: 43-51.

Schubert D, Kimura H, LaCorbiere M, Vaughan J, Karr D, Fischer WH. 1990. Activin is a nerve cell survival molecule. Nature 344: 868-870.

Schwall RH, Robbins K, Jardieu P, Chang L, Lai C, Terrell TG. 1993. Activin induces cell death in hepatocytes in vivo and in vitro. Hepatology 18: 347-356.

Sealfon SC, Weinstein H, Millar RP. 1997. Molecular mechanisms of ligand interaction with the gonadotropin-releasing hormone receptor. Endocr Rev 18: 180-205.

Sekelsky JJ, Newfeld SJ, Raftery LA, Chartoff EH, Gelbart WM. 1995. Genetic characterization and cloning of mothers against $d p p$, a gene required for decapentaplegic function in Drosophila melanogaster. Genetics 139: 1347 1358.

Semitekolou M, Alissafi T, Aggelakopoulou M, Kourepini E, Kariyawasam HH, Kay AB, Robinson DS, Lloyd CM, Panoutsakopoulou V, Xanthou G. 2009. Activin-A induces regulatory $\mathrm{T}$ cells that suppress $\mathrm{T}$ helper cell immune responses and protect from allergic airway disease. J Exp Med 206: 1769-1785.

Serpe M, O'Connor MB. 2006. The metalloprotease tolloidrelated and its TGF- $\beta$-like substrate Dawdle regulate Drosophila motoneuron axon guidance. Development 133: 4969-4979.

Setchell BP, Jacks F. 1974. Inhibin-like activity in rete testis fluid. J Endocrinol 62: 675-676.

Shacham S, Harris D, Ben-Shlomo H, Cohen I, Bonfil D, Przedecki F, Lewy H, Ashkenazi IE, Seger R, Naor Z. 2001. Mechanism of GnRH receptor signaling on gonadotropin release and gene expression in pituitary gonadotrophs. Vitam Horm 63: 63-90.

Shani G, Fischer WH, Justice NJ, Kelber JA, Vale W, Gray PC. 2008. GRP78 and Cripto form a complex at the cell surface and collaborate to inhibit transforming growth factor $\beta$ signaling and enhance cell growth. Mol Cell Biol 28: $666-677$.

Sharpe RM, Turner KJ, McKinnell C, Groome NP, Atanassova N, Millar MR, Buchanan DL, Cooke PS. 1999. Inhibin B levels in plasma of the male rat from birth to adulthood: Effect of experimental manipulation of Sertoli cell number. J Androl 20: 94-101.

Shen MM. 2007. Nodal signaling: developmental roles and regulation. Development 134: 1023-1034.

Shiozaki M, Sakai R, Tabuchi M, Eto Y, Kosaka M, Shibai H. 1989. In vivo treatment with erythroid differentiation factor (EDF/activin A) increases erythroid precursors (CFU-E and BFU-E) in mice. Biochem Biophys Res Commun 165: 1155-1161.

Shiozaki M, Kosaka M, Eto Y. 1998. Activin A: A commitment factor in erythroid differentiation. Biochem Biophys Res Commun 242: 631-635.

Shiozaki M, Sakai R, Tabuchi M, Nakamura T, Sugino K, Sugino H, Eto Y. 1992. Evidence for the participation of endogenous activin A/erythroid differentiation factor in the regulation of erythropoiesis. Proc Natl Acad Sci 89: 1553-1556.

Shou W, Woodruff TK, Matzuk MM. 1997. Role of androgens in testicular tumor development in inhibin-deficient mice. Endocrinology 138: 5000-5005.

Sidis Y, Schneyer AL, Keutmann HT. 2005. Heparin and activin-binding determinants in follistatin and FSTL3. Endocrinology 146: 130-136.

Sidis Y, Mukherjee A, Keutmann H, Delbaere A, Sadatsuki M, Schneyer A. 2006. Biological activity of follistatin isoforms and follistatin-like-3 is dependent on differential cell surface binding and specificity for activin, myostatin, and bone morphogenetic proteins. Endocrinology 147: 3586-3597.

Sierra-Filardi E, Puig-Kroger A, Blanco FJ, Nieto C, Bragado R, Palomero MI, Bernabeu C, Vega MA, Corbi AL. 2011. Activin A skews macrophage polarization by promoting a proinflammatory phenotype and inhibiting the acquisition of anti-inflammatory macrophage markers. Blood 117: $5092-5101$ 
Silva CC, Groome NP, Knight PG. 1999. Demonstration of a suppressive effect of inhibin $\alpha$-subunit on the developmental competence of in vitro matured bovine oocytes. J Reprod Fertil 115: 381-388.

Sjöholm K, Palming J, Lystig TC, Jennische E, Woodruff TK, Carlsson B, Carlsson LM. 2006. The expression of inhibin $\beta B$ is high in human adipocytes, reduced by weight loss, and correlates to factors implicated in metabolic disease. Biochem Biophys Res Commun 344: 1308-1314.

Song J, Oh SP, Schrewe H, Nomura M, Lei H, Okano M, Gridley T, Li E. 1999. The type II activin receptors are essential for egg cylinder growth, gastrulation, and rostral head development in mice. Dev Biol 213: 157-169.

Sonoyama K, Rutatip S, Kasai T. 2000. Gene expression of activin, activin receptors, and follistatin in intestinal epithelial cells. Am J Physiol Gastrointest Liver Physiol 278: G89-G97.

Souza TA, Chen X, Guo Y, Sava P, Zhang J, Hill JJ, Yaworsky PJ, Qiu Y. 2008. Proteomic identification and functional validation of activins and bone morphogenetic protein 11 as candidate novel muscle mass regulators. Mol Endocrinol 22: 2689-2702.

Stamler R, Keutmann HT, Sidis Y, Kattamuri C, Schneyer A, Thompson TB. 2008. The structure of FSTL3.activin A complex. Differential binding of N-terminal domains influences follistatin-type antagonist specificity. J Biol Chem 283: 32831-32838.

Stenvers KL, Tursky ML, Harder KW, Kountouri N, Amatayakul-Chantler S, Grail D, Small C, Weinberg RA, Sizeland AM, Zhu HJ. 2003. Heart and liver defects and reduced transforming growth factor $\beta 2$ sensitivity in transforming growth factor $\beta$ type III receptor-deficient embryos. Mol Cell Biol 23: 4371-4385.

Sugino K, Kurosawa N, Nakamura T, Takio K, Shimasaki S, Ling N, Titani K, Sugino H. 1993. Molecular heterogeneity of follistatin, an activin-binding protein. Higher affinity of the carboxyl-terminal truncated forms for heparan sulfate proteoglycans on the ovarian granulosa cell. J Biol Chem 268: 15579-15587.

Sumi T, Tsuneyoshi N, Nakatsuji N, Suemori H. 2008. Defining early lineage specification of human embryonic stem cells by the orchestrated balance of canonical Wnt/ $\beta$-catenin, Activin/Nodal and BMP signaling. $D e-$ velopment 135: 2969-2979.

Suragani RN, Cadena SM, Cawley SM, Sako D, Mitchell D, Li R, Davies MV, Alexander MJ, Devine M, Loveday KS, et al. 2014. Transforming growth factor- $\beta$ superfamily ligand trap ACE-536 corrects anemia by promoting latestage erythropoiesis. Nat Med 20: 408-414.

Takamura K, Tsuchida K, Miyake H, Tashiro S, Sugino H. 2005. Activin and activin receptor expression changes in liver regeneration in rat. J Surg Res 126: 3-11.

Takehara-Kasamatsu Y, Tsuchida K, Nakatani M, Murakami T, Kurisaki A, Hashimoto O, Ohuchi H, Kurose H, Mori K, Kagami S, et al. 2007. Characterization of follistatinrelated gene as a negative regulatory factor for activin family members during mouse heart development. J Med Invest 54: 276-288.

Tanimoto Y, Tanimoto K, Sugiyama F, Horiguchi H, Murakami K, Yagami K, Fukamizu A. 1999. Male sterility in transgenic mice expressing activin $\beta A$ subunit gene in testis. Biochem Biophys Res Commun 259: 699-705. ten Dijke P, Ichijo H, Franzen P, Schulz P, Saras J, Toyoshima H, Heldin CH, Miyazono K. 1993. Activin receptor-like kinases: A novel subclass of cell-surface receptors with predicted serine/threonine kinase activity. Oncogene 8: 2879-2887.

Thompson TB, Woodruff TK, Jardetzky TS. 2003. Structures of an ActRIIB:activin A complex reveal a novel binding mode for TGF- $\beta$ ligand:receptor interactions. $E M B O$ J 22: $1555-1566$.

Thompson TB, Lerch TF, Cook RW, Woodruff TK, Jardetzky TS. 2005. The structure of the follistatin:activin complex reveals antagonism of both type I and type II receptor binding. Dev Cell 9: 535-543.

Tramullas M, Lantero A, Diaz A, Morchon N, Merino D, Villar A, Buscher D, Merino R, Hurle JM, Izpisua-Belmonte JC, et al. 2010. BAMBI (bone morphogenetic protein and activin membrane-bound inhibitor) reveals the involvement of the transforming growth factor- $\beta$ family in pain modulation. J Neurosci 30: 1502-1511.

Trombly DJ, Woodruff TK, Mayo KE. 2009. Roles for transforming growth factor $\beta$ superfamily proteins in early folliculogenesis. Semin Reprod Med 27: 14-23.

Tsang M, Kim R, de Caestecker MP, Kudoh T, Roberts AB, Dawid IB. 2000. Zebrafish nma is involved in TGF $\beta$ family signaling. Genesis 28: 47-57.

Tsuchida K, Arai KY, Kuramoto Y, Yamakawa N, Hasegawa Y, Sugino H. 2000. Identification and characterization of a novel follistatin-like protein as a binding protein for the TGF- $\beta$ family. J Biol Chem 275: 40788-40796.

Tsuchida K, Nakatani M, Yamakawa N, Hashimoto O, Hasegawa Y, Sugino H. 2004. Activin isoforms signal through type I receptor serine/threonine kinase ALK7. Mol Cell Endocrinol 220: 59-65.

Tsurutani Y, Fujimoto M, Takemoto M, Irisuna H, Koshizaka M, Onishi S, Ishikawa T, Mezawa M, He P, Honjo S, et al. 2011. The roles of transforming growth factor- $\beta$ and Smad3 signaling in adipocyte differentiation and obesity. Biochem Biophys Res Commun 407: 68-73.

Ueno N, Ling N, Ying SY, Esch F, Shimasaki S, Guillemin R. 1987. Isolation and partial characterization of follistatin: A single-chain Mr 35,000 monomeric protein that inhibits the release of follicle-stimulating hormone. Proc Natl Acad Sci 84: 8282-8286.

Ushiro Y, Hashimoto O, Seki M, Hachiya A, Shoji H, Hasegawa Y. 2006. Analysis of the function of activin $\beta C$ subunit using recombinant protein. J Reprod Dev 52: 487495.

Vale W, Rivier J, Vaughan J, McClintock R, Corrigan A, Woo W, Karr D, Spiess J. 1986. Purification and characterization of an FSH releasing protein from porcine ovarian follicular fluid. Nature 321: 776-779.

Vale W, Bilezikjian LM, Rivier C. 1994. Reproductive and other roles of inhibins and activins. In The physiology of reproduction (ed. Knobil E, Neill JD, Greenswald GS, Markert CL, Pfaff DW), pp. 1861-1878. Raven, New York.

Varelas X, Sakuma R, Samavarchi-Tehrani P, Peerani R, Rao BM, Dembowy J, Yaffe MB, Zandstra PW, Wrana JL. 2008 TAZ controls Smad nucleocytoplasmic shuttling and regulates human embryonic stem-cell self-renewal. Nat Cell Biol 10: $837-848$. 
Vassalli A, Matzuk MM, Gardner HA, Lee KF, Jaenisch R. 1994. Activin/inhibin $\beta B$ subunit gene disruption leads to defects in eyelid development and female reproduction. Genes Dev 8: 414-427.

Vejda S, Cranfield M, Peter B, Mellor SL, Groome N, Schulte-Hermann R, Rossmanith W. 2002. Expression and dimerization of the rat activin subunits $\beta C$ and $\beta E$ : Evidence for the ormation of novel activin dimers. $J$ Mol Endocrinol 28: 137-148.

Vural F, Vural B, Yucesoy I, Badur S. 2005. Ovarian aging and bone metabolism in menstruating women aged 35-50 years. Maturitas 52: 147-153.

Wada W, Kuwano H, Hasegawa Y, Kojima I. 2004. The dependence of transforming growth factor- $\beta$-induced collagen production on autocrine factor Activin $\mathrm{A}$ in hepatic stellate cells. Endocrinology 145: 2753-2759.

Wada W, Medina J, Hasegawa Y, Kuwano H, Kojima I. 2005. Adenovirus-mediated overexpression of the activin $\beta C$ subunit accelerates liver regeneration in partially hepatectomized rats. J Hepatol 43: 823-828.

Wahl M. 2013. UPDATE: ACE-031 clinical trials in Duchenne MD. In Quest. Muscular Dystrophy Association, Chicago.

Wakefield LM, Hill CS. 2013. Beyond TGF $\beta$ : Roles of other TGF $\beta$ superfamily members in cancer. Nat Rev Cancer 13: $328-341$.

Waldrip WR, Bikoff EK, Hoodless PA, Wrana JL, Robertson EJ. 1998. Smad2 signaling in extraembryonic tissues determines anterior-posterior polarity of the early mouse embryo. Cell 92: 797-808.

Walton KL, Makanji Y, Wilce MC, Chan KL, Robertson DM, Harrison CA. 2009. A common biosynthetic pathway governs the dimerization and secretion of inhibin and related transforming growth factor $\beta$ (TGF $\beta$ ) ligands. J Biol Chem 284: 9311-9320.

Walton KL, Makanji Y, Harrison CA. 2012. New insights into the mechanisms of activin action and inhibition. Mol Cell Endocrinol 359: 2-12.

Wang QF, Farnworth PG, Findlay JK, Burger HG. 1988. Effect of purified $31 \mathrm{~K}$ bovine inhibin on the specific binding of gonadotropin-releasing hormone to rat anterior pituitary cells in culture. Endocrinology 123: 2161 2166.

Wankell M, Kaesler S, Zhang YQ, Florence C, Werner S, Duan R. 2001a. The activin binding proteins follistatin and follistatin-related protein are differentially regulated in vitro and during cutaneous wound repair. J Endocrinol 171: 385-395.

Wankell M, Munz B, Hübner G, Hans W, Wolf E, Goppelt A, Werner S. 2001b. Impaired wound healing in transgenic mice overexpressing the activin antagonist follistatin in the epidermis. EMBO J 20: 5361-5372.

Weisberg SP, McCann D, Desai M, Rosenbaum M, Leibel RL, Ferrante AW Jr. 2003. Obesity is associated with macrophage accumulation in adipose tissue. J Clin Invest 112: $1796-1808$.

Welt CK. 2004. Regulation and function of inhibins in the normal menstrual cycle. Semin Reprod Med 22: 187-193.

Welt CK, Schneyer AL. 2001. Differential regulation of inhibin $\mathrm{B}$ and inhibin a by follicle-stimulating hormone and local growth factors in human granulosa cells from small antral follicles. J Clin Endocrinol Metab 86: 330336.

Werner S, Alzheimer C. 2006. Roles of activin in tissue repair, fibrosis, and inflammatory disease. Cytokine Growth Factor Rev 17: 157-171.

Wiater E, Vale W. 2012. Roles of activin family in pancreatic development and homeostasis. Mol Cell Endocrinol 359: 23-29.

Wiater E, Lewis KA, Donaldson C, Vaughan J, Bilezikjian L, Vale W. 2009. Endogenous betaglycan is essential for high-potency inhibin antagonism in gonadotropes. $\mathrm{Mol}$ Endocrinol 23: 1033-1042.

Winer S, Chan Y, Paltser G, Truong D, Tsui H, Bahrami J, Dorfman R, Wang Y, Zielenski J, Mastronardi F, et al. 2009. Normalization of obesity-associated insulin resistance through immunotherapy. Nat Med 15: 921-929.

Winters SJ, Pohl CR, Adedoyin A, Marshall GR. 1996. Effects of continuous inhibin administration on gonadotropin secretion and subunit gene expression in immature and adult male rats. Biol Reprod 55: 1377-1382.

Woodruff TK, D’Agostino J, Schwartz NB, Mayo KE. 1988. Dynamic changes in inhibin messenger RNAs in rat ovarian follicles during the reproductive cycle. Science 239: 1296-1299.

Woodruff TK, Lyon RJ, Hansen SE, Rice GC, Mather JP. 1990. Inhibin and activin locally regulate rat ovarian folliculogenesis. Endocrinology 127: 3196-3205.

Woodruff TK, Krummen L, Chen SA, Lyon R, Hansen SE, DeGuzman G, Covello R, Mather J, Cossum P. 1993a. Pharmacokinetic profile of recombinant human ( $\mathrm{rh}$ ) inhibin $\mathrm{A}$ and activin $\mathrm{A}$ in the immature rat. II: Tissue distribution of $\left[{ }^{125} \mathrm{I}\right] \mathrm{rh}$-inhibin $\mathrm{A}$ and $\left[{ }^{125} \mathrm{I}\right] \mathrm{rh}$-activin A in immature female and male rats. Endocrinology 132: $725-734$.

Woodruff TK, Krummen L, McCray G, Mather JP. 1993b. In situ ligand binding of recombinant human $\left[{ }^{125} \mathrm{I}\right]$ activin$\mathrm{A}$ and recombinant human $\left[{ }^{125} \mathrm{I}\right]$ inhibin-A to the adult rat ovary. Endocrinology 133: 2998-3006.

Woodruff TK, Krummen LA, Chen S, DeGuzman G, Lyon R, Baly DL, Allison DE, Garg S, Wong WL, Hebert N, et al. 1993c. Pharmacokinetic profile of recombinant human (rh) inhibin A and activin $\mathrm{A}$ in the immature rat. I: Serum profile of rh-inhibin A and rh-activin A in the immature female rat. Endocrinology 132: 715-724.

Woodruff TK, Besecke LM, Groome N, Draper LB, Schwartz NB, Weiss J. 1996. Inhibin A and inhibin B are inversely correlated to follicle-stimulating hormone, yet are discordant during the follicular phase of the rat estrous cycle, and inhibin A is expressed in a sexually dimorphic manner. Endocrinology 137: 5463-5467.

Wrathall JH, Knight PG. 1995. Effects of inhibin-related peptides and oestradiol on androstenedione and progesterone secretion by bovine theca cells in vitro. J Endocrinol 145: 491-500.

Wu DD, Lai M, Hughes PE, Sirimanne E, Gluckman PD, Williams CE. 1999. Expression of the activin axis and neuronal rescue effects of recombinant activin A following hypoxic-ischemic brain injury in the infant rat. Brain Res 835: 369-378.

Wu X, Chen L, Brown CA, Yan C, Matzuk MM. 2004. Interrelationship of growth differentiation factor 9 and in- 
hibin in early folliculogenesis and ovarian tumorigenesis in mice. Mol Endocrinol 18: 1509-1519.

Wu H, Ghosh S, Perrard XD, Feng L, Garcia GE, Perrard JL, Sweeney JF, Peterson LE, Chan L, Smith CW, et al. 2007. T-cell accumulation and regulated on activation, normal $\mathrm{T}$ cell expressed and secreted upregulation in adipose tissue in obesity. Circulation 115: 1029-1038.

Wu Z, Zhang W, Chen G, Cheng L, Liao J, Jia N, Gao Y, Dai H, Yuan J, Cheng L, et al. 2008. Combinatorial signals of activin/nodal and bone morphogenic protein regulate the early lineage segregation of human embryonic stem cells. J Biol Chem 283: 24991-25002.

Wu H, Chen Y, Winnall WR, Phillips DJ, Hedger MP. 2012. Acute regulation of activin $\mathrm{A}$ and its binding protein, follistatin, in serum and tissues following lipopolysaccharide treatment of adult male mice. Am J Physiol Regul Integr Comp Physiol 303: R665-R675.

Wu H, Wu M, Chen Y, Allan CA, Phillips DJ, Hedger MP. 2013. Correlation between blood activin levels and clinical parameters of type 2 diabetes. Exp Diabetes Res 2012: 410579.

Wu H, Mezghenna K, Marmol P, Guo T, Moliner A, Yang S-N, Berggren P-O, Ibáñez CF. 2014. Differential regulation of mouse pancreatic islet insulin secretion and Smad proteins by activin ligands. Diabetologia 57: 148-156.

Xia Y, Sidis Y, Schneyer A. 2004. Overexpression of follistatin-like 3 in gonads causes defects in gonadal development and function in transgenic mice. Mol Endocrinol 18: 979-994.

Xie L, Ortega MT, Mora S, Chapes SK. 2010. Interactive changes between macrophages and adipocytes. Clin $\mathrm{Vac}$ cine Immunol 17: 651-659.

Xu RH, Sampsell-Barron TL, Gu F, Root S, Peck RM, Pan G, Yu J, Antosiewicz-Bourget J, Tian S, Stewart R, et al. 2008 NANOG is a direct target of TGF $\beta /$ activin-mediated SMAD signaling in human ESCs. Cell Stem Cell 3: 196-206.

Yadav H, Quijano C, Kamaraju AK, Gavrilova O, Malek R, Chen W, Zerfas P, Zhigang D, Wright EC, Stuelten C, et al. 2011. Protection from obesity and diabetes by blockade of TGF- $\beta /$ Smad3 signaling. Cell Metab 14: 67-79.

Yamada Y, Yamamoto H, Yonehara T, Kanasaki H, Nakanishi H, Miyamoto E, Miyazaki K. 2004. Differential activation of the luteinizing hormone $\beta$-subunit promoter by activin and gonadotropin-releasing hormone: A role for the mitogen-activated protein kinase signaling pathway in LßT2 gonadotrophs. Biol Reprod 70: 236-243.

Yamaoka T, Idehara C, Yano M, Matsushita T, Yamada T, Ii S, Moritani M, Hata J, Sugino H, Noji S, et al. 1998. Hypoplasia of pancreatic islets in transgenic mice expressing activin receptor mutants. J Clin Invest 102: 294-301.

Yamashita S, Maeshima A, Kojima I, Nojima Y. 2004. Activin $\mathrm{A}$ is a potent activator of renal interstitial fibroblasts. JAm Soc Nephrol 15: 91-101.

Yang X, Letterio JJ, Lechleider RJ, Chen L, Hayman R, Gu H, Roberts AB, Deng C. 1999. Targeted disruption of SMAD3 results in impaired mucosal immunity and diminished T cell responsiveness to TGF- $\beta$. EMBO J 18: 1280-1291.

Yao HH, Matzuk MM, Jorgez CJ, Menke DB, Page DC, Swain A, Capel B. 2004. Follistatin operates downstream of Wnt4 in mammalian ovary organogenesis. Dev Dyn 230: $210-215$.

Yao HH, Aardema J, Holthusen K. 2006. Sexually dimorphic regulation of inhibin $\beta B$ in establishing gonadal vasculature in mice. Biol Reprod 74: 978-983.

Yasuda H, Inoue K, Shibata H, Takeuchi T, Eto Y, Hasegawa Y, Sekine N, Totsuka Y, Mine T, Ogata E, et al. 1993. Existence of activin-A in A- and D-cells of rat pancreatic islet. Endocrinology 133: 624-630.

Yu J, Shao LE, Lemas V, Yu AL, Vaughan J, Rivier J, Vale W. 1987. Importance of FSH-releasing protein and inhibin in erythrodifferentiation. Nature 330: 765-767.

Zaragosi LE, Wdziekonski B, Villageois P, Keophiphath M, Maumus M, Tchkonia T, Bourlier V, Mohsen-Kanson T, Ladoux A, Elabd C, et al. 2010. Activin A plays a critical role in proliferation and differentiation of human adipose progenitors. Diabetes 59: 2513-2521.

Zhang YQ, Shibata H, Schrewe H, Kojima I. 1997. Reciprocal expression of mRNA for inhibin $\beta C$ and $\beta A$ subunits in hepatocytes. Endocr J 44: 759-764.

Zhang YQ, Zhang H, Maeshima A, Kurihara H, Miyagawa J, Takeuchi T, Kojima I. 2002. Up-regulation of the expression of activins in the pancreatic duct by reduction of the $\beta$-cell mass. Endocrinology 143: 3540-3547.

Zhang YQ, Cleary MM, Si Y, Liu G, Eto Y, Kritzik M, Dabernat S, Kayali AG, Sarvetnick N. 2004. Inhibition of activin signaling induces pancreatic epithelial cell expansion and diminishes terminal differentiation of pancreatic $\beta$-cells. Diabetes 53: 2024-2033.

Zhang L, Deng M, Parthasarathy R, Wang L, Mongan M, Molkentin JD, Zheng Y, Xia Y. 2005. MEKK1 transduces activin signals in keratinocytes to induce actin stress fiber formation and migration. Mol Cell Biol 25: 60-65.

Zhang M, Liu NY, Wang XE, Chen YH, Li QL, Lu KR, Sun L, Jia Q, Zhang L. 2011. Activin B promotes epithelial wound healing in vivo through RhoA-JNK signaling pathway. PLOS ONE 6: e25143.

Zhang C, McFarlane C, Lokireddy S, Masuda S, Ge X, Gluckman PD, Sharma M, Kambadur R. 2012. Inhibition of myostatin protects against diet-induced obesity by enhancing fatty acid oxidation and promoting a brown adipose phenotype in mice. Diabetologia 55: 183-193.

Zhang Y, Zhang DY, Zhao YF, Wang J, He JW, Luo J. 2013. Analysis and characterization of the functional TGF $\beta$ receptors required for BMP6-induced osteogenic differentiation of mesenchymal progenitor cells. BMB Rep 46: $107-112$.

Zhao F, Huang F, Tang M, Li X, Zhang N, Amfilochiadis A, Li Y, Hu R, Jin T, Peng C, et al. 2012. Nodal induces apoptosis through activation of the ALK7 signaling pathway in pancreatic INS-1 $\beta$-cells. Am J Physiol Endocrinol Metab 303: E132-E143.

Zheng X, Wang J, Haerry TE, Wu AY, Martin J, O'Connor MB, Lee $\mathrm{CH}$, Lee T. 2003. TGF- $\beta$ signaling activates steroid hormone receptor expression during neuronal remodeling in the Drosophila brain. Cell 112: 303-315.

Zheng X, Zugates CT, Lu Z, Shi L, Bai JM, Lee T. 2006. Baboon/dSmad2 TGF- $\beta$ signaling is required during late larval stage for development of adult-specific neurons. EMBO J 25: 615-627. 
Zhou X, Wang JL, Lu J, Song Y, Kwak KS, Jiao Q, Rosenfeld R, Chen Q, Boone T, Simonet WS, et al. 2010. Reversal of cancer cachexia and muscle wasting by ActRIIB antagonism leads to prolonged survival. Cell 142: 531-543.

Zhu Y, Richardson JA, Parada LF, Graff JM. 1998. Smad3 mutant mice develop metastatic colorectal cancer. Cell 94: 703-714.

Zhu CC, Boone JQ, Jensen PA, Hanna S, Podemski L, Locke J, Doe CQ, O'Connor MB. 2008. Drosophila Activin- and the Activin-like product Dawdle function redundantly to regulate proliferation in the larval brain. Development 135: 513-521.

Zhu J, Braun EL, Kohno S, Antenos M, Xu EY, Cook RW, Lin SJ, Moore BC, Guillette LJ Jr, Jardetzky TS, et al. 2010. Phylogenomic analyses reveal the evolutionary origin of the inhibin $\alpha$-subunit, a unique TGF $\beta$ superfamily antagonist. PLoS ONE 5: e9457.

Zhu J, Lin SJ, Zou C, Makanji Y, Jardetzky TS, Woodruff TK. 2012. Inhibin $\alpha$-subunit $\mathrm{N}$ terminus interacts with activin type IB receptor to disrupt activin signaling. J Biol Chem 287: 8060-8070. 


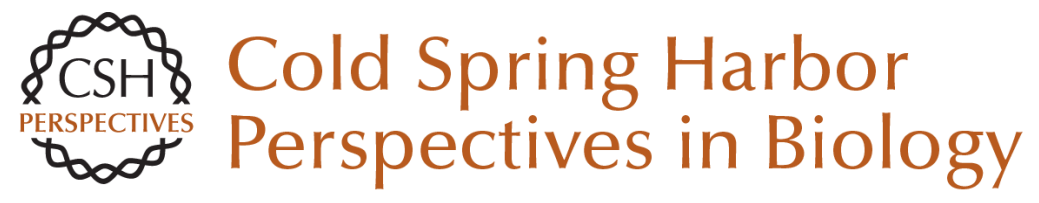

\section{Activins and Inhibins: Roles in Development, Physiology, and Disease}

Maria Namwanje and Chester W. Brown

Cold Spring Harb Perspect Biol 2016; doi: 10.1101/cshperspect.a021881 originally published online June 21, 2016

Subject Collection The Biology of the TGF-\&\#946; Family

TGF- $\beta$ Family Signaling in Early Vertebrate Development Joseph Zinski, Benjamin Tajer and Mary C. Mullins

Bone Morphogenetic Protein-Based Therapeutic Approaches Jonathan W. Lowery and Vicki Rosen

TGF- $\beta$ Family Signaling in Ductal Differentiation and Branching Morphogenesis

Kaoru Kahata, Varun Maturi and Aristidis Moustakas

TGF- $\beta$ Signaling in Control of Cardiovascular

Function

Marie-José Goumans and Peter ten Dijke

TGF- $\beta$ Family Signaling in Tumor Suppression and Cancer Progression

Joan Seoane and Roger R. Gomis

Targeting TGF- $\beta$ Signaling for Therapeutic Gain Rosemary J. Akhurst

Regulation of Hematopoiesis and Hematological Disease by TGF- $\beta$ Family Signaling Molecules Kazuhito Naka and Atsushi Hirao
TGF- $\beta$ Family Signaling in Mesenchymal

Differentiation

Ingo Grafe, Stefanie Alexander, Jonathan $R$. Peterson, et al.

TGF- $\beta 1$ Signaling and Tissue Fibrosis Kevin K. Kim, Dean Sheppard and Harold A. Chapman

Bone Morphogenetic Proteins in Vascular

Homeostasis and Disease Marie-José Goumans, An Zwijsen, Peter ten Dijke, et al.

TGF- $\beta$ Family Signaling in Epithelial

Differentiation and Epithelial-Mesenchymal

Transition

Kaoru Kahata, Mahsa Shahidi Dadras and Aristidis Moustakas

TGF- $\beta$ Family Signaling in Connective Tissue and

Skeletal Diseases

Elena Gallo MacFarlane, Julia Haupt, Harry C. Dietz, et al.

The TGF- $\beta$ Family in the Reproductive Tract Diana Monsivais, Martin M. Matzuk and Stephanie A. Pangas

TGF- $\beta$ Family Signaling in Drosophila Ambuj Upadhyay, Lindsay Moss-Taylor, Myung-Jun Kim, et al.

For additional articles in this collection, see http://cshperspectives.cshlp.org/cgi/collection/

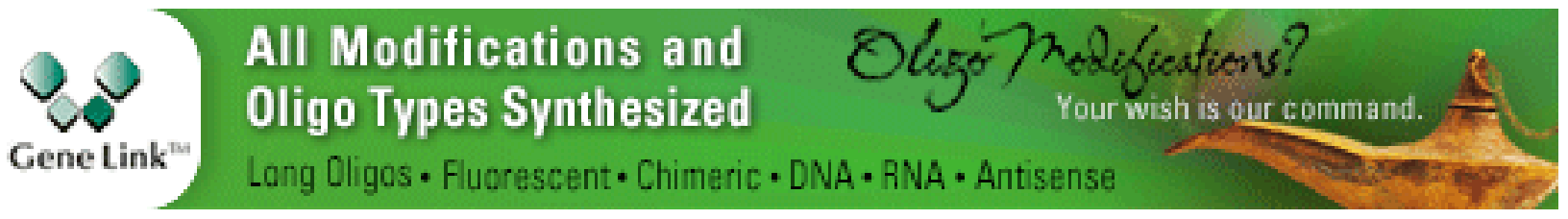


TGF- $\beta$ Family Signaling in Neural and Neuronal Differentiation, Development, and Function Emily A. Meyers and John A. Kessler
Signaling Cross Talk between TGF- $\beta /$ Smad and Other Signaling Pathways Kunxin LuO

For additional articles in this collection, see http://cshperspectives.cshlp.org/cgi/collection/

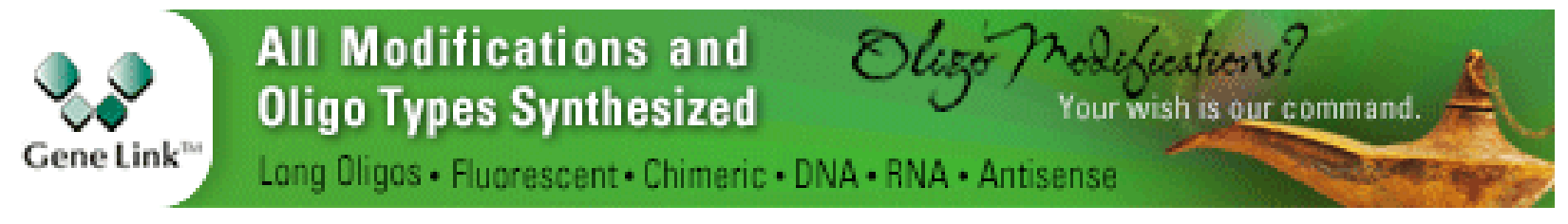

Copyright @ 2016 Cold Spring Harbor Laboratory Press; all rights reserved 